
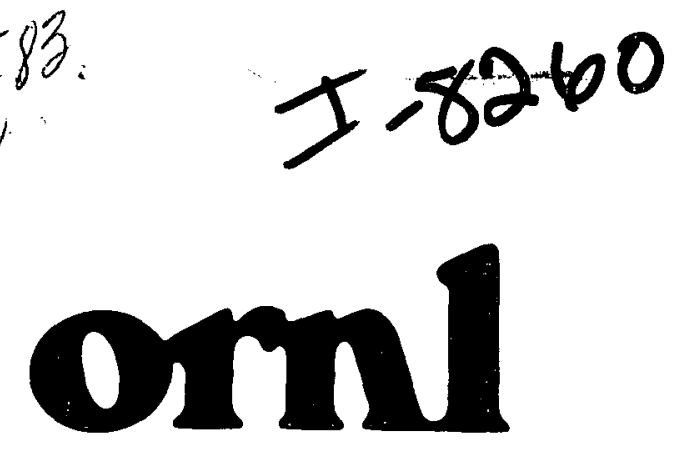

OAK

RIDGE

NATIONAL

LABORATORY

UNION

CARBIDE

\title{
Wilderness Designation of Bureau of Land Management Lands and Impacts on the Availability of Energy Resources
}
E. H. Oakes
A. H. Voelker

OPERATED BY

UNION CARBIDE CORPORATION FOR THE UNITED STATES DEPARTMENT OF ENERGY

\section{MASTER}




\section{DISCLAIMER}

This report was prepared as an account of work sponsored by an agency of the United States Government. Neither the United States Government nor any agency Thereof, nor any of their employees, makes any warranty, express or implied, or assumes any legal liability or responsibility for the accuracy, completeness, or usefulness of any information, apparatus, product, or process disclosed, or represents that its use would not infringe privately owned rights. Reference herein to any specific commercial product, process, or service by trade name, trademark, manufacturer, or otherwise does not necessarily constitute or imply its endorsement, recommendation, or favoring by the United States Government or any agency thereof. The views and opinions of authors expressed herein do not necessarily state or reflect those of the United States Government or any agency thereof. 


\section{DISCLAIMER}

Portions of this document may be illegible in electronic image products. Images are produced from the best available original document. 
Printed in the United States of America. Available from National Technical Information Service

U.S. Department of Commerce

5285 Port Royal Road, Springfield, Virginia 22161

NTIS price codes-Printed Copy: A06 Microfiche A01

This report was prepared as an account of work sponsored by an agency of the United States Government. Neither the United States Governmerit nor any agency thereof, nor any of their employees, makes any warranty, express or implied, or assumes any legal liability or responsibility for the accuracy, completeness, or usefulness of any information, apparatus, product, or process disclosed, or represents that its use would not infringe privately owned rights. Reference herein to any specific commercial product, process, or service by trade name, trademark, manufacturer, or otherwise, does not necessarily constitute or imply its endorsement, recommendation, or favoring by the United States Government or any agency thereof. The views and opinions of authors expressed herein do not necessarily state or reflect those of the United States Government or any agency thereof. 


\title{
MILDERNESS DESIGLATION OF BURBAD OF LAND MAKAGEMENT LANDS ARD IMPACTS ON THE AVAIĹABILITY OF EIKRRGY RESOURCES
}

\author{
B. H. Oakes \\ Science Applications, Inc. \\ and
}

\author{
A. H. Voelker \\ Bnergy Division \\ Oak RIdge National Laboratory
}

Date Published - February 1983

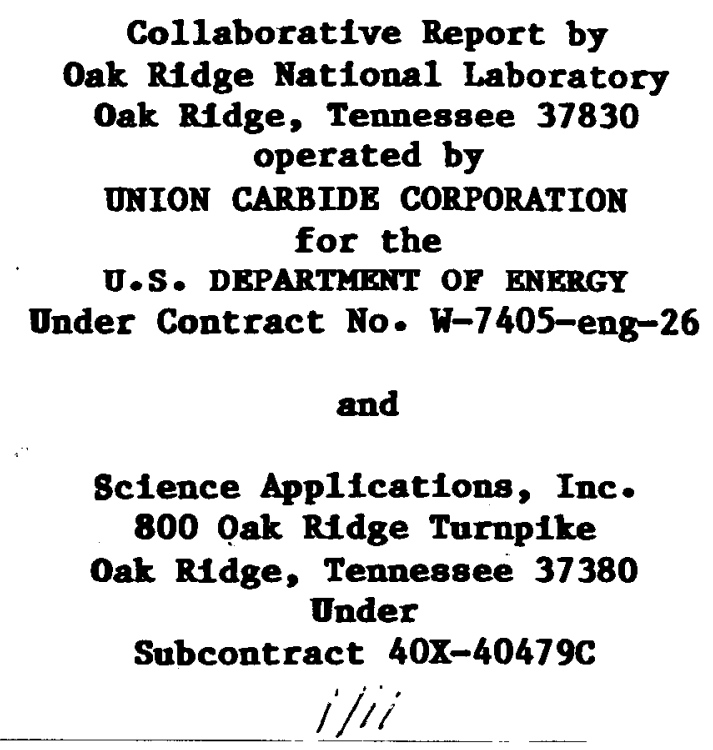

DISCLAIMER

This report was prepared as an account of work sponsored by an agency of the United States Government. Neither the United States Government nor any agency thereof, nor any of their employees, makes any warranty, express or implied, or assumes any legal liability or responsibility for the accuracy, completeness, or usefulness of any information, apparatus, product, or process disclosed, or represents that its use would not infringe privately owned rights. Reference herein to any specific commercial product, process, or service by trade name, trademark, manufacturer, or otherwise does not necessarily constitute or imply its endorsement, recommendation, or favoring by the United States Government or any agency thereof. The views and opinions of authors expressed herein do not necessarily state or reflect those of the United States Government or any agency thereof. 

.

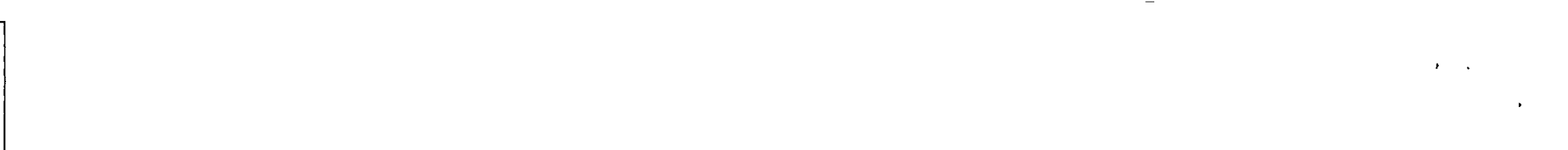

the 


\section{CONTENTS}

Page

LIST OF FIGURES . . . . . . . . . . . . . . . . . . . V v

LIST OF TABLES . . . . . . . . . . . . . . . . . . . . vi vi

CONVERSION CHART OF ENGLISH TO SI UNITS . . . . . . . . . . . . viii

ABSTRACT . . . . . . . . . . . . . . . . . . . . . 1

SUMMARY AND RECOMMENDATIONS . . . . . . . . . . . . . . 2

INTRODUCTION . . . . . . . . . . . . . . . . 12

BLM's WILDERNESS REVIEW PROGRAM . . . . . . . . . . . . 12

PURPOSE OF THIS DOE STUDY ................ 13

SCOPE OF STUDY .................... 14

Part 1. ENERGY RESOURCES, RESERVES, AND PRODUCTION

IN THE WESTERN UNITED STATES AND THE ROLE

OF WESTERN FEDERAL ONSHORE LANDS . . . . . . . . 16

INTRODUCTION ................... 16

METHOD OF STUDY ................... 17

OIL AND GAS . . . . . . . . . . . . . . . . . 18

URANIUM . . . . . . . . . . . . . . . . . . . 24

COAL . . . . . . . . . . . . . . . . . . 27

GEOTHERMAL . . . . . . . . . . . . . . . . . . 30

HYDROELECTRIC POWER .................... 32

SUMMARY AND CONCLUSIONS ................. 34

Part 2. DESIGNATION OF BLM WILDERNESS AND POTENTIAL IMPACTS

ON THE FUTURE AVAILABILITY OF ENERGY RESOURCES . . . . 37

INTRODUCTION . . . . . . . . . . . . . . . 37

DISTRIBUTION OF WSAS IN THE WESTERN UNITED STATES . . . . 38

NOTE OF CAUTION . . . . . . . . . . . . . . . . . 40

COINCIDENCE BETWEEN WSAS AND AREAS OF IMPORTANT

OIL AND GAS POTENTIAL ................... . . . 40

Quantitative Estimates . . . . . . . . . . 42 
COINCIDENCE BETWEEN WSAS AND AREAS OF IMPORTANT

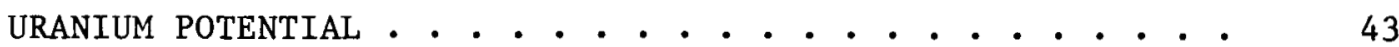

Quantitative Estimates . . . . . . . . . . . 45

COINCIDENCE BETWEEN WSAS AND AREAS OF COAL RE'SERVES . . . . 46

Quantitative Estimates . . . . . . . . . . . . . . 48

COINCIDENCE BETWEEN WSAS AND AREAS OF IMPORTANT

GEOTHERMAL RESOURCES . . . . . . . . . . . . . . . . 50

Quantitative Estimates . . . . . . . . . . . . 50

COINCIDENCE BETWEEN WSAS AND AREAS OF HYDROELECTRIC

POWER RESOURCES . . . . . . . . . . . . . . . . . . . . . . . . . . . . . 52

SUMMARY . . . . . . . . . . . . . . . . . . . • • 53

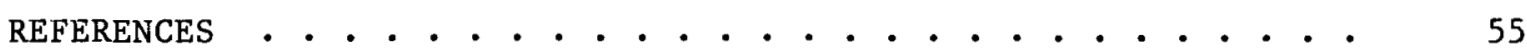

Appendix. CURRENT AND FUTURE AVAILABILITY OF FEDERAL

ONSHORE LANDS IN THE WESTERN UNITED STATES

FOR MINERAL ACTIVITY . . . . • . . . . • . . . . 57

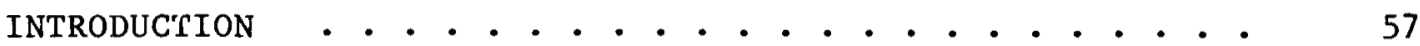

SCOPE AND METHOD OF STUDY • • • • • • • • • • • • • • • . . 58

FEDERAL LANDS IN THE WEST AND THE MINERAL LAWS . • • . . . 59

PREVIOUS AND CURRENT STUDIES ON THE AVAILABILITY OF

FEDERAL LANDS FOR MINERAL ACTIVITIES • • • • • • • • • . . 61

USE IN THIS STUDY OF THE TERMS WITHDRAWAL, EFFECTIVELY

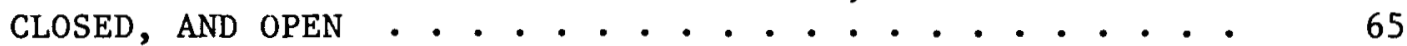

THE PROBLEM OF OVERLAPPING AND ADMINISTRATIVE

WITHDRAWALS . . . . . . . . . . . . . . . . . . . . . 68

RESULTS • . . . . . . . . . . . . . . . . . . . . . . • 70

CONCLUSIONS AND RECOMMENDATIONS . . . . . . . . . . . . . 89

REFERENCES FOR APPENDIX • • • • • • • • • • • • • • • . . 90 


\section{LIST OF FIGURES}

Figure

Page

1 Regions Recommended to the BLM for Accelerated Studies of WSA Suitability . . . . . . . . . . . . . . . 9

2 U.S. Supply of Energy and Energy Resources, and the Role of Western Federal Onshore Lands . . . . . . . . . . 35

3 The Distribution of WSAs in the 11 Western States . . . . . 39

4 The Coincidence Between WSAs and Areas of High to Moderate Potential for $0 i 1$ and Gas . . . . . . . . . . . . . 41

5 The Coincidence Between WSAs and Areas of High to Moderate Potential for Uranium . . . . . . . . . . . . . . . . 44

6 The Coincidence Between WSAs and Areas of High to Moderate Potential for Coal Development . . . . . . . . . . . 47

7 The Coincidence Between WSAs and Areas of Geothermal Resources ............ 51 


\section{LIST OF TABLES}

\section{Table}

Page

1 Energy-Resource Potential of Western Federal Onshore Lands . . . . . . . . . . . . . 5

2 Energy-Resource Potential of WSAs in the West . . . . . . 7

3 Comparison of Oil Production, Reserves, and Resources in the United States, the 11 Western States, and Western Federal Onshore Lands . . . . . . . . . . . . . .

4 Comparison of Natual Gas Production, Reserves, and Resources in the United States, the 11 Western States, and Western Federal Onshore Lands . . . . . . . . . . . . . .

5 Comparison of Uranium Oxide Production, Reserves, and Resources in the United States, the 11 Western States, and Western Federal Lands . . . . . . . . .

6 Comparison of Coal Production and Demonstrated Reserves in the United States, the 11 Western States, and Western Federal Lands . . . . . . . . . . . . . . . . . .

7 Comparison of Geothermal Energy Production, Identified Resources, and Undiscovered Resources in the United States, the 11 Western States, and Western Federal Lands . .

8 Comparison of Hydroelectric Power Production and Potential (at Identified Sites) in the United States, the 11 Western States, and Western Federal Lands .. . . . . 33

9 Tonnage of Uranium Allotted to Wilderness Study Areas. . . . . 46

10 Energy-Resource Potential of WSAs in the West . . . . . . . 54

A.1 Acreage of Federal Lands in the United States and the West as of 1979 . . . . . . . . . . . . . .

A.2 Results of Previous and Current Studies of Federal-Land Availability for Mineral Activities . . . . . . . . 
A.3 Availability of Federal Onshore Lands in the Western United States for Leasable Minerals as of 1981 . . . . . . 72

A.4 Availability of Federal Onshore Lands in the Western United States for Locatable Minerals as of 1981 . . . . .

A.5 Estimated Future (1990) Availability of Onshore Federa1 Lands in the Western United States for Mineral Activities 


\section{CONVERSION CHART OF ENGLISH TO SI UNITS}

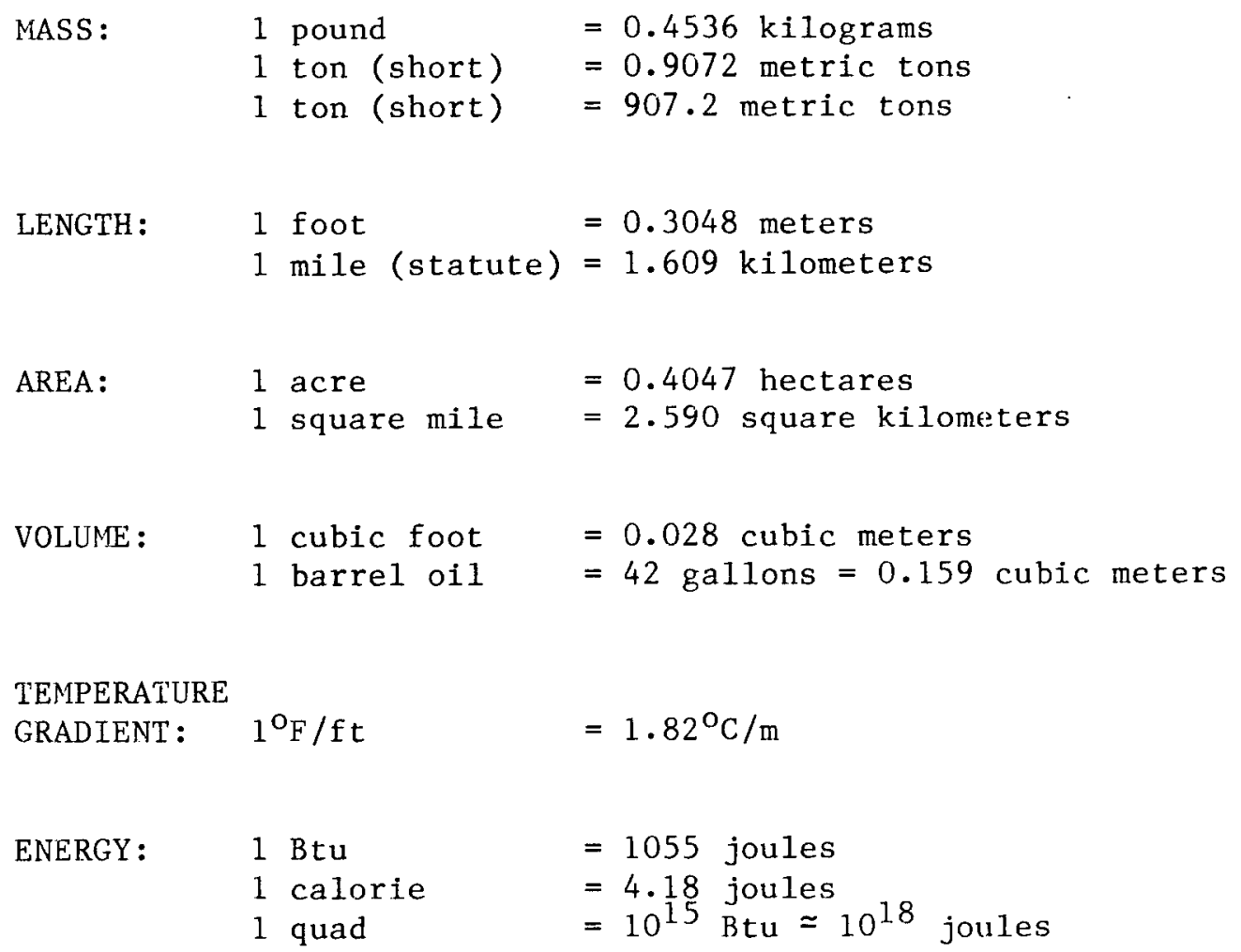

HEAT FLOW: 1 heat flow unit $=41.8$ milliwatts per: square meter (HFU) 


\title{
WILDERNESS DESIGNATION OF BUREAU OF LAND MANAGEMENT LANDS AND IMPACTS ON THE AVAILABILITY OF ENERGY RESOURCES
}

\author{
E. H. Oakes \\ Science Applications, Inc. \\ and \\ A. H. Voelker \\ Energy Division \\ Oak Ridge Nationa1 Laboratory
}

\begin{abstract}
In 1964 Congress mandated the establishment of the National Wilderness Preservation System--a collection of federal lands dedicated to the preservation of selected parts of our once vast wilderness. Because wilderness management precludes many traditional land uses, controversy has plagued the efforts of land-management agencies to select and recommend areas for wilderness inclusion. This study examines potential impacts on the supply of energy resources from the possible withdrawal by the Bureau of Land Management (BLM) of some part of the 24.3 million acres of public lands now under study for inclusion in the wilderness system. The acreage is in the western United States and is divided into 947 separate tracts of land called "wilderness study areas" (WSAs).

The energy-resource potential of the total acreage of WSAs for oil, gas, uranium, coal, geothermal energy, and hydropower was estimated through a sequence of steps that (1) reported the nation's estimated potential for each energy resource, (2) reported the estimated potential for each energy resource in the western United States, (3) estimated the potential for each energy resource on western federal lands, and (4) estimated the resource potential of the WSAs. Except for uranium, the energy-resource potential of the total WSA-acreage is low. Wilderness designation of some WSAs is therefore not expected to cause serious impacts on the future availability of energy resources.
\end{abstract}

*Research sponsored by the Leasing Policy Division, Office of Fossil Energy, U.S. Department of Energy, under Contract W-7405-eng-26 with the Union Carbide Corporation. 
Although the estimated energy-resource potential of the WSA-acreage is low, these WSAs would be important to the nation if most other federal lands were unavailable for mineral development. Because the significance of land withdrawals by the BLM will depend to some extent on the availability of other federal lands for mineral activities, an up-to-date estimate of the current and future status-of-access to western federal lands for mineral activities was prepared. For the leasable minerals, we estimate that approximately $6 \%$ of the federal lands in the West are formally closed, $38 \%$ are highly restricted, and $56 \%$ are open with moderate or slight (normal) restrictions. For the locatable minerals, we estimate that $14 \%$ of the West's federal lands are closed, $32 \%$ are highly restricted, and $54 \%$ are open with moderate or slight (normal) restrictions. The availability of western federal lands is expected to increase significantly during the next decade, to about $68 \%$ for the leasable minerals and about $67 \%$ for the locatable minerals. These increases are attributed largely to the completion of national land-use planning programs by the major land-management agencies.

Overall conclusions of the report are that (1) the inclusion of some BLM land in the National Wilderness Preservation System will not interfere with the nation's required supply of energy resources, (2) there is sufficient federal land currently available in the West for mineral activities, (3) the availability of western federal land for mineral activities will increase in the future, (4) the administration should continue to support the major land-review programs, and (5) the administration should accelerate the review process for WSAs in regions that have a high energy-resource potential.

\section{SUMMARY AND RECOMMENDATIONS}

The Bureau of Land Management (BLM) currently has 24.3 million acres of public land under wilderness review in the 11 western contiguous States (referred to as the "West" for the remainder of this report, and unless stated otherwise, it does not include offshore areas). The acreage under wilderness review is separated into 947 units, called "wilderness study areas" (WSAs). Altogether, the WSAs represent 3\% of the West's land area, $7 \%$ of the federal lands in the West, and $14 \%$ of the West's BLM-administered lands. By no later than 1991, the BLM must recommend to the Secretary of the Interior those WSAs that should be included in the National Wilderness Preservation System and those that should not. (The FLM's wilderness review progran was halted in Alaska, 
except for areas specifically identified for study in the Alaska National Interest Lands Conservation Act of 1980; WSAs in Alaska were therefore not included in this study.)

This report is designed to answer five questions that are particularly relevant to an overview of the BLM's wilderness review program. These questions are listed below and are answered in the pages that follow.

1. What part of our current domestic supply of energy can be reasonably attributed to energy resources extracted from western federal onshore lands?

2. What is the energy-resource potential of western federal onshore lands?

3. What part of the West's energy-resource potential can be reasonably attributed to WSAs?

4. What regions in the West have a particularly high coincidence between energy-resource potential and WSAs and thereby merit early study in the BLM's wilderness review process?

5. What is the current status of the availability of western federal onshore lands for mineral activities; how does this status affect the realization of the resource potential estimated in questions (2) and (3) above; and what is the estimated status of access to western federal onshore lands in 1990?

Question 1: What part of our current domestic supply of energy can be reasonably attributed to energy resources extracted from western federal onshore lands?

The annual contribution made by western federal onshore lands to our nation's energy supply (in quadrillion Btu, or quads) was estimated for the years 1977, 1978, and 1979 and was then averaged. The analysis indicated that about 8 quads of energy per year could be attributed to these lands during this 3-year period. The nation's average annual supply of energy for this period was 79.8 quads. Thus, western federal onshore lands, which account for $16 \%$ of the total land area of the 
country, contributed about $10 \%$ to the nation's total energy supply. If imports of energy resources (largely oil) are excluded from the nation's energy supply for this period, domestic energy resources supplied an average of 61.4 quads. Of this amount, 8 quads, or 13\%, is attributed to western federal onshore lands. Therefore, on the basis of total domestic production only, federal onshore lands in the lest are now supplying energy resources in an amount roughly proportional to their acreage.

\section{Question 2: What is the energy-resource potential of western federal onshore lands?}

Western federa1 onshore 1ands constitute about $47 \%$ of the total 1 and area of the West. Using recent government reports (generally from 1978 to 1981; see main body of report), we estimated the potential of these lands for the resources evaluated in this study: oil, gas, uranium, coal, geothermal, and hydropower. The results are listed in Table 1. (The term "resources," as used in this table and throughout the report, is defined generally as materials believed to exist on the basis of geologic reasoning, whereas "reserves" are known to exist and can be extracted profitably at the present time.)

As a unit, western federal onshore lands are estimated to contain a larger share of our energy resources (and reserves in the case of coal) than might be expected if one considers that these lands constitute only $16 \%$ of the nation's total land area. We estinate the oil, gas, and hydroelectric potential of these lands to be moderately high and their potential for uranium and geothermal resources to be very high (Table 1). The status of western federal coal is less clear because in many areas the government does not own the surface rights. Therefore, the tonnage 
Table 1. Energy-resource potential of western federal onshore lands ${ }^{a}$

\begin{tabular}{|c|c|c|}
\hline Commodity & Resource potential & $\begin{array}{l}\text { Current contribution of } \\
\text { resource to domestic } \\
\text { energy supply } \\
\text { (Percent of total) }^{b}\end{array}$ \\
\hline 011 & $\begin{array}{l}\text { Up to } 197 \text { of U.S. resources [about } 16 \text { billion } \\
\text { barrels] }\end{array}$ & 29 \\
\hline Gas & $\begin{array}{l}\text { Up to } 17 \% \text { of U.S. resources [about } 100 \text { trillion } \\
\text { cubic feet] }\end{array}$ & 34 \\
\hline Uranium & $\begin{array}{l}\text { 59\% of U.S. resources [about } 2.23 \text { million tons } \\
\text { uranium oxide] }\end{array}$ & 4 \\
\hline CoaI & $\begin{array}{l}327 \text { of U.S. reserves [about } 141 \text { billion tons]. } \\
\text { In many areas of the West containing federal } \\
\text { coal, the government does not own the surface } \\
\text { rights. The tonnage of federal coal under- } \\
\text { lying only those lands in which the federal } \\
\text { government also owns the surface rights is } \\
\text { not known with certainty, but is estimated to } \\
\text { be much less than 50\% of the government's } \\
141 \text { billion tons of western coal. See main } \\
\text { body of report for details. }\end{array}$ & 28 \\
\hline Geothermal & $48 \%$ of U.S. resources [about $1400 \times 10^{18}$ Joules $]^{g}$ & $<1^{h}$ \\
\hline $\begin{array}{l}\text { Hydroelectric } \\
\text { power }\end{array}$ & $21 \%$ of U.S. potentfa1 [about 75,000 megawatts] $^{i}$ & 5 \\
\hline
\end{tabular}

a These lands account for $16 \%$ of the total land area of the country and $12 \%$ of the total onshoreoffshore area assessed recently for oil and gas resources by the U.S. Geological Survey (Dolton et a1. 1981).

$\mathrm{b}_{\mathrm{DOE}}$ (1980a; preliminary 1979 data).

${ }^{c}$ See footnote $c$, Table 3 , for the derivation of the oil estimate.

${ }^{d}$ See footnote $d$, Table 4, for the derivation of the gas estimate.

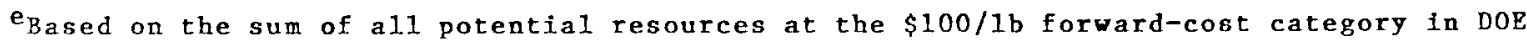
(1980b). See footnote c, Table 5, for the derivation of this estimate.

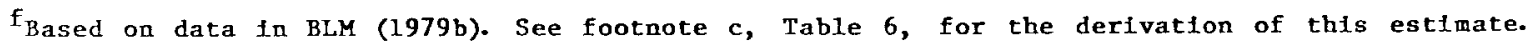
Reserves, rather than resources, are used for coal because this is the category that is commonly cited in the Ifterature for coal estimates (chfefly because much more is known about coal than is knovn about the other energy resources evaluated in this study).

Based on data in Muffler et al. (1978). See footnote c, Table 7, for the derivation of this estimate.

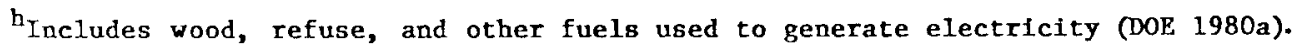

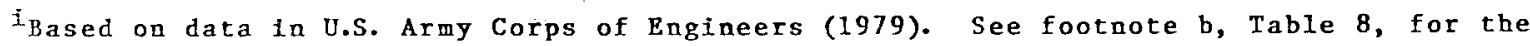
derivation of this estimate. 
of western federal coal that underlies only federal lands is less than the 141 billion tons listed in Table 1. (We estimate the total tonnage to be more than $50 \%$ less; see main body of report.)

The analysis indicates that western federal onshore lands are indeed important as a potential future source of energy resources. Moreover, the proportion of our total energy resources (and energy) supplied by western federal lands is expected to increase during the next few decades as larger amounts of coal, oil, and gas are extracted. On the other hand, large parts of the federal domain in the West have only a minor potential for energy resources. These areas include much of California lying north, east, and south of the petroleum-producing basins in westcentral California; many parts of Nevada; most of Idaho, except the southeastern part; large parts of Arizona; and the interior of many mountain ranges in the Rocky Mountain States.

\section{Question 3: What part of the West's energy-resource potentia1 can be reasonably attributed to WSAs?}

Using available data and the assumptions and estimates made for this analysis (see main body of report), we estimated the energy-resource potential of the $24.3 \mathrm{million}$ acres of WSAs; results are listed in Table 2. Overa11, the WSAs have a somewhat lower energy-resource potential (except for uranium) than would be expected if based solely on the total WSA-acreage.

From a geological standpoint, it is impossible for these resources to be distributed evenly throughout the 24.3 million acres of WSAs. Thus, on $1 y$ some, rather than all, WSAs are important as a potential source of energy resources. (Furthermore, it is reasonable to assume that only a part of the total WSA-acreage will ultimately be included in 
Table 2. Energy-resource potential of WSAs in the West ${ }^{a}$

Commodity

Resource potential

$0.110 .6 \%$ of U.S. resources [about 0.5 billion barrels] ${ }^{\mathrm{b}}$

Gas

$0.4 \%$ of U.S. resources $[2.3 \text { trillion cubic feet }]^{b}$

Uranium

$4.0 \%$ of U.S. resources [0.16 million tons uranium oxide $]^{\mathrm{C}}$

Coa1

$0.7 \%$ of U.S. reserves $[3 \text { billion tons }]^{d}$

Geothermal

No estimate

Hydroelectric

$0.3 \%$ of U.S. potential $\left[1200{\text { megawatts }]^{e}}^{e}\right.$ power

$a_{\text {Total }}$ acreage of WSAs in the West is $24.3 \mathrm{mil1ion}$, which is about $1 \%$ of the total land area of the United States and $7 \%$ of a11 western federal onshore lands.

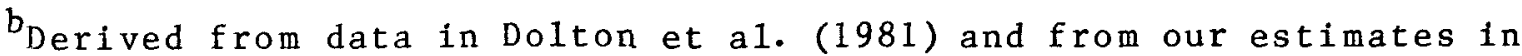
Tables 3 and 4 for oil and gas resources on western federal onshore lands. See body of report for more details.

${ }^{C}$ Derived from data in DOE (1980b) and from our estimates in Table 5 for uranium resources on western federal onshore lands. See body of report for more details.

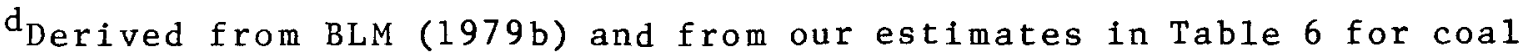
reserves on western federal lands. See body of report for more details.

${ }^{e}$ Derived from data in U.S. Army Corps of Engineers (1979) and from our estimates in Table 8 for identified hydroelectric power resources on western federal lands. See body of report for more details. 
the National Wilderness Preservation System; WSAs not recommended for wilderness will probably become available for multiple-use purposes, including mineral activities.)

Question 4: What regions in the West have a particularly high coincidence between energy-resource potential and WSAs and thereby merit early study in the BLM's review process?

On the basis of the geologic data we reviewed and on the distribution of WSAs in the West, five regions were identified in which an important energy-resource potential coincided with large acreages of WSAs. The five regions, and the energy resources that may occur in them, are illustrated in Figure 1 and are described below. The WSAs in each region merit early study to determine their suitability for wilderness recommendation.

1. Paradox Basin/southeastern Utah. Energy resources include oil, gas, and uranium.

2. Southwestern Wyoming. Energy resources include oil, gas, and uranium.

3. West-central Arizona, southern Nevada, and southeastern California. Energy resources include uranium and a moderate(?) potential for oil and gas.

4. Southeastern Oregon and northwestern Nevada. Energy resources include uranium, geothermal, and a moderate(?) potential for oil and gas.

5. Southwestern Utah and northern Arizona. Energy resources include oil, gas, coal, and uranium.

Question 5: What is the current status of the availability of western federal onshore lands for mineral activities; how does this status affect the realization of the resource potential estimated in questions (2) and (3) above; and what is the estimated status of access to western federal onshore lands in 1990 ?

According to our analysis, about $6 \%$ of the federal onshore lands in the West are now formally closed to mineral leasing, 35\% are highly restricted, and $60 \%$ are open with moderate or slight (normal) 


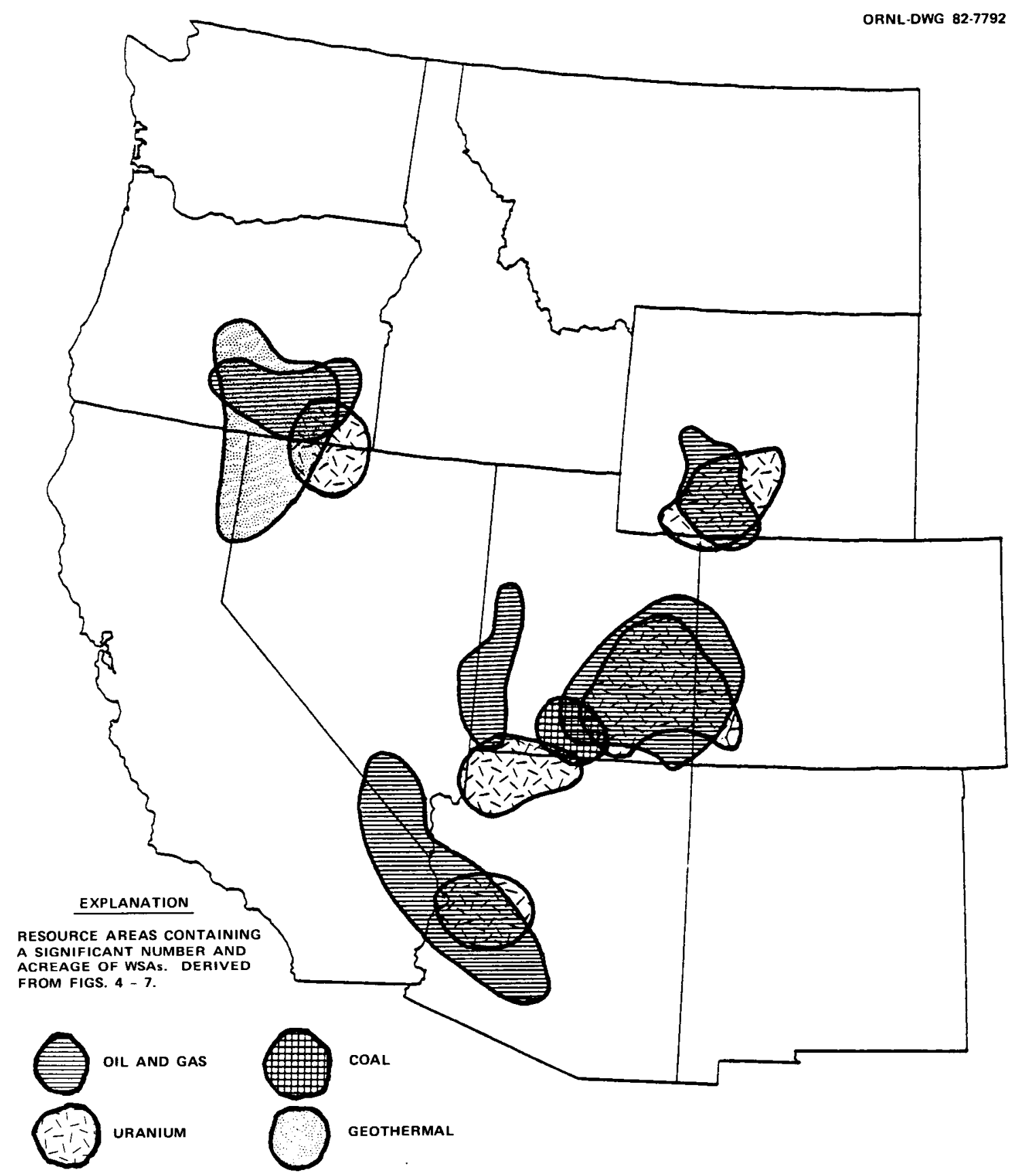

Fig. 1. Regions recommended to the BLM for accelerated WSA suitability studies based on the coincidence of WSAs and areas of important energyresource potential. 
restrictions. For the locatable or "hardrock" minerals, we estimate $14 \%$ of western federal lands to be formally closed, $28 \%$ to be highly restricted, and $58 \%$ to be open with moderate or slight (normal) restrictions. If our estimate of administrative withdrawals is included (called "de facto withdrawa1s" by some), access to federal lands for the leasable minerals is: $6 \%$ closed, $38 \%$ highly restricted, and $56 \%$ open with moderate or slight restrictions. For the locatable minera1s, $14 \%$ is closed, $32 \%$ is highly restricted, and $54 \%$ is open with moderate or slight restrictions.

Impacts to the mineral industry and to the general public from withdrawing some western federal lands from exploration and potential development are difficult to estimate. Our analysis indicates that less federal acreage is withdrawn in the west than is commonly believed by industry (AIPG, 1981). We did, however, find that about $40 \%$ to $45 \%$ of the federal land in the West is now effectively closed to mineral activity (the sum of the acreage in the "formally closed" and "highly restricted" categories, see Appendix). It therefore seems reasonable to believe that some reductions in mineral availability have occurred and will continue to occur because of this situation. The magnitude and importance of these speculated reductions in mineral supply would be extremely difficult to quantify and are beyond the scope of this study.

During the next 10 years, we conclude that the availability of western federal lands will increase substantially. For leasable minerals, we estimate the availability to increase from $56 \%$ in 1981 to $68 \%$ by 1990 . For locatable minerals, we estimate the availability to increase from $54 \%$ in 1981 to $69 \%$ by 1990 . These increases are attributed to:

1. The release of about 27.1 million acres of Forest Service land in the West that was recommended for nonwilderness during the RARE-II program (Roadless Area Review and Evaluation). We considered mineral activities on these lands to be highly restricted in 1981 (see Appendix). 
2. The release of an unknown amount of the 7.0 million acres of Forest Service land in the West that was assigned to the further planning category during the RARE-II program. We estimated that 3.5 million acres of this area would be released by 1990 , but we considered the entire 7.0 million acres to be highly restricted in 1981 (see Appendix).

3. The release of an unknown amount of the 24.3 million acres of WSAs now under wilderness review by the BLM. We estimated that $25 \%$ of the WSA acreage would be included in the National Wilderness Preservation System and another 25\% would be in a further planning category by 1990. We considered the entire 24.3 million acres of WSAs to be highly restricted for mineral activities in 1981 (see Appendix).

4. The release of many millions of acres of federal land (by the Reagan administration) as a result of accelerated review and revocation of antiquated land-withdrawl orders.

As more federal lands in the West are released during the next 10 years, land withdrawals, especially for environmental reasons (e.g., wilderness, parks, and wildlife sanctuaries), should not be a major barrier to increased mineral production. This situation assumes, of course, that WSAs with a high potential for energy resources are not recommended for inclusion in the National Wilderness Preservation System. We believe this assumption is reasonable because the BLM is required by law to include mineral values in its decision process.

Several areas are recommended to the BLM for accelerated WSAsuitability studies (Fig. 1). Each area has a significant potential for energy resource(s) as well as a large acreage and number of WSAs. 


\section{INTRODUCTION}

\section{BLM'S WILDERNESS REVIEW PROGRAM}

The Federal Land Policy and Management Act of 1976 mandated that the BLM begin a study of the approximately 400 million acres of BLMadministered land to identify areas for possible inclusion in the National Wilderness Preservation System. About 175 million acres of this land is in the conterminous United States west of $102^{\circ}$ west longitude-the 11 western states referred to as the "West" in this report. The remaining BLM-acreage is almost entirely in Alaska. (The BLM's wilderness review program was recently halted in Alaska except for areas specifically identified for study under provisions of the Alaska National Interest Lands Conservation Act of 1980.) By October 21, 1991, the BLM must accomplish three tasks: (1) identify areas of 5000 acres or more that are roadless and that may have wilderness characteristics; those so identified will be called WSAs; (2) evaluate the WSAs to determine their suitability for wilderness recommendation; and (3) report these findings and the land-use recommendations for each WSA to the President. The President will then submit recommendations to Congress, and Congress will decide which WSAs will become wilderness.

In the spring of 1981 the BLM completed task 1. About 24.3 million acres of BLM land in 947 separate WSAs had been identified in the 11 western states (personal communication to E. H. Oakes, November 1981, Jim Edward, BLM-Washington). During the next several years, each BLM district will evaluate the resources within its WSAs to determine which WSAs are suitable for inclusion in the National Wilderness Preservation System (task 2). The studies will include analyses of mineral and energy resources, recreational resources, grazing potential, wilderness values, 
and other values. The information used to determine these resource values will be gathered by the BLM staff within each district. Evaluation of each WSA will include a review of district records and available literature, and input from state and federal agencies, industry, private groups, and individuals (see Federal Register, 12/10/81, p. 60562-3, for the format proposed by the BLM to gather mineral information for the wilderness review program). Criteria to be used by the BLM to determine the suitability of WSAs for inclusion in the wilderness system were published in the Federal Register (12/19/80, p. 83780-4). Those WSAs judged by the BLM to be suitable for wilderness recommendation must, by law, have a mineral-resource appraisal conducted by the U.S. Geological Survey and the U.S. Bureau of Mines. For more details on the BLM's wilderness review program, see BLM (1978; 1979a).

\section{PURPOSE OF THIS DOE STUDY}

A part of this nation's existing and fulure supply, of energy resources lies in the 11 western states. Depending on the number and acreage of WSAs that are ultimately designated as wilderness, an undetermined part of the energy resources in these states will be precluded from development (unless, of course, these wilderness areas are subsequently removed from the National Wilderness Preservation System by congressional action).

The primary purpose of this study is to identify areas in the West that have both a large acreage of WSAs and an important energy-resource potential. During the past two years, we submitted to the BLM two previous unpublished reports on this topic. The first report was submitted in September 1979 (revised November 1979) after BLM had identified the initial inventory of roadless areas. The second report was submitted 
in August 1980 after BLM had identified potential WSAs. This report is therefore our final statement on the overall coincidence of WSAs and areas of important energy-resource potential; the report is based on the BLM's final decisions, made largely in 1981 , regarding the location and size of WSAs in the 11 western states.

The BLM's wilderness review program touches on many controversial. topics. Because of the nature of this study (an overview) and because this is our final report, we decided to expand the study to include two topics that we consider relevant to the BLM's program: (1) the existing and potential future-role of western federal lands as a supplier of energy and energy resources, and (2) the current and future status of the availability of western federal lands for mineral activities (see "Scope of Study" and the Appendix for more details).

\section{SCOPE OF STUDY}

The energy resources evaluated for this study include oil, gas, uranium, coal, geothermal, and hydroelectric power--nonfuel mineral resources are not included. The region studied is the onshore area of the 11 western states: Washington, Oregon, California, Nevada, Idaho, Utah, Arizona, New Mexico, Colorado, Wyoming, and Montana. Lands where the federal government owns the mineral estate but not the surface rights were not included in the category of "federal land." Thus, the total amount of western federal land evaluated for this study (including the Appendix) is about 360 million acres. Alaska vas not included because the BLM's wilderness review program was recently halted in Alaska by the Secretary of the Interior; thus, the BLM's wilderness review program will have little impact on the future availability of energy resources from 
Alaska. Other energy resources, such as oil shale, oil-impregnated sandstone, solar energy, wind energy, and biomass, were not included in this overview study.

The BLM wilderness review program--1ike the earlier RARE-II program of the U.S. Forest Service--is part of a national land-use planning effort for federal lands. A fundamental problem of informed land-use planning, and a topic of considerable disagreement between the minerals industry and environmental groups, is the acreage of federal land now available for mineral exploration and potential development. Because of this controversy, we have included in the Appendix an analysis of the current and future availability of western federal lands for mineral activities. We believe that this subject is relevant to the ELM's wilderness review program because land-use decisions for WSAs can be influenced by the beliefs and/or bias of land managers and interest groups regarding the amount of federal land available for mineral activities. We therefore believe that the BLM's wilderness review program, the continued availability of energy resources, and the broader question of the availability of federal lands for mineral activities are intricately related and require an integrated analysis. 


\section{Part 1 .}

\section{ENERGY RESOURCES, RESERVES, AND PRODUCTION IN THE WESTERN UNITED STATES AND \\ THE ROLE OF WESTERN FEDERAL ONSHORE LANDS}

\section{INTRODUCTION}

To estimate the potential impacts of the fil's wilderness review program on our future supply of energy resources, the energy-resource potential of western federal lands must be established. We have illustrated this potential in Tables 3 through 8 for each energy resource evaluated in this study.

Estimates of mineral-resource potential vary through time as new data become available. Most past resource estimates, when compared with current estimates for the same resource, are pessimistic. For example, the U.S. Geological Survey in 1975 estimated that the volume of undiscovered, recoverable gas in the western Rocky Mountains ranged from 6 to 25 trillion cubic feet (Miller et a1. 1975). In 1981, 11sing additional data, the U.S. Geological Survey revised this estimate to a range of 54 to 90 trillion cubic feet of gas (Dolton et a1. 1981). Because estimates of mineral-resource potential can, and usually do, change through time, some people have argued that land-use decisions based on these estimates will ultimately be proved wrong; therefore no lands should ever be withdrawn from mineral activities. Our response is that, indeed, some landuse decisions made today may, with hindsight, be improper decisions from a strictly minerals standpoint. But, the fear of making a wrong or improper decision based on incomplete data must be balanced with the knowledge that the FLM and other land-management agencies are required by law to make land-use decisions within a specified time. Moreover, the 
minerals industry should recognize that there are other legitimate, indeed, legislatively-mandated, uses of federal land. We therefore maintain that the use of current estimates of mineral-resource potential, however inadequate, is the only way of making informed land-use tradeoffs that are in the best interests of society.

\section{METHOD OF STUDY}

For this part of the study, we obtained the most recent national assessments by the government for each energy resource. (Estimates of national resource-potential prepared by industry and other private institutions were not included.) We then allotted a part of the total resource to western federal lands (and to WSAs; see Part 2). Most government resource assessments segregate the country into geologic or physiographic provinces. The potential magnitude of undiscovered resources (such as gas or uranium) within each province is then estimated. If the amount of federal land within the province is known, the resource potential of these lands can be reasonably estimated from the proportion of federal to nonfederal land. If appropriate, this estimate can then be subjectively increased or decreased, depending on the actual coincidence of federal land and resource potential within the province.

Supporting data for the analyses in this section are listed in the footnotes in Tables 3 through 8. For ease of comparison, data in the tables are segregated into three land-area categories: (1) total area of the United States (2.3 billion acres onshore; 3.1 billion acres onshore plus offshore for oil and gas estimates in Tables 3 and 4); (2) total onshore area of the West (760 million acres); and (3) total onshore area 
of western federal lands (359 million acres). Statistical data on the West's federal lands, such as ownership by agency, are contained in Table A.1 in the Appendix.

In the tables that follow and throughout this report, the term "reserves" is defined generally as a quantity of raw materials (minerals) KNOWN TO EXIST that can be extracted economically at the present time. "Resources," on the other hand, are BELIEVED T'O EXIST (with varying degrees of reliability) on the basis of analysis of available geologic data. [Strictly speaking, reserves are a subset of resources. For more information on resource terminology, see USGS/USBM (1980).]

\section{OIL AND GAS}

Western federa1 onshore lands contributed about $5 \%$ of the oil and $5 \%$ of the gas produced annually in the United States in the late $1970 \mathrm{~s}$ (Tables 3 and 4). The volume of oil and gas reserves on western federal onshore lands is not known with certainty. Porter (1980, p. 7) estimates that on $1 y \quad 8.8 \%$ of the entire nation's oil reserve and $13 \%$ of the nation's gas reserve are federally owned (includes onshore and offshore demonstrated and inferred reserves, and lands for which the government owns only the mineral estate). Thus, from the standpoint of current and nearfuture petroleum production, western federal onshore lands are not now, nor will they be, a large contributor to the nation's oil and gas requirements. This conclusion is made on the basis of acreage--western federal onshore lands comprise $12 \%$ of the total onshore and offshore area of the United States (Do1ton et a1. 1981), yet it is doubtful if even $5 \%$ of U.S. oil reserves and $10 \%$ of U.S. gas reserves can be attributed to these 1ands. 
Table 3. Comparison of oil production, reserves, and resources in the United States, the 11 western states, and western federal onshore lands

Annua1

production

Reserves

Resources

[billion barrels (percent of total)]

Western federal onshore lands a

The 11 western states

Total U.S.f
$0.14(5 \%)^{b}$

$0.57(19 \%)^{d}$

$2.95^{\mathrm{d}}$
Not

available

$5.3(20 \%)^{d}$

$27.6(33 \%)^{\mathrm{e}}$

$27.1 \mathrm{~g}$
$16(19 \%)^{c}$

$82.6^{\mathrm{h}}$

ancludes public and acquired lands in the 11 western states, a total of 359 million acres (BLM 1981).

bata for fiscal year 1979; includes public and acquired lands (BLM 1981, Tables 74 and 75 , p. 95-96).

$\mathrm{c}_{\text {This }}$ volume is based on a subjective evaluation, using mean estimates contained in Dolton et a1. (1981) for undiscovered, recoverable resources. We consider this percentage to be a reasonable upper limit for oil resources on western federal onshore lands. The estimate was derived as follows: undiscovered, recoverable oil resources in the western United States are estimated at 27.6 billion barrels (see footnote e). Federal lands in the West total about 359 million acres (BLM 1981 ) or $47 \%$ of the total area of 760 million acres. On a strictly linear barrel-per-acre basis, western federal lands might therefore account for $47 \%$ of the West's oil resources, or about 13.0 billion barrels. The oil potential of the West, however, varies considerably from one place to another. To account for the inconsistencies in the distribution of federal lands and oil potential, we calculated the federal acreage within each subprovince evaluated by Dolton et al. (1981). In the 11 western states, this amounted to 35 subprovinces and parts of 4 other subprovinces. The oil potential of the federal lands within each subprovince was then calculated on the basis of the proportion of federal and nonfederal lands, totaled for a volume of 16.2 billion barrels, and rounded to 16 billion barrels. The map used to calculate the federal acreage within each subprovince was at a scale of $1: 2,500,000$ (USGS 1965). The total federal area in the West, as planimetered directly from this map and adjusted where possible by using data in BLM (1981, p. 9) (and not including Indian reservations), was 
Table 3 (continued)

419 million acres, or about $17 \%$ more than the actual current federal acreage in the West of 359 million. Thus, our assignment of $19 \%$ of the oil resource potential of the country to western federal onshore lands should be considered an upper limit.

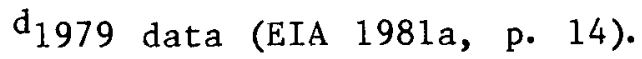

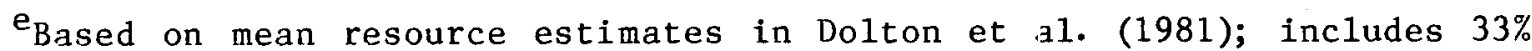
of oil potential of Williston Basin ( 0.5 billion barrels), $75 \%$ of oil potential of Denver Basin ( 0.6 billion barre1s), $25 \%$ of oil potential of Permian Basin ( 0.7 billion barrels), and $10 \%$ of oil potential of Anadarko Basin (0.2 billion barrels).

$\mathrm{f}_{\text {Includes }}$ offshore areas.

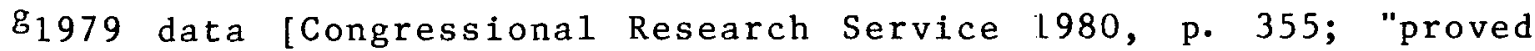
reserves" as reported by the American Petroleum Institute. On the other hand, EIA (1981a, p. 14) reports national oil reserves as of December 1979 at 29.8 billion barrels and the West's reserves at 6.3 billion barrels].

h Mean estimate by U.S. Geological Survey for onshore and offshore areas (a total area of 3.1 billion acres; Dolton et al. 1981). Mean estimate for onshore oil resources is 54.6 billion barrels; and for offshore oil resources, 28.0 billion barrels. 
Table 4. Comparison of natural gas production, reserves, and resources in the United States, the 11 western states, and western federal onshore lands ${ }^{a}$

Annua1

production Reserves Resources

[trillions of cubic feet (percent of total)]

\begin{tabular}{lccc}
\hline $\begin{array}{l}\text { Western federal } \\
\text { onshore lands }\end{array}$ & $0.9(5 \%)^{\mathrm{c}}$ & $\begin{array}{c}\text { Not } \\
\text { available }\end{array}$ & 100 \\
$\begin{array}{l}\text { The } 11 \text { western } \\
\text { states }\end{array}$ & $2.1(11 \%)^{\mathrm{e}}$ & $26.9(14 \%)^{\mathrm{f}}$ & $160.8(27 \%)^{\mathrm{d}}$ \\
Total U.S.h & $19.3^{\mathrm{e}}$ & $194.9^{\mathrm{f}}$ & $593.9^{\mathrm{i}}$ \\
\hline
\end{tabular}

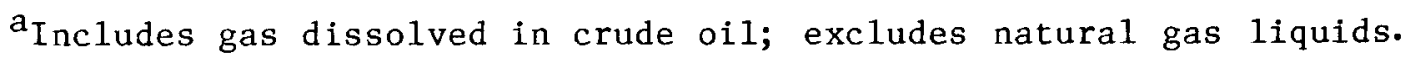

${ }^{b}$ Includes public and acquired lands in the 11 western states, a total of 359 million acres (BLI1 1981).

${ }^{C_{D}}$ Data for fiscal year 1979; includes public and acquired lands (BLM 1981, Tables 74 and 75 , p. 95-96).

$\mathrm{d}_{\text {This }}$ volume is based on a subjective evaluation, using mean estimates contained in Dolton et al. (1981) for undiscovered, recoverable resources. We consider this percentage to be a reasonable upper limit for gas resources on western federal lands. The estimate was derived as follows: undiscovered, recoverable gas resources in the western United States are estimated at 160.8 trillion cubic feet (see footnote $g$ ). Federal lands in the West total about 359 million acres (BLM 1981), or $47 \%$ of the total area of 760 million acres. On a strictly linear cubicfoot-per-acre basis, western federal lands might therefore account for $47 \%$ of the West's gas resources, or about 75.6 trillion cubic feet. The oil potential of the West, however, varies considerably from one place to another. To account for the inconsistencies in the distribution of federal lands and gas potential, we calculated the federal acreage within each subprovince evaluated by Dolton et al. (1981). In the 11 western states, this amounted to 35 subprovinces and parts of 4 other subprovinces. The gas potential of the federal lands within each subprovince was then calculated on the basis of the proportion of federal and non-federal lands, totaled for a volume of 102.2 trillion cubic feet, and rounded to 100 trillion cubic feet. The map used to calculate the federal acreage within each subprovince was at a scale of $1: 2,500,000$ (USGS 1965). The total federal acreage in the West, as planimetered directly from this map and adjusted, where possible, with 
Table 4 (continued)

data in BLM (1981, p. 9) (and not including Indian reservations), was 419 million acres, or about $17 \%$ more than the actual current federa1 area in the West of 359 million. Thus, our assignment of $17 \%$ of the gas resource potential of the country to western federal onshore lands should be considered an upper limit.

e 1979 data (EIA 1981a, p. 21).

f 1979 data [Congressional Research Service 1.980, p. 355; "proved reserves" as reported by the American Petroleum Institute and the American Gas Institute. On the other hand, EIA (1981a, p. 21) reports national gas reserves as of December 1979 at 200.9 trillion cubic feet and the West's reserves at 30.1 trillion cubic feet].

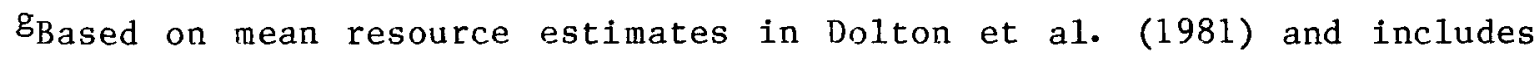
$33 \%$ of gas potential of Williston Basin ( 1.1 trillion cubic feet), $75 \%$ of gas potential of Denver Basin (1.7 trillion cubic feet), $25 \%$ of gas potential of Permian Basin ( 8.3 trillion cubie feet), and $10 \%$ of gas potential of Anadarko Basin ( 3.5 trillion cubic feet).

${ }^{h}$ Includes offshore areas.

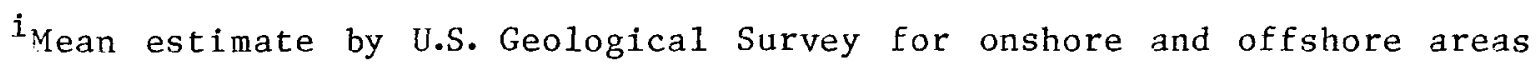
(a total area of 3.1 billion acres; Dolton et al. 1981). Mean estimate for onshore gas resources is 426.9 trillion cubic feet; and for offshore gas resources, 167.0 trillion cubic feet. 
Over the long term, however, western federal lands have a significant potential to supply the United States with proportionally larger amounts of oil and gas. We estimate that federal onshore lands in the West contain up to $19 \%$ of our undiscovered, recoverable oil resources and up to $17 \%$ of our undiscovered, recoverable gas resources (Tables 3 and 4; see footnotes $c$ and $d$, respectively, for an explanation of how these estimates were derived). Because these lands constitute only about $12 \%$ of the total area assessed by Dolton et a1. (1981), but may contain $19 \%$ of our undiscovered oil resources and $17 \%$ of our undiscovered gas resources, they represent an important potential future source of petroleum.

The petroleum potential of western federal lands is distributed very unevenly. For example, the Idaho-Wyoming-Utah thrust belt, which contains a large amount of federal land, accounts for $8 \%$ of the entire nation's undiscovered oil resources and $10 \%$ of the nation's gas resources (based on mean estimates in Dolton et a1. 1981). This represents $24 \%$ of the total undiscovered oil resources in the West and $36 \%$ of the undiscovered gas resources. If combined with other parts of the thrust belt in Montana, Utah, and Nevada (subregions 82 and 98 in Dolton et al. 1981, p. 12), the amount increases to $38 \%$ of the West's total oil resources of 27.6 billion barrels and about $49 \%$ of the West's total gas resources of 160.8 trillion cubic feet (based on mean estimates in Dolton et al. 1981). Thus, much of the remaining federal domain in the West, such as large parts of Nevada, California, Idaho, Arizona, and elsewhere, has a low potential for oil and gas.

In summary, the oil and gas potential of some federal lands in the West is clearly significant. However, current models of oil and gas accumulation and recent estimates by the U.S. Geological Survey indicate 
that much of the West's onshore federal domain is relatively unimportant as a potential future source of petroleum.

\section{URANIUM}

Annual uranium production from western federal lands in the late 1970 s is estimated to be about $75 \%$ of total U.S. output (Table 5). The Colorado Plateau and Wyoming basins are, by far, the most important areas for uranium production and for reserves and resources (DOE 1980b; 1981a). These two regions combined account for $85 \%$ of the total uranium reserves and $52 \%$ of the total resources of the nation (DOE 1980b, p. 14; resources include the sum of the total uranium estimated for the probable, possible, and speculative resource categories at the $\$ 100 / 1 \mathrm{~b}$ forward-cost category, as defined by DOE).

Western federal lands are estimated to contain $48 \%$ of the nation's uranium reserves and $59 \%$ of our resources (Table 5). Expressed another way, western federal lands account for on 1 y $16 \%$ of the total land area of the country, yet contain almost $50 \%$ of our uranium reserves and almost $60 \%$ of our resources. Almost equally important are western nonfederal lands, which, together with western federal lands, account for $95 \%$ of a11 uranium reserves in the United States and $84 \%$ of a11 resources (Table 5).

By any standard of measure, federal lands in the west are quite important in terms of their past, present, and potential future contributions to the uranium requirements of the United States. The distribution of uranium resources on western federal lands, however, is extremely uneven, as is clearly demonstrated by the overwhelming importance of only a few areas. 
Table 5. Comparison of uranium oxide production, reserves, and resources in the United States, the 11 western states, and western federal lands

Annual

Production Reserves Resources

[tons uranium oxide, (percent of total)]

$\begin{array}{lccc}\begin{array}{l}\text { Western federal } \\ \text { lands }\end{array} & 14,048(?)(75 \%)^{\mathrm{b}} & 539,000(48 \%)^{\mathrm{c}} & 2,230,000(59 \%)^{\mathrm{c}} \\ \begin{array}{l}\text { The } 11 \text { western } \\ \text { states }\end{array} & 16,857(?)(90 \%)^{\mathrm{d}} & 1,061,000(95 \%)^{\mathrm{e}} & 3,163,000(84 \%)^{\mathrm{e}} \\ \text { Total U.S. } & 18,730^{\mathrm{f}} & 1,122,000 \mathrm{~g} & 3,781,000^{\mathrm{h}}\end{array}$

${ }^{a}$ Includes public and acquired lands in the 11 western states--a total of 359 million acres (BLM 1981).

${ }^{b}$ According to Zimmermann (1979, p. 1), "As of January 1974, over 75 percent of the uranium being produced in this country was mined from deposits discovered on lands owned by the Federal Government." This figure is probably representative of annual uranium production from federal lands in the late 1970s. Because the West contains essentially all the federal lands where uranium has been and is being produced, we have assigned $75 \%$ of the nation's total 1979 uranium production to western federal land $(75 \%$ of 18,730 is 14,048$)$. This figure includes production from leases issued on acquired lands and production from Indian lands.

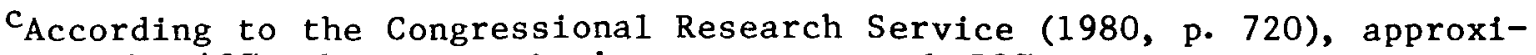
mately $48 \%$ of our nation's reserves and $59 \%$ of our resources are contained on federal lands. These estimates were made for reserves and resources at a $\$ 50 / 1 \mathrm{~b}$ forward-cost category as of Jan. 1, 1979, and do not include Indian lands. We have assumed that these percentages are reasonably close to uranium reserves and resources at the $\$ 100 / 1 b$ forward-cost category and therefore have used these percentages to calculate reserves and resources on western federal lands at the $\$ 100 / 1 b$ forward-cost category. In addition, we have attributed the reserve and resource estimates listed under the various federal land categories in the report by Congressional Research Service (1980, p. 720) to western federal lands--despite the fact that lands east of Colorado contain $5 \%$ of our reserves and $16 \%$ of our estimated uranium resources (DOE 1980b). Uranium reserves and resources in Alaska are estimated at zero and less than $1 \%$, respectively, of the national totals (DOE 1980b). Thus, we consider the uranium reserve and resource estimates in this table to be reasonable upper limits for western federal lands. 
Table 5 (continued)

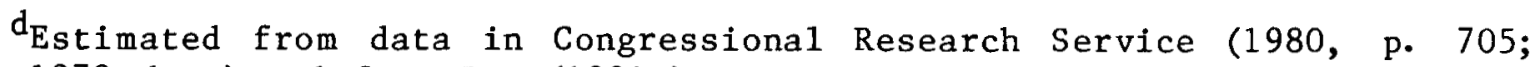
1979 data) and from DOE (1981a).

e Data from DOE (1980b, p. 14). Totals in reserve and resource columns include all uranium reserves/resources assigned to the Great Plains province, only part of which is included in the 1.1 western states. Data are for reserves and resources in the $\$ 100 / 1 \mathrm{~b}$ forward-cost category.

f Congressional Research Service (1980, p. 705; 1979 data).

gReserve estimate at a forward-cost category of $\$ 100 / 1 b$ uranium oxide (DOE $1980 \mathrm{~b}$, p. 1), which includes all uranium at the $\$ 50 / 1 \mathrm{~b}$ and $\$ 30 / 1 \mathrm{~b}$ forward-cost categories.

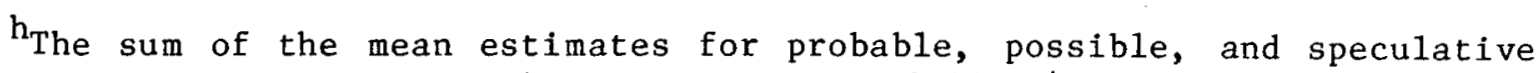
resources at a forward-cost category of $\$ 100 / 1 b$ uranium oxide (DOE $1980 \mathrm{~b}, \mathrm{p} .1$ ). 
COAL

Production of federal coal in the West amounted to about $9 \%$ of total U.S. production during 1978 and 1979 (Table 6). This percentage is expected to increase during the next few years because $32 \%$ of the nation's total coal reserve is owned by the federal government in the West (Table 6). Furthermore, 59\% (by weight) of the nation's surfaceminable coal reserve is contained in the West, largely in the Powder River Basin, where the government owns almost $80 \%$ of the coal (BLM $1979 \mathrm{~b})$. In many areas of the West containing federal coal, however, the government does not own the surface rights (see footnote $c$, Table 6, for a discussion and an estimate of the amount of federal coal underlying only those lands for which the government also owns the surface rights).

The government owns $70 \%$ of the West's coal reserve (141 billion tons) out of a total western reserve of 205 billion tons (Table 6). But, almost $80 \%$ of the government's western coal, or about 113 billion tons, is contained in the Powder River Basin in Montana and Wyoming. Excluding the Powder River Basin, the West contains about 53.8 billion tons of coal; $52 \%$ is owned by the federal government (about 27.5 billion tons of federal coal). For comparison with the Powder River Basin, the amount of federal coal in the other western coal regions is as follows (data from BLM 1979b, p. 2-47): (1) 9 billion tons in the Fort Union Region (northern Montana and the Dakotas); (2) 8.7 billion tons in the Green River Region (western half of Wyoming and small parts of northern Colorado and north-central Utah); (3) 5.9 billion tons in the UtahEastern Colorado Region; (4) 0.7 billion tons in the Denver-Raton Mesa Region (just east of the Rockies, extending from northern Colorado into New Mexico); and (5) 3.2 billion tons in the San Juan River Region (New Mexico and the Four Corners area). 
Table 6. Comparison of coal production and demonstrated reserves ${ }^{a}$ in the United States, the 11 vestern states, and the western federal lands

Annual

production Reserves

[billions of short tons (percent of total)]

Western federa1 $\quad 58.2(9 \%)^{b}$
lands

The 11 western states

Total U.S. $670.2^{\mathrm{f}}$
$141(32 \%)^{\mathrm{C}}$ [Amount of federal coal underlying surface areas owned by the federal government is not known.]

$205(47 \%)^{e}$

$134.5(20 \%)^{\mathrm{d}}$

(205 $(47 \%)$

$438 \mathrm{~g}$

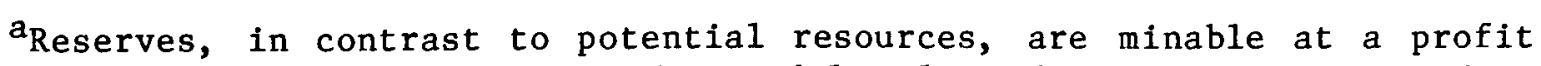
under technological, economic, and legal conditions existing today. Reserves are generally grouped into two categories -- demonstrated and inferred. The demonstrated reserves are known to exist with a greater degree of certainty than are the inferred reserves. See USGS/USBM (1980) for more information on resource terminology.

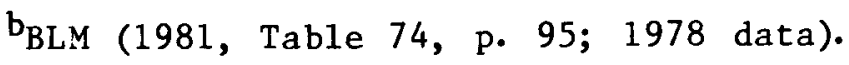

$\mathrm{c}_{\text {BLM }}(1979 \mathrm{~b}$, Table 2-29, p. 2-47). The tonnage in this category includes all coal owned by the federal government in the West, regardless of surface ownership. We asked the U.S. Geologj.cal Survey in Reston, Virginia, for an estimate of the tonnage of federal coal underlying only those lands that are owned (surface rights) by the federal government, but we were informed that this information is not available. We speculate that, of the 141 billion tons of western federal coal, far less than $50 \%$ underlies western federal land. This conclusion is based on the distribution of surface ownership in "Known Recoverable Coal Resource Areas" identified by the U.S. Geological Survey, especially in the coal-rich Powder River Basin where the Government owns only $25 \%$ of the land overlying federal coal reserves (BLM 1979b, p. 2-9).

dCongressional Research Service (1980, p. 10; preliminary 1978 data). 
Table 6 (continued)

e BLM (1979b, Table 2-2, p. 2-4); does not include North and South Dakota. The most recent estimate of coal reserves in the West, excluding North and South Dakota, is 219.7 bil1ion tons (EIA $1981 \mathrm{~b}$, p. 8; see footnote $g$ ).

${ }^{f}$ Congressional Research Service (1980, p. 8; 1978 data); preliminary data for coal production in 1979 is 776 million tons (from same source).

g BLM (1979b, p. 2-1). The most recent estimate of coal reserves for the nation is 475 billion tons (EIA $1981 \mathrm{~b}, \mathrm{p} .7$ ), but the proportion of federal coal was not distinguished in this publication. According to Glass (1981), reserve estimates for western coal, especially in Colorado, Wyoming, and Montana, are inaccurate because they are based largely on old geologic reports. BLM (1979b, p. 2-1) states that the coal reserve estimates for the West are probably much too low. 
As of March 1978, about 17.4 million acres in the West had been identified by the U.S. Geological Survey as "known recoverable coal resource areas" (KRCRAs) (BLM 1979b, p. 2-5). The KRCRAs include federal and nonfederal coal and are the areas considered to have a high to moderate potential for coal development. Of this 17.4 million acres of western KRCRAs, on1y 4.7 million acres (27\%) is federal land in which the government also owns the mineral rights. The remaining KRCRA acreage is, for the most part, in one of two categories: (1) nonfederal coal with nonfederal surface ownership ( 5.8 million acres or $34 \%$ of total KRCRA acreage), and (2) federal coal with nonfederal surface ownership (6.7 million acres or $39 \%$ of total KRCRA acreage). The BLM (1979b, p. 2-5) estimates that the federal government owns $72 \%$ of the coal reserves in KRCRAs, largely because of the federal government's share of coal in the Powder River Basin.

In summary, the federal government owns about $70 \%$ of the coal in the West, but most of the government's coal probably underlies nonfederal lands. Still, coal reserves underlying some federal lands in the West are abundant.

\section{GEOTHERMAL}

Geothermal resources are generally grouped into categories based on the characteristics of the heat transfer system and the geology. Muffler et al. (1978) recognize five types of geothermal resources: (1) conduction-dominated systems (such as hot-dry-rock or heat stored in areas of normal to above-normal geothermal gradients); (2) igneous-intrusive systems; (3) high-temperature $\left(>150^{\circ} \mathrm{C}\right.$ ) and moderate-temperature (90 to $\left.150^{\circ} \mathrm{C}\right)$ hydrothermal systems; (4) low-temperature $\left(<90^{\circ} \mathrm{C}\right)$ hydrothermal 
Table 7. Comparison of geothermal energy production, identified resources, and undiscovered resources in the United States, the 11 western states, and western federal lands

\begin{tabular}{|c|c|c|c|}
\hline & $\begin{array}{c}\text { Annual } \\
\text { production } \\
\text { [megawatts, } \\
\text { (percent of tota } 1)]\end{array}$ & $\begin{array}{c}\text { Identified }^{a} \\
\text { resources } \\
{[1018 \text { Joules }} \\
\text { (percent of total)] }\end{array}$ & $\begin{array}{c}\text { Undiscovered }^{a} \\
\text { resources } \\
{[1018 \text { Joules, }} \\
\text { (percent of total)] }\end{array}$ \\
\hline $\begin{array}{l}\text { Western fed- } \\
\text { eral lands }\end{array}$ & $? ?$ & $1290+(45 \%)^{b}$ & $\begin{array}{c}\text { Data not } \\
\text { available }\end{array}$ \\
\hline $\begin{array}{c}\text { The } 11 \text { west- } \\
\text { ern states }\end{array}$ & $<1000(<100 \%)^{c}$ & $2860 \quad(97 \%)^{d}$ & $6955(87 \%)^{d}$ \\
\hline Total U.S. & $<1000^{c}$ & $2940^{e}$ & $8000^{d}$ \\
\hline
\end{tabular}

according to Muffler et al. (1978, p. 4), "identified" resources refer to specific concentrations of geothermal energy known to exist on the basis of drilling or geochemical, geophysical, and geologic evidence. "Undiscovered" resources are concentrations of geothermal energy surmised to exist on the basis of broad geologic knowledge and theory. The estimated energy in the identified and unidentified categories is to depths not exceeding 1.9 miles (Muffler et al. 1978, p. 157). $\left[1 \mathrm{Joule}(\mathrm{J})=0.239\right.$ calories or $\left.9.5 \times 10^{-4} \mathrm{Btu}\right]$. $\left[10^{18} \mathrm{~J} \simeq 10^{15} \mathrm{Btu} \simeq 1\right.$ quad $]$.

b Includes hydrothermal systems $>90^{\circ} \mathrm{C}$ (and vapor-dominated systems). This is a minimum estimate based on the fact that almost half the nation's identified geothermal resources are within national parks (on federal lands; see footnote e below). Considering the high coincidence between areas containing significant geothermal resources and large acreages of federa1 land (e.g. the Basin and Range province), the proportion of the nation's identified geothermal resources underlying western federal land probably exceeds 65 percent.

$\mathrm{c}_{\mathrm{A} 1 \mathrm{most}} 95 \%$ of this capacity is attributed to The Geysers north of San Francisco, California, at which the capacity is expected to double by 1985 (Bufe 1982; DOE 1981b). Other areas of electrical production from geothermal resources include southern California, southwestern Utah, Nevada, and Hawai. This estimate does not include heat energy extracted and used directly from low-temperature $\left(<90^{\circ} \mathrm{C}\right)$ thermal waters.

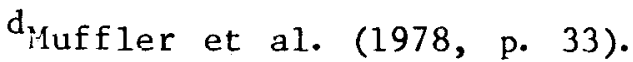

Includes $1290 \times 10^{18}$ Joules in national parks, mainly Yellowstone (Muffler et al. 1978, p. 157). 
systems; and (5) geopressured systems. Many of the systems are interrelated, and boundaries are arbitrary. We consider the most important of these systems, in terms of potentially extractable energy in the near term (the next 20 years), to be the hydrothermal systems of $10 \mathrm{w}$, moderate, and high temperature [types (3) and (4) above]. Because lowtemperature hydrothermal resources are generally believed to occur widely, we conclude that land withdrawals will have little effect on their overall availability should these resources eventually prove economical to use. Therefore, our analysis considers only the moderate- and high-temperature part of the hydrothermal resources [type (3) above].

The West is estimated to contain about $9 \% \%$ of the nation's geothermal resources in systems greater than $90^{\circ} \mathrm{C}$ and at depths of less than 1.9 miles (Table 7). We attribute about one-hal: $\overline{\text { of }}$ the $97 \%$ to western federal lands (see Table 7, footnote b). Many teihnological problems and geological uncertainties must be overcome, however, before hydrothermal systems in the West can be developed economically. If one considers the overall energy contributions potentially made by geothermal resources, and excludes The Geysers in California, low- and moderate-temperature $\left(<150^{\circ} \mathrm{C}\right)$ hydrothermal resources may ultimately provide more energy in the form of direct heat extraction than the few high-temperature geothermal developments that may be producing electricity by the year 2000 .

\section{HYDROELECTRIC POWER}

Hydroelectric power contributed about $5 \%$ annually to our national energy supply in the late 1970s (DOE 1980a) but supplied a much larger part of the electrical requirements in some parts of the country (e.g., the Pacific Northwest). The installed hydroelectric capacity and hydroelectric potential of the country are (1) 63,702 megawatts at existing 
Table 8. Comparison of hydroelectric power production and potential (at identified sites) in the United States, the 11 western states, and western federal lands $^{a}$

\begin{tabular}{l}
\hline $\begin{array}{c}\text { Annual } \\
\text { production } \\
\text { [megawatts (percent of total)] }\end{array}$ \\
\hline $\begin{array}{l}\text { Western federal } \\
\text { lands }\end{array}$ \\
$\begin{array}{l}\text { The } 11 \text { western } \\
\text { states }\end{array}$ \\
$\begin{array}{l}\text { Total U.S. } \\
\text { identif ied sites }\end{array}$
\end{tabular}

${ }^{a}$ All data in this table are from U.S. Army Corps of Engineers (1979).

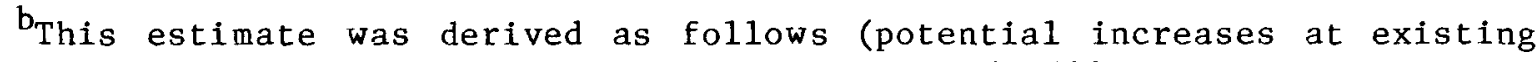
facilities have not been included): of the 140,648 megawatts of potential hydroelectric energy identified in the West, 72\% (101,267 megawatts) is attributed to Washington, Oregon, and Idaho (U.S. Army Corps of Engineers 1979). A large part of this potential is within the mountainous parts of these states on land administered chiefly by the U.S. Forest Service. We have arbitrarily assigned one-half the hydroelectric potential of this region to federal lands (50,000 megawatts). The only other western states with a significant potential for hydroelectric energy are Montana (15,313 megawatts) and California (13,053 megawatts). Once again, the hydroelectric potential will be chiefly in the mountainous areas of each state, where much of the acreage is administered by the U.S. Forest Service. We have again assigned one-half the potential in each state to federal lands, for a combined total with the Northwest of 14,183 megawatts. The six remaining western states have a combined hydroelectric potential of 11,577 megawatts. Because of the large amount of federal lands in these states (administered largely by the BLM and the U.S. Forest Service), we assigned all their hydroelectric potential to federal lands. On the basis of these assumptions, the total identified hydroelectric potential assigned to western federal lands amounts to 75,760 megawatts, which has been rounded to 75,000 megawatts. This represents $53 \%$ of the total potential of the West and $21 \%$ of the nation's hydroelectric power potential. 
sites; (2) 94,636 megawatts of additional potential at existing sites; and (3) 353,948 megawatts of potential at undeveloped, identified sites (U.S. Army Corps of Engineers 1979).

The West contains $40 \%$ of the nation's hydroelectric potential (Table 8). The proportion contained on western federal lands, although not known with certainty, is estimated to be about $21 \%$ of the total (Table 8). Most of this potential, however, is probably on lands under the jurisdiction of the U.S. Forest service, rather than the BLM (see footnote b, Table 8).

\section{SUMMARY AND CONCLUSIONS}

Western federa1 lands constitute about $16 \%$ of the total onshore area of the United States, yet account for (1) a large part of our uranium production, reserves, and resources; (2) a large part of our coal reserves; (3) a large part of our identified geothermal resources; and (4) a moderately large share of our oil, gas, and hydroelectric power resources.

As indicated in Figure 2(a), about 8 quads of energy can be attributed each year to energy resources produced from western federal lands in the late 1970 s [based on the potential amount of energy (in quadri1lion Btus, or quads) derived from all energy resources produced annually from western federal lands (DOE 1980a, p. 2-4)]. This output represented about $10 \%$ of our total average energy supply of 79.8 quads for the years 1977 through 1979 (DOE 1980a). A more meaningful comparison emerges if the production of energy resources from western federal lands is compared only with domestic production of energy resources. Thus, if the energy contributions from energy-resource imports are excluded [mainly oil; see Figure 2(a)], domestic energy-resources supplied an annual average of 
ORNL-OWG 82.7793

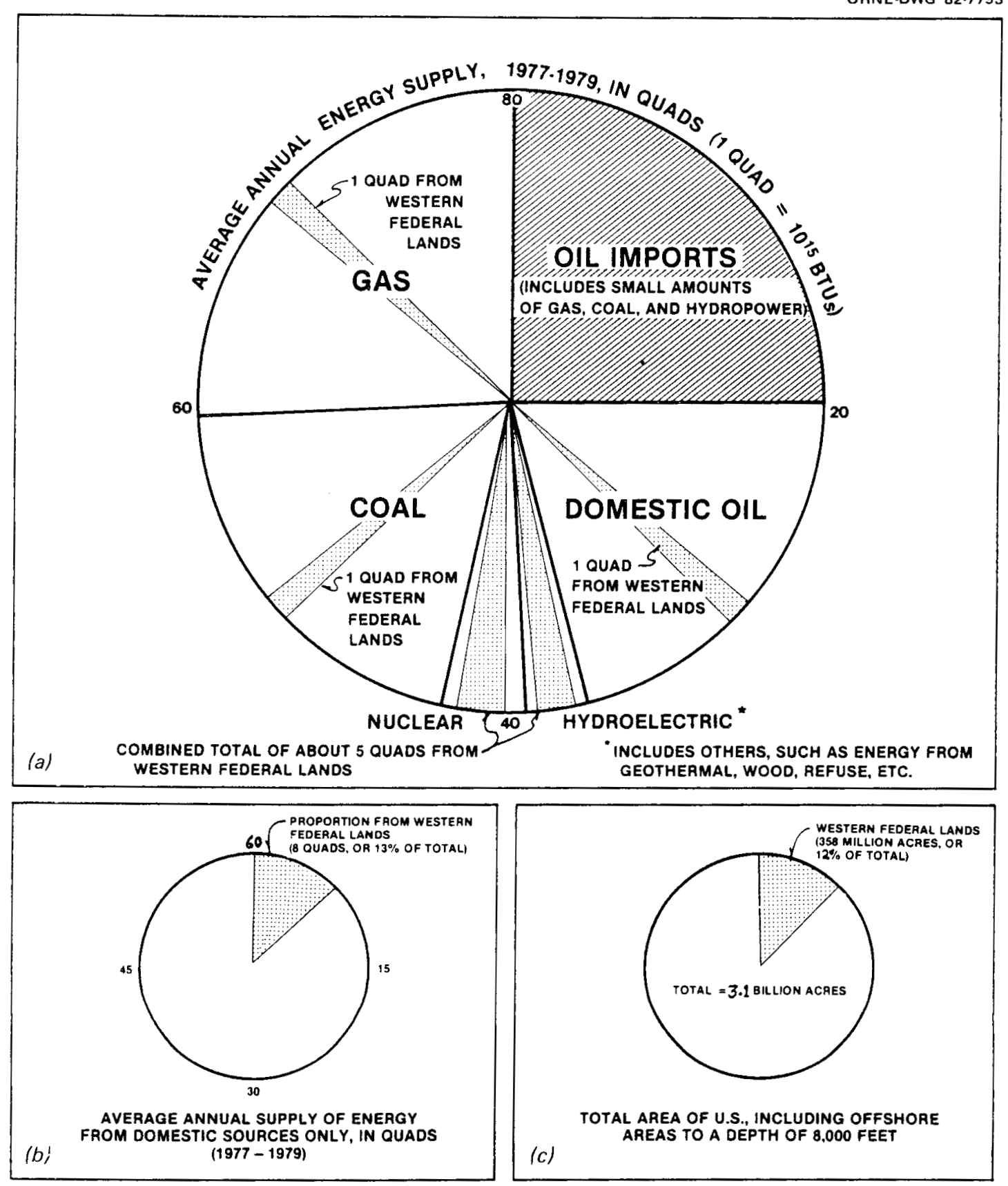

Fig. 2. U.S. supply of energy and energy resources, and the role of western Federal lands. Data averaged for 1977, 1978, and 1979 from DOE (1980a). Average supply of energy for this period was 79.8 quads (consumption was 77.5 quads with the difference being exported). Western Federal lands accounted for about $10 \%$ of total supp 1 y or 8 quads of energy (see "a"). This represented about $13 \%$ of domestic energy supply (see "b") produced from about $12 \%$ of the resource area of the country (see "c"). 
61.4 quads of energy during 1977, 1978, and 1979 [Figure 2(b)]. Of this amount, $13 \%$ ( 8 quads) is attributed to western federal lands, which constitute $12 \%$ of the total area of the United States to an offshore depth of about 8000 feet [Figure 2(c)]. Therefore, compared with domestic production of energy resources (and converted to quads of energy), western federal lands now produce energy resources in amounts roughly proportional to their size.

In the future, a greater share of our energy resources will probably come from western federal lands. There is little doubt that coal production from federal lands in the coal-rich Powder River Basin of Montana and Wyoming will continue to increase, perhaps significantly. $0 i 1$ and gas production from parts of the thrust belt--particularly western Wyoming and northern Utah--should also increase. If energy contributions from nuclear power increase, much of the fuel may come from western federal lands. Thus, in the near future, western federal lands will produce more energy resources than their size alone might suggest. Abundant geologic data, however, indicate that many western federal lands do not have a significant energy-resource potential. The problem, of course, is to identify those areas (and WSAs) that do have a significant potential for energy resources and then transfer this information to the land manager. 


\section{Part 2.}

\section{DESIGNATION OF BLM WILDERNESS AND POTENTIAL IMPACTS \\ ON THE FUTÚRE AVAILABILITY OF ENERGY RESOURCES}

\section{INTRODUCTION}

As indicated in Part 1, a clear potential exists for increased production of energy resources from western federal lands. This part of the report identifies regions in which the most serious conflicts are expected to develop between WSAs and areas with important energy-resource potential. Once identified, the WSAs in these regions are then recommended to the BLM for accelerated studies of their wilderness suitability in order to hasten land-use recommendations and decisions. We have also attempted to characterize, and to quantify where possible, the potential effects on the availability of each energy resource resulting from the withdrawal of WSAs from mineral entry (technically, WSAs are not withdrawn from mineral entry, except for the purposes of this analysis; see below).

The brief analyses that follow are separated by resource type: oil and gas, uranium, coal, geothermal, and hydroelectric power. The energyresource potential map for each resource (except hydroelectric power; Figs. 4-7) illustrates only those areas that are considered to have at least a moderate to high potential for a particular resource, as we have determined from the 1iterature. Areas of minor resource-potential are not considered in the analyses because, on the basjs of current geological and mineral appraisals, resource development is less likely to occur in these areas. Moreover, we wish to emphasize only the areas of most significant conflict between WSAs and potential energy-resources, not every area of possible conflict. 
Each individual resource analysis contains, in the last paragraph, a quantitative estimate of the volume (or tonnage) of the resource that may be contained within the total acreage of WSAs. Derivation of the estimates is explained in each analysis. We consider these estimates to be reasonable upper limits, and three premises should be understood:

1. Estimates apply to the entire 24.3 million acres of WSAs now identified by the BLM in the 11 . western states, a1though many, if not most, of these WSAs will probab1y not be designated as wilderness.

2. Estimates were derived from data in recent government reports, but assumptions and judgments used to assign resources to WSAs were ours. For simplicity, we used the mean amount of resources estimated in these government reports, rather than the range of resource estimates that correspond to various probability-of-occurrence levels, usually $5 \%$ and $95 \%$. The quantity of each resource assigned to WSAs is based on a calculated and/or visual estimate of the WSA-acreage in each of the resource areas defined in these government reports. Where visual estimates were required, we always chose the most reasonable upper limit of WSA-acreage (as a percent of the total acreage of the resource area). We emphasize, however, that land-use decisions will (and should) be made by the BLM on the basis of tract-specific analyses. The cumulative estimates of energy resources assigned to WSAs in this report should therefore be viewed only as a statement of relative energyresource importance.

3. Energy resources assigned to the total WSA-acreage are based on current resource estimates. This is despite the fact that resource estimation is a dynamic process in which estimates are continually reevaluated as additional information becomes available. In general, however, regardless of how the overall resource potential of a region may vary through time, the percentage of total resources that can reasonably be attributed to WSAs within this region will remain about the same. For example, as the oil and gas potential of existing wilderness areas in parts of the western thrust belt has increased during the last six years, so has the oil and gas potential of all other lands in the thrust belt.

\section{DISTRIBUTION OF WSAS IN THE WESTERN UNITED STATES}

Figure 3 shows the distribution of WSAs in the West as of spring

1981. This information was obtained from published reports by the BLM; these reports are available from each BLM state office. 


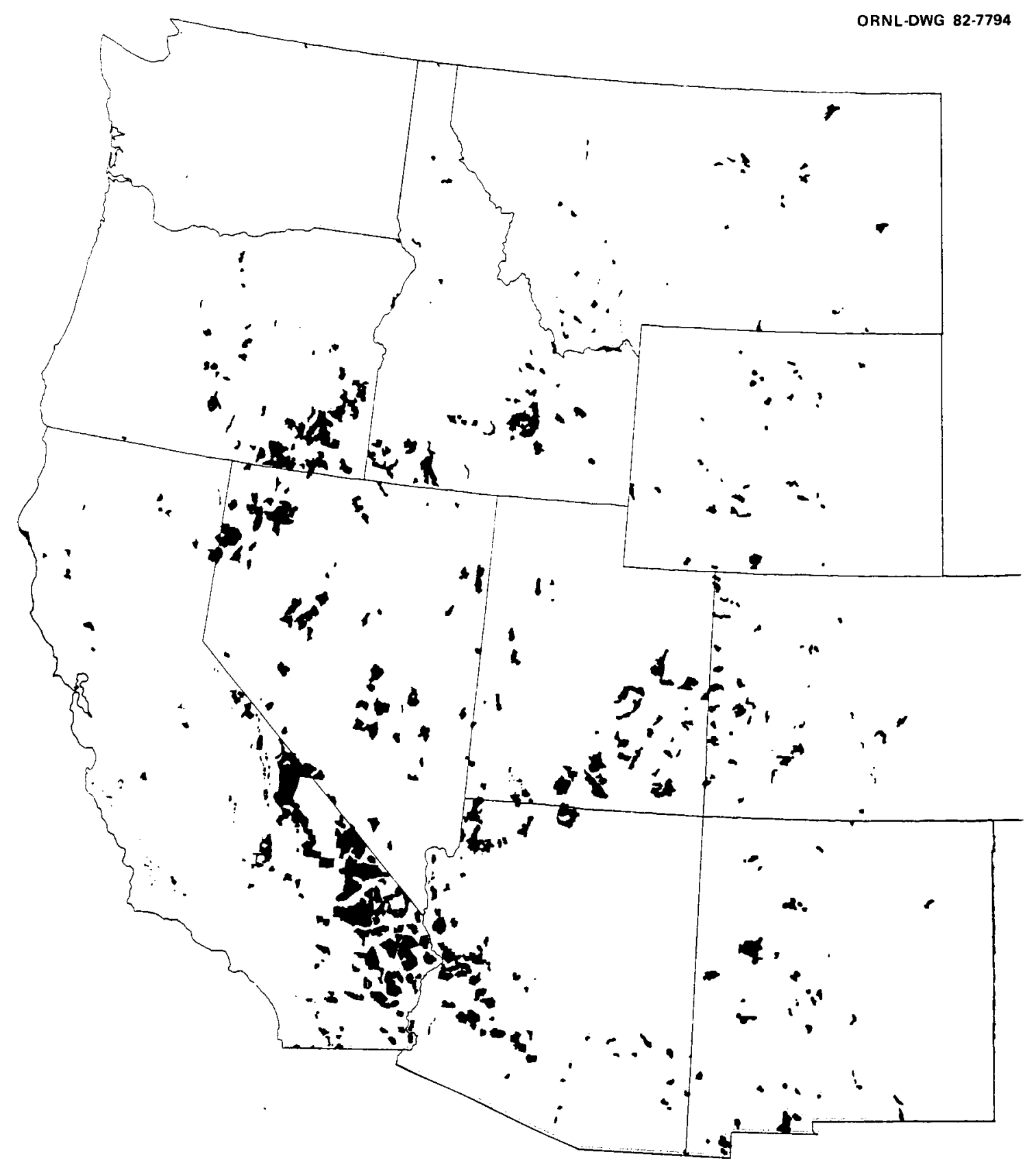

Fig. 3. The distribution of WSAs in the western United States as of Spring 1981. 
The boundary of each WSA was manually transferred to transparent acetate at a scale of $1: 2,500,000$ and then reduced photographically to the size of Figure 3. Because of this reduction in size, individual WSAs have not been labeled, and many apparently distinct WSAs on Figure 3 are actually clusters of two or more that, in detail, may be separated by roads.

\section{NOTE OF CAUTION}

The reader is cautioned that the apparent conflicts, or areas of coincidence, illustrated in Figures 4 through 7 may actually be slightly greater, or less, than suggested by these figures. This deviation is caused by slight variations in scale among the various data sets used to construct these figures. The problem can become particularly severe along the arbitrary boundaries of resource areas. Therefore, these figures should not be used to draw conclusions on the energy-resource potential of individual WSAs.

\section{COINCIDENCE BETWEEN WSAS AND AREAS OF IMPORTANT O]LL AND GAS POTENTIAL}

Figure 4 identifies those areas in the western United States that are estimated to have a high to moderate potential for undiscovered, recoverable oil and gas resources. The basis for assigning an area a high or moderate potential was subjective and comes largely from data in Dolton et a1. (1981). Small areas that clearly have no potential for oil and gas resources, such as basement uplifts in Cclorado and Wyoming, are not distinguished in the figure.

Recent estimates of undiscovered oil and gas resources by the U.S. Geological Survey (Dolton et a1. 1981) show the most important resource areas in the west to be (Figure 4): (1) the thrust belt in western 


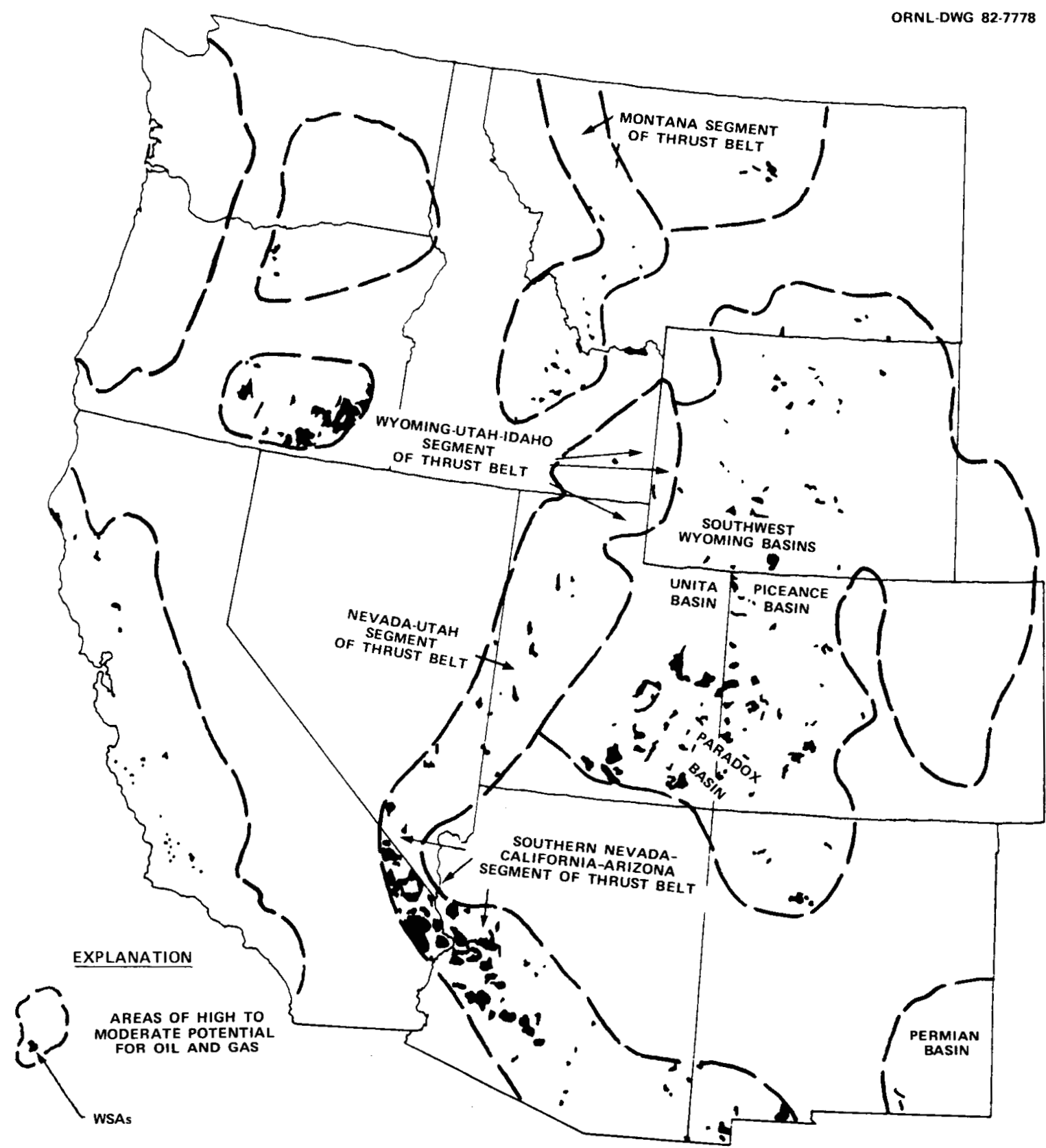

Fig. 4. The coincidence between WSAs and areas of high to moderate potential for oil and gas. 
Wyoming, northern Utah, and southeastern Idaho; (2) the thrust be1t in eastern Nevada and western Utah; (3) the basins of: southwestern Wyoming; and (4) the Permian Basin, only part of which is in the region under study in this report (New Mexico). Substantial gas resources are also estimated for the Uinta, Piceance, and Eagle Basins in Colorado, and for the thrust belt in Montana. The WSA-acreage in each of these highpotential areas, however, is relatively small (Figure 4). Other areas with a moderate potential for oil and gas, but in which many WSAs occur, include (Figure 4): (1) the Paradox Basin in eastern Utah and western Colorado; (2) the thrust belt in southern Nevada, southeastern California, and west-central Arizona; and (3) deep parts of the Columbia Plateau in southern Oregon.

Because of the large number and acreage of WSAs contained in these areas, we recommend that the BLM begin accelerated studies of these WSAs to determine their oil and gas potential and their suitability for wilderness recommendation. The other regions identified in Figure 4 as having high to moderate potential for oil and gas contain very few WSAs, and accelerated studies of the WSAs in these regions are not warranted.

\section{Quantitative Estimates}

We estimate that as much as 0.5 billion barrels of oil and 2.3 trillion cubic feet of gas might be contained in the 24.3 million acres of WSAs. This amount represents about $0.6 \%$ of our total undiscovered oil resources of 83 billion barrels and about $0.4 \%$ of our total undiscovered gas resources of 594 trillion cubic feet. These estimates were derived as follows: (1) the total acreage was calculated for each of 35 subprovinces and for parts of 4 additional subprovinces which comprise the 11 western states shown in Dolton et al. (1981); (2) the acreage of WSAs 
within each subprovince was estimated from the distribution and WSAacreage within each state as of November 1981 (personal communication to E. H. Oakes, December 16, 1981, BLM Wilderness Group, Washington, D.C.); (3) the percentage of WSA-acreage within each subprovince was calculated and multiplied by the total mean estimate for oil (and for gas) for that subprovince; and (4) oil and gas estimates for WSAs in each of the 39 subprovinces were totaled. (The raw data and calculations used to make these estimates are available on request.)

The most significant potential impacts to oil and gas resources are expected in the Paradox Basin of Utah and Colorado. According to Dolton et al. (1981), the Paradox Basin is estimated to contain 1.2 billion barrels of oil and 3.8 trillion cubic feet of gas, which represent about $1.5 \%$ of our undiscovered oil resources and about $0.6 \%$ of our undiscovered gas resources (mean estimates). From the outline of this region in Dolton et al. (1981), the Paradox Basin encompasses about 25 million acres of 1 and, of which $88 \%$ is estimated to be owned by the federal government (government ownership does not include Indian reservations). We estimate the WSA-acreage to be about 2.6 million, which is about $10 \%$ of the total area of this subprovince. Undiscovered resources assigned to WSAs in this subprovince may, therefore, amount to 120 million barrels of oil and 380 billion cubic feet of gas.

\section{COINCIDENCE BETWEEN WSAS AND AREAS OF IMPORTANT URANIUM POTENTIAL}

Figure 5 shows the coincidence of WSAs and areas of moderate to high potential for uranium resources. The information used to determine the most favorable uranium areas comes from DOF (1980b) and includes a11 resource areas assigned to DOE's speculative-, possible-, and probableresource categories. 


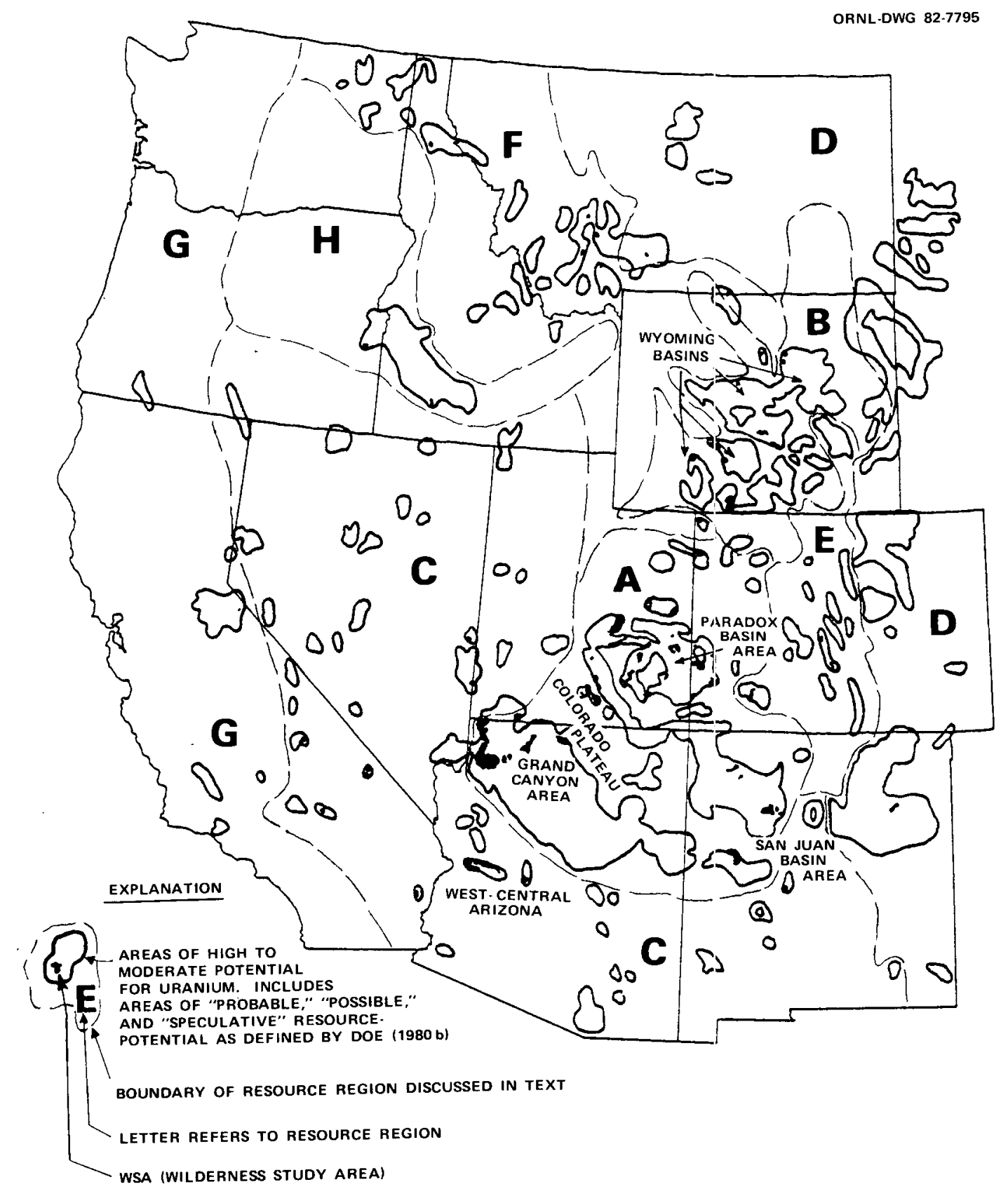

Fig. 5. The coincidence between WSAs and areas of high to moderate potential for uranium. 
By far the most important regions of uranium-resource potential (and production) in the United States are the Colorado Plateau and the Wyoming Basins (Figure 5). Relatively few WSAs in each region, however, coincide with areas of identified resource potential (compare Figure 3 with Figure 5). Nevertheless, these two regions contain the bulk of the nation's uranium reserves and resources (Table 5). Therefore, the uranium potential of WSAs in these regions and their suitability for wilderness designation, should be determined as soon as possible in the BLM planning process--particularly in the Paradox Basin (Figure 5). The only other area of significant coincidence is in west-central Arizona, where a new and potentially large uranium deposit has recently been described (Sherborne et a1. 1979).

\section{Quantitative Estimates}

We estimate that as much as 163,000 tons of uranium oxide might be contained in the 24.3 million acres of WSAs. This amount represents about $4 \%$ of our nation's total uranium resources of 3,781,000 tons [all estimates are based on the sum of the mean value for speculative-, possible-, and probable-potential resources, as estimated by DOE (1980b, p. 14)]. The uranium attributed to WSAs was derived by estimating the percentage of land occupied by WSAs in each of DOE's potential-resource areas within the major resource regions, such as the Colorado Plateau, the Basin and Range, and others, see Figure 5. This percentage was multiplied by the tonnage of potential resources assigned to the resource region by DOE (1980b). The result was then allotted to the WSAs within each resource region, as indicated in Table 9. [Letters before the name of the resource region on Table 9 correspond to letters on Figure 5; data from DOE (1980b, p. 14).] 
Table 9. Tonnage of uranium allotted to wilderness study areas

\begin{tabular}{lccc}
\hline $\begin{array}{l}\text { Resource } \\
\text { region }\end{array}$ & $\begin{array}{c}\text { Potentia1 } \\
\text { resources } \\
\text { (tons) }\end{array}$ & $\begin{array}{c}\text { Potential-resource } \\
\text { area occupied } \\
\text { by WSAs (\%) }\end{array}$ & $\begin{array}{c}\text { Resources } \\
\text { assigned } \\
\text { to WSAs } \\
\text { (tons) }\end{array}$ \\
\hline A. Colorado Plateau & $1,343,500$ & 0.07 & 94,045 \\
B. Wyoming Basins & 632,300 & 0.05 & 31,615 \\
C. Basin and Range & 415,900 & 0.05 & 20,795 \\
D. Great Plains & 302,500 & 0.01 & 3,035 \\
E. Southern Rockies & 236,300 & 0.03 & 7,089 \\
F. Northern Rockies & 191,200 & 0.03 & 5,736 \\
G. Pacific Coast & 20,500 & 0.01 & 612 \\
H. Columbia Plateau & 20,400 & 0.01 & 163,132 \\
Total & & & 205 \\
\hline
\end{tabular}

COINCIDENCE BETWEEN WSAS AND AREAS OF COAL RESERVES

Figure 6 shows the coincidence of WSAs and areas with high to moderate potential for coal development. The areas outlined by solid lines in Figure 6 are referred to as "known recoverable coal resource areas" (KRCRAs) that have been identified by the U.S. Geological Survey (BLM 1979b, p. 2-5). The KRCRAs represent the most likely places for future development of federal and nonfederal coal, and they include all public lands that contain coal with a moderate to high potential for development. Thus, essentially all WSAs with coal-development potential are illustrated in Figure 6. The dashed lines in Figure 6 outline the areas of coal-bearing rocks as defined by Trumbull (1960). In general, commercial quantities of coal from federal lands in these outlying parts 


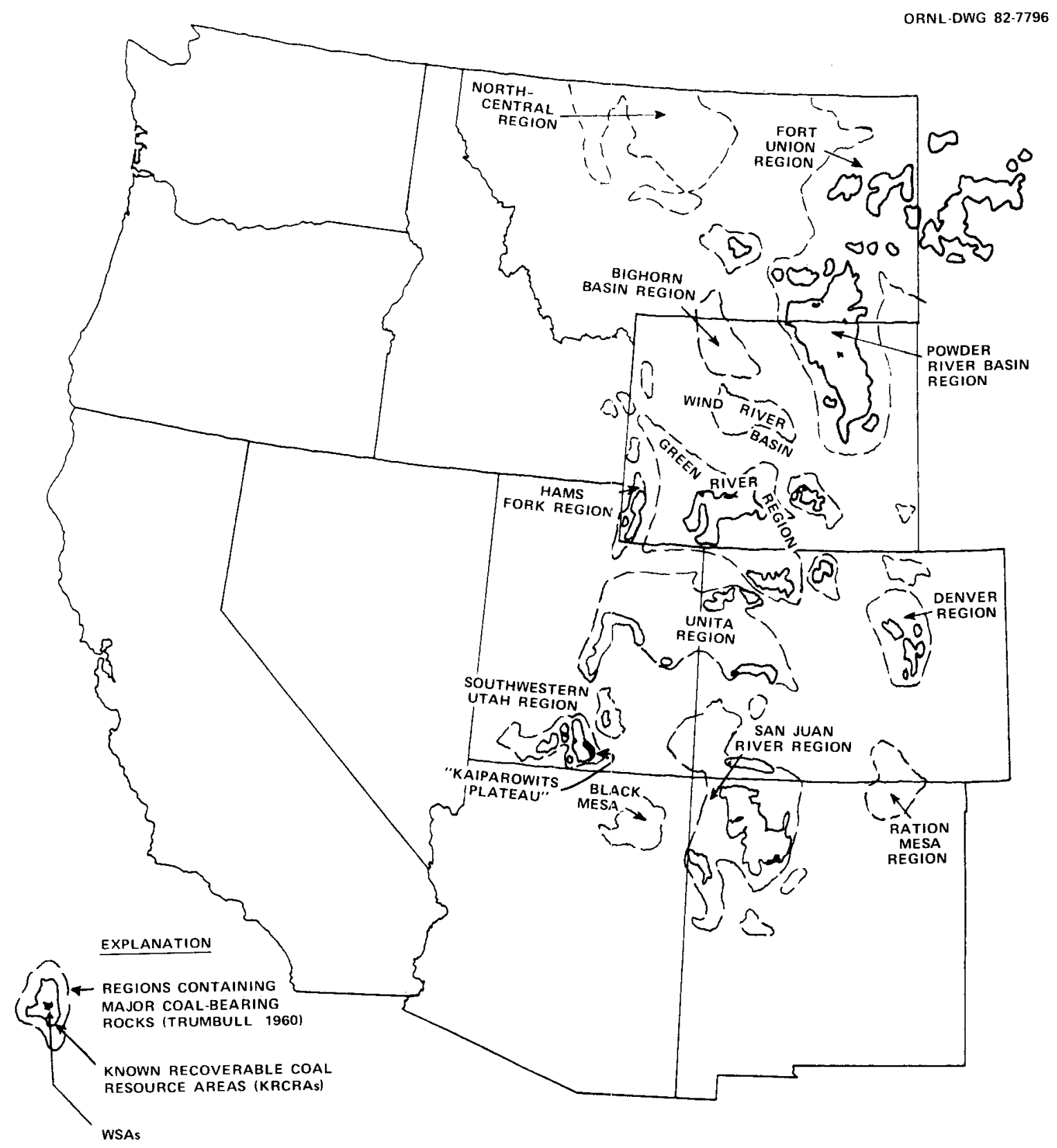

Fig. 6. The coincidence between WSAs and areas of high to moderate potential for coal development. 
of the coal basins are not available or, in a few cases, may not yet have been identified as KRCRAs by the U.S. Geological Survey. [According to the U.S. Geological Survey (personal communication to E. H. Oakes, December 1981, Conservation Division), an additional 5 million acres of KRCRAs have been identified by the U.S. Geological Survey since publication of the KRCRA-map contained in BLM (1979b). Therefore, some WSAs that are not shown on Figure 6 may be within these newly defined KRCRAs.]

As illustrated in Figure 6, few potential conflicts exist between KRCRAs and WSAs. The most significant apparent conflict is on the Kaiparowits Plateau in southwestern Utah. The inportance of this coal, however, is questionable because much of it cannot now be developed commercially. Furthermore, abundant and readily extractable coal is available from nearby areas, particularly in central Utah and northeastern Arizona. Other areas with minor potential conflicts include the San Juan Basin in New Mexico, the Green River Basin in southwestern Wyoming, and the Powder River Basin in Montana and Wyoming (Figure 6). The only area recommended to the BLM for accelerated study on the basis of potential conflicts between coal and WSAs is the Kaiparowits Plateau. [See Oakes et a1. (1981) for an evaluation and ranking of the energyresource potential of WSAs in southwestern Utah.]

\section{Quantitative Estimates}

We estimate that about 3 billion tons of coal may be contained in the 24.3 million acres of WSAs. This amount represents $0.7 \%$ of our nation's total coal reserve of 438 billion tous (see Table 6, footnote $\mathrm{g})$. The coal attributed to WSAs was derived by estimating the percentage of land occupied by WSAs within the KRCRAs shown in Figure 6, and by then multiplying this percentage by the total coal reserve for the 
region, as estimated by BLM (1979b, Chapter 1, p. 1-4, and Chapter 2, p. 2-3). [This estimate assumes that most of the coal reserve in each coal region defined in BLM $(1979 b)$ is contained in KRCRAs.] For the southwestern Utah/Uinta region, we estimate that WSAs cover $10 \%$ of the KRCRAs. The coal reserves in this region are estimated at 7.2 billion tons (BLM 1979b, p. 2-3); we therefore assigned 720 million tons of coal to WSAs in this region. For the San Juan Region, we estimate that WSAs cover $5 \%$ of the KRCRAs. Coal reserves in this region are estimated at 4.2 billion tons (BLM 1979b, p. 2-3); thus, 210 million tons of coal are allotted to WSAs in the San Juan Region. For the Green River/Hams Fork Region, we estimate that WSAs cover $5 \%$ of the KRCRAs. Coal reserves in this region are estimated at 15.5 billion tons (BLM 1979b, p. 2-3); thus, 780 million tons of coal are allotted to WSAs in this region. Finally, for the Powder River Basin Region, we estimate that WSAs cover only $1 \%$ of the KRCRAs. Coal reserves in this region are estimated at 142.5 billion tons (BLM 1979b, p. 2-3); thus, 1.43 billion tons of coal are allotted to WSAs in the Powder River Basin.

The total coal reserve assigned to WSAs in the four coal regions is 3.13 billion tons. Detailed investigations of the WSAs in these coal regions, however, would probably show that this estimate is too high because: (1) we have assumed, as mentioned previously, that the coal reserves in each coal region defined by BLM (1979b) are contained entirely within KRCRAs, (2) the WSA-acreage within each KRCRA is probably over-estimated, and (3) areas with important coal-development potential have generally been disturbed enough to preclude the establishment of WSAs; the scope and purpose of this study, however, precluded sitespecific analyses. 


\section{COINCIDENCE BETWEEN WSAS AND AREAS OF IMPORTANT GEOTHERMAL RESOURCES}

Figure 7 shows the distribution of geothermal resources in the western United States. The major types of geothermal resource within these areas include hydrothermal systems greater than $90^{\circ} \mathrm{C}$, possible contemporary magma chambers, and areas of high heat-flow (Blackwell 1978). The boundaries of the resource areas were drawn subjectively by determining the distribution of each resource type mentioned above. Much of the acreage within these regions, however, will have 1ittle, if any, geothermal potential. We have also plotted on Figure 7 the distribution of identified hydrothermal systems greater than $150^{\circ} \mathrm{C}$ (data from Blackwe11 1978). These are the only hydrothermal systems now known in the United States from which electrical energy could potentially be generated in the near future.

From a regional standpoint, the coincidence between WSAs and areas with moderate- to high-temperature geothermal resources is most apparent in northwestern Nevada and southeastern Oregon (Eigure 7). If many WSAs in this region were designated as wilderness by Congress, exploration for geothermal resources could be hampered because of restrictions imposed on data-gathering efforts such as drilling and seismic work. Overall impacts to the geothermal industry and to the public, however, would probably be minor because most of the currently identified hydrothermal systems in this region do not coincide with WSAs. Furthermore, the future potential for widespread use of even these known hydrothermal systems is uncertain at the present time.

\section{Quantitative Estimates}

We did not estimate the amount of geothermal energy that might be contained in the 24.3 million acres of WSAs because (1) the present 


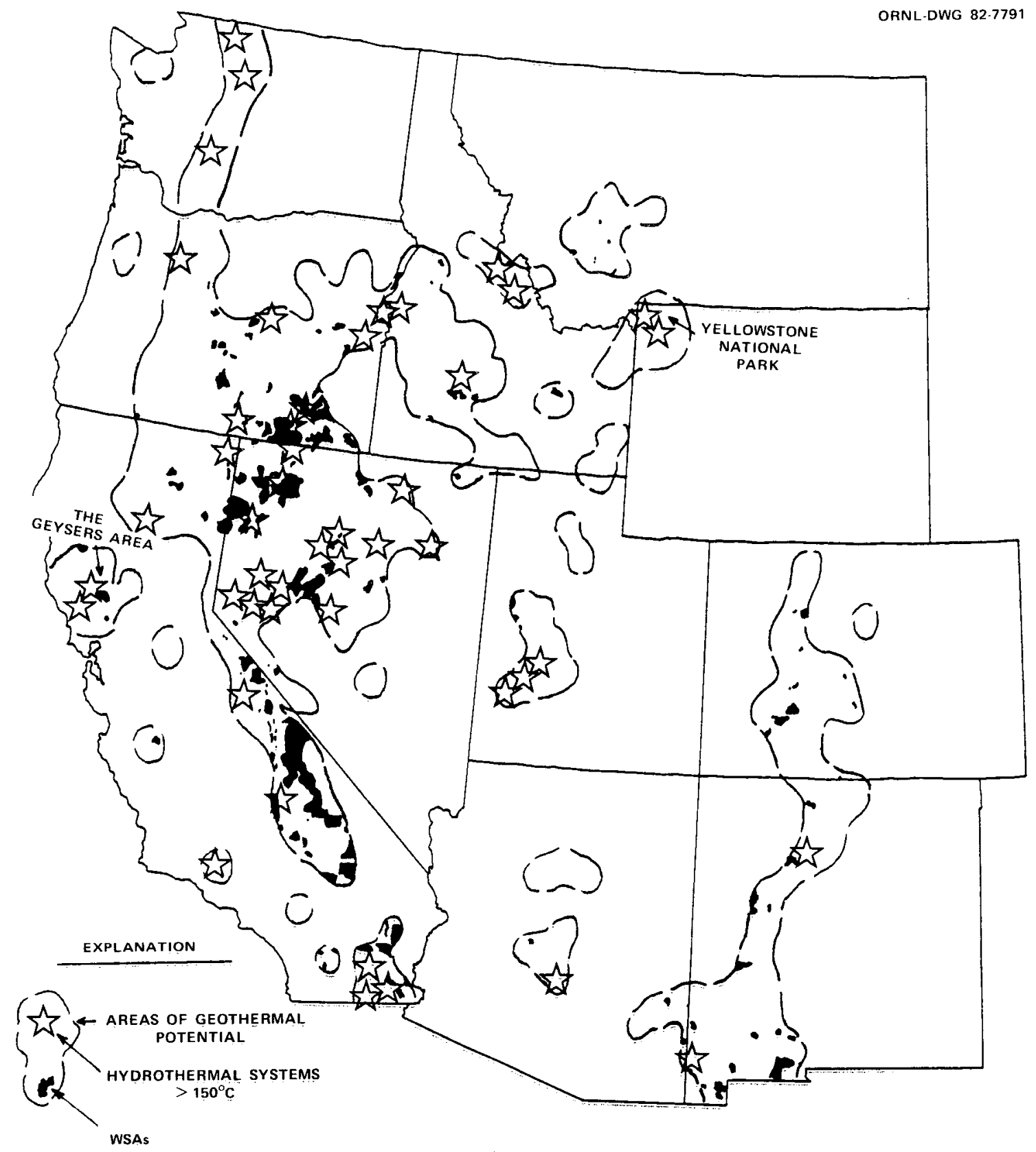

Fig. 7. The coincidence between WSAs and areas of geothermal resources. 
understanding of the nature and distribution of geothermal resources is inadequate, and (2) the use of moderate- to high-temperature hydrothermal systems has yet to be demonstrated commercially. An estimate of the geothermal energy in WSAs would therefore convey to the reader an inaccurate sense of certainty concerning exploitation of this resource. Nevertheless, it seems unlikely that the current distribution of WSAs, and the eventual inclusion of some WSAs in the National Wilderness Preservation System, will have any severe impacts to potential geothermal developments during the next several decades.

COINCIDENCE BETWEEN WSAS AND AREAS OF HYDROELECTIRIC POWER RESOURCES

No text figure was compiled to illustrate the coincidence between WSAs and hydroelectric power resources [see FERC (1979) for site-specific identification of potential hydropower sites in the West]. In our judgment, the overall degree of coincidence is minor because most WSAs are within arid regions that have essentially no potential for hydroelectric power. Moreover, the preponderance of those western federal lands estimated in Table 8 to contain $21 \%$ of the nation's hydroelectric power potential are probably under the jurisdiction of the U.S. Forest Service rather than the BLM. Those WSAs that contain flowing streams are generally very inaccessible, and the discharge of the streams is usually negligible. Some exceptions no doubt exist, hut these must be identified on a tract-specific basis.

\section{Quantitative Estimates}

We believe that the BLM wilderness review program will preclude from development much less than $1 \%$ of the estimated hydroelectric power potential of the nation (see Table 8). Even if the 24.3 million acres of 
genera11y arid WSAs had an average hydroelectric power potential (about 0.0002 megawatts/acre in the 11 western states, as calculated from data in Table 8, and using a total area of 760 million acres), the cumulative hydroelectric power potential of WSAs would be about 4860 megawatts, or $1.4 \%$ of the total hydroelectric power potential of the nation (Table 8). As described earlier, however, WSAs generally occur in areas in which there is little flowing water. We have therefore reduced (arbitrarily) their total overall potential by $75 \%$ to 1200 megawatts, or $0.3 \%$ of total U.S. hydroelectric power potential.

\section{SUMMARY}

On the basis of the areal distribution of energy-resource potential and the distribution of WSAs in the West, we identified several regions in which important energy-resource potential coincided with large acreages and numbers of WSAs (Figures 4 through 7). These regions were then combined into one map, illustrated in Figure 1. The wilderness suitability of WSAs within each region should be determined by the BLM as soon as possible so that those WSAs found to be unsuitable are eventually released for multiple-use purposes.

The estimated energy-resource potential of the 24.3 million acres of WSAs is summarized in Table 10. (We consider the percentages to be reasonable upper limits; the energy-resource potential of individual WSAs can be determined only through systematic district-level evaluations.) From an overall standpoint, the total acreage of WSAs has an energyresource potential somewhat lower than expected. For example, WSAs constitute about $0.8 \%$ of the total area (onshore and offshore) of the United States, but their oil and gas potential is estimated at only $0.6 \%$ and $0.4 \%$, respectively, of total U.S. undiscovered oil and gas resources. 
For the other resources, the WSA-acreage is compared with the total resource-potential for onshore areas only, of which WSAs represent about $1 \%$ of the area. On1y undiscovered uranium resources assigned to WSAs are estimated to be greater than $1 \%$ of total U.S. resources (4\%), whereas the coal reserves and the hydroelectric power potential of WSAs are estimated at $0.7 \%$ and $0.3 \%$, respectively, of total U.S. potential.

Table 10. Energy-resource potential of WSAs in the West ${ }^{a}$

\begin{tabular}{ll}
\hline Commodity & U.S. resource potential \\
\hline $0 i 1$ & $0.6 \%$ (about 0.5 billion barrels) \\
Gas & $0.4 \%(2.3$ trillion cubic feet) \\
Uranium & $4.0 \%(0.16$ million tons uranium oxide) \\
Coa1 & $0.7 \%(3$ billion tons of reserves $)$ \\
Geotherma1 & No estimate \\
Hydroelectric & $0.3 \%(1200$ megawatts $)$ \\
\hline
\end{tabular}

asee Table 2 for details and references.

From a geological standpoint it is impossible for these resources to be distributed evenly throughout the $24.3 \mathrm{million}$ acres of WSAs. Thus, only some WSAs will be important as a potential future-source of energy resources. Moreover, we believe it is reasonable to assume that only a part of the total WSA-acreage will ultimately be included in the National Wilderness Preservation System. Those WSAs not recommended for wilderness will probably become available for multiple-use purposes. 


\section{REFERENCES}

AIPG, 1981, Metals, minera1s, mining: American Institute of Professional Geologists, Golden, Colorado, 36 p.

Blackwe11, D. D., 1978, Heat flow and energy loss in the western United States, in Cenozoic Tectonics and Regional Geophysics of the Western Cordillera: Geological Society of America, Memoir 152, p. 175-208.

BLM, 1978, Wilderness inventory handbook: U.S. Department of the Interior, Bureau of Land Managenent, $30 \mathrm{p}$.

BLM, 1979a, Interim management policy and guidelines for lands under wilderness review: U.S. Department of the Interior, Bureau of Land Nanagement, $32 \mathrm{p}$.

BLM, 1979b, Final environmental statement, Federal Coal Management Program: U.S. Department of the Interior, Bureau of Land Management.

BLI, 1981, Public 1and statistics--1979: U.S. Department of the Interior, Bureau of Land Management, $183 \mathrm{p}$.

Bufe, C. G., 1982, Geothermal energy: Geotimes, February 1982, p. 37-39, American Geological Institute, Falls Church, Virginia.

Congressional Research Service, 1980, The energy factbook: House Document, 96 th Congress, $2 \mathrm{~d}$ Session, 809 p., U.S. Government Printing office, Washington, D.C.

DOE, 1980a, Annual report to Congress, 1979, volume three--synopsis: j.S. Department of Energy, DOE/EIA-0173(79)/3(SYN), 28 p.

DOF, 1980b, An assessment report on uranium in the United States of America: U.S. Department of Energy, Grand Junction Office Report no. GJO-111(80), 150 p.

DOF, 1981a, Statistical data of the uranium industry: U.S. Department of Energy, Grand Junction office Report No. GJO-100(81), 91 p.

DOE, $1981 \mathrm{~b}$, Geothermal progress monitor \#5: U.S. Department of Energy, $\mathrm{DOE} / \mathrm{CE}=0009 / 5,93 \mathrm{p}$.

Dolton, G. L., et a1., 1981, Estimates of undiscovered recoverable resources of conventionally producible oil and gas in the United States: U.S. Geological Survey, Open-File Report 81-192, 17 p.

EIA, 1981a, U.S. crude oil, natural gas, and natural gas liquids reserves--1979 Annual Report: J.S. Department of Energy, Energy Information Administration, DOE/EIA-0216(79), 101 p. 
EIA, 1981b, Demonstrated reserve base of coal in the United States on January 1, 1979: U.S. Department of Energy, Energy Information Administration, DOE/EIA-0280(79), 121 p.

FERC, 1979, Hydropower resource assessment maps: U.S. Department of Energy, Federal Energy Regulatory Commission, Washington, D.C., map scale $1: 500,000$.

Glass, G. B., 1981, A critical evaluation of published western coalresource estimates: Geological Society of America Bulletin, v. 92, p. 538-541.

Miller, B. M., et a1., 1975, Geological est:Lmates of undiscovered recoverable oil and gas resources in the United States: U.S. Geological Survey, Circular 725, 78 p.

Muffler, L. J. P., et a1., 1978, Assessment of geothermal resources in the United States: U.S. Geological Survey, Circular 790, 163 p.

Oakes, E. H., et a1., 1981, Energy-resource evaluation of Wilderness Study Areas--the Bureau of Land Management's Cedar City District, Utah: Submitted to the U.S. Department of Energy on 4/81, 317 p.

Porter, Edward, 1980, The use of federal lands for energy development: U.S. Department of Energy, Energy Information Administration, DOE /EIA-0201/8, 104 p.

Sherborne, J. E., Jr., et al., 1979, Major uranium discovery in volcaniclastic sediments, Basin and Range province, Yavapai County, Arizona: American Association of Petroleum Geologists Bulletin, v. 63 , no. 4 , p. 621-646.

Trumbu11, James, 1960, Coal fields of the United States: U.S. Geological Survey, map scale $1: 5,000,000$.

U.S. Army Corps of Engineers, 1979, National hydroelectric power resources study--Preliminary inventory of hydropower resources: U.S. Army Corps of Engineers, v. 2. (Ju1y 1979).

USGS, 1965, United States of America, showing the extent of public land surveys, remaining public land, historical boundaries, national forests, Indian reservations, wildlife refuges, national parks and monuments: U.S. Geologica1 Survey, 1965, nap scale 1:2,500,000.

USGS/USBM, 1980, Principles of a resource/reserve classification for minerals: U.S. Geological Survey, Circular 831, 5 p.

Z1mmerman, C. F., 1979, Uranium resources on federal lands: Lexington Books, D.C. Heath \& Company, Lexington, Massachusetts, 376 p. 


\section{APPENDIX}

\section{CURRENT AND FUTURE AVAILABILITY \\ OF FEDERAL ONSHORE LANDS \\ IN THE WESTERN UNITED STATES \\ FOR MINERAL ACTIVITY}

\section{INTRODUCTION}

As demonstrated in Part 1 of this report, federal onshore lands in the 11 western states (the West) now contribute about 8 quads of energy, or $13 \%$ of our nation's domestic energy supply. Furthermore, these lands have the potential to supply an even larger share of our domestic energy supply in the future. The actual future energy contributions made by these lands, however, will depend to some extent on their availability for mineral exploration and development. Unfortunately, there is widespread disagreement, especially between the minerals industry and environmental groups, about the amount of federal land that is "off limits" to mineral activities. In general, the minerals industry claims that from $70 \%$ to $75 \%$ of a 11 federal lands are effectively closed to mineral activities (AIPG 1981), whereas environmental groups claim that these percentages are much too high.

Because the BLM's wilderness review program has imposed additional restrictions on some federal lands--chiefly in the western United States--an up-to-date tabulation of the availability of these lands for mineral activities is relevant to this study. In addition to tabulating the current status of access, we have also estimated the future (1990) availability of western federal lands for mineral activities on the basis of present land-use recommendations in Congress and on current trends in federal land management. 


\section{SCOPE AND METHOD OF STUDY}

This appendix examines the access to federal onshore lands in the West for leasable and locatable minerals. Lands for which the government owns only the mineral estate are not included; thus, the federal lands evaluated in this study total 358.8 million acres, or about $47 \%$ of the area of the 11 western states. To be consistent with Parts 1 and 2 of the study, we specifically excluded Alaska and other parts of the country. (The precise acreage and distribution of federal lands in Alaska have not been completely determined, and the current land situation is exceedingly complex.)

This appendix was prepared by (1) reviewing and updating previous studies of federa1-land availability (see references), (2) contacting government employees, and (3) analyzing recent data provided by the major land-management agencies. The reader interested in detailed discussions of the various statutes, laws, and executive orders affecting federal lands is referred to OTA (1979, p. 331-369) and to Bennethum and Lee $(1975$, p. $37-47)$.

Our approach to this topic differs from that of other studies of federal-land availability. First, we chose to study only the West rather than the entire country for reasons described above. Second, we estimated the future availability of federal lands in the West for mineral activities. Although we expect some criticism of the section on future availability, we nevertheless believe that the current access to western federal lands by the minerals industry will change rapidly during the next 10 years. This information will, or at least should, be important to land-management decisions made during the next few years. 
The assignment of western federal lands to specific land-access categories in this report (such as "highly restricted" or "slightly restricted") was occasionally a matter of judgment. Wherever uncertainty existed about the access category to which these federal lands should be assigned, we always chose the more restricted category. Thus, the federal acreage that we consider to be: "effectively closed" to mineral activities in the West should be viewed as an upper limit. (The use of terms such as "effectively closed" and "highly restricted" are defined elsewhere in this appendix.)

FEDERAL LANDS IN THE WEST AND THE MINERAL LAWS

The total onshore area of the United States is about 2.3 billion acres. As of fiscal year 1979 (BLM 1981a), the federal government owned about one-third of this area (738 million acres), mostly in the West and in Alaska ( $49 \%$ of the federal lands are in the West, $44 \%$ are in Alaska, and $7 \%$ are in the remaining 38 states). According to Jackson (1981), near1y 70 federa1 agencies, commissions, and bureaus manage the federal lands, a1though $99 \%$ of these lands are administered by only 6 agencies. Table A.l summarizes the total acreage of land held by the major federal agencies in the United States, and the amounts and proportions held by these agencies in the West.

Most minerals underlying federal lands can be developed under the various mineral-leasing laws or the Mining Law of 1872; these laws are collectively referred to as the "mineral laws." Common construction materials such as stone, cinder, and gravel, are made available by the Surface Resources Act of 1955. The leasing laws apply to the fossil fuel minerals (e.g., oil, gas, coal, and oil shale), the chemical and fertilizer minerals (phosphate, potash, sodium, and in Louisiana and New 


\section{Table A.1. Acreage of Federal Land in the United States} and the West as of $1979^{\mathrm{a}}$

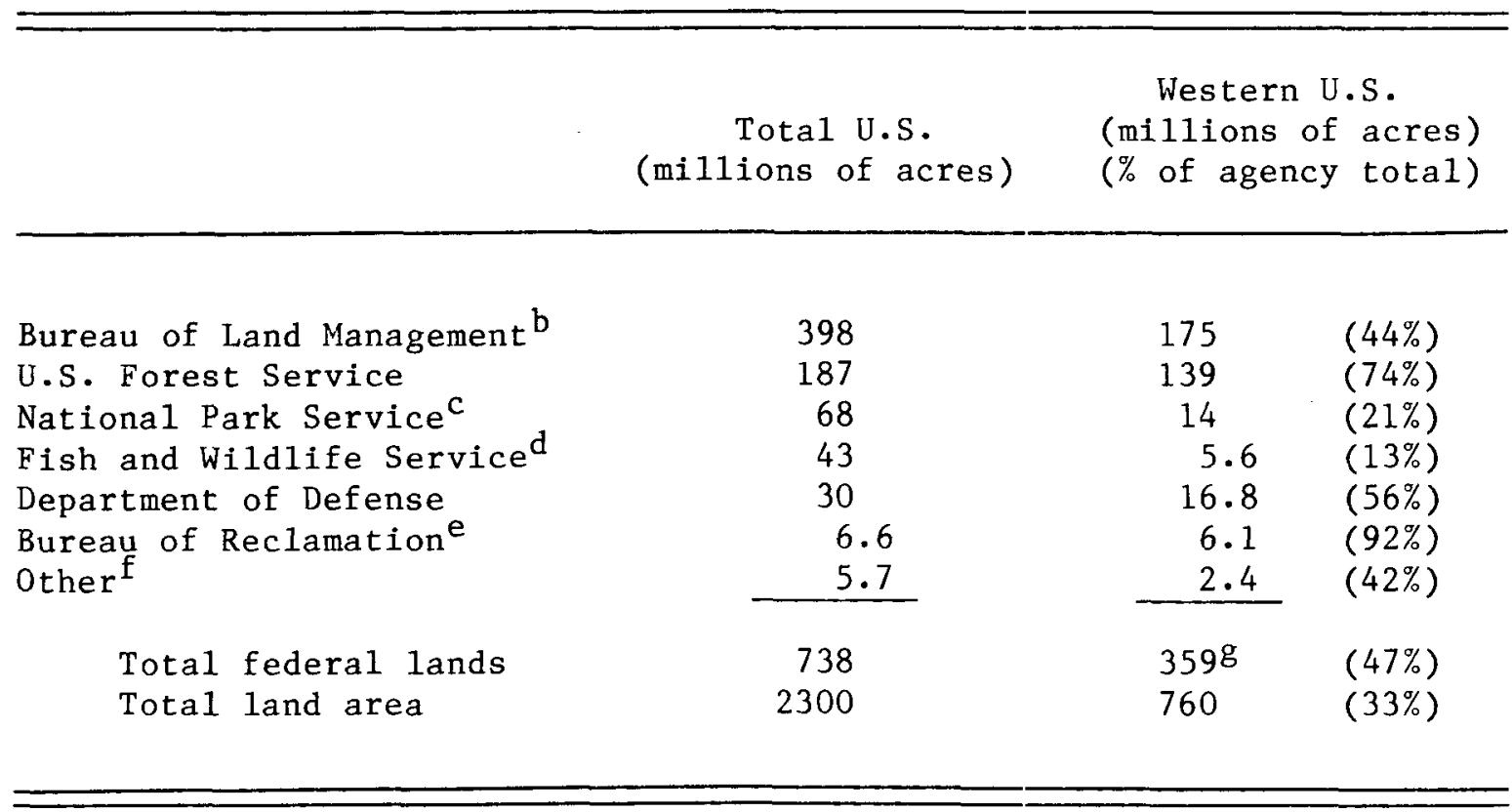

${ }^{a}$ Data compiled from BLM (1981a, Table 9). Western states include Washington, Oregon, California, Nevada, Idaho, Montana, Wyoming, Utah, Colorado, New Mexico, and Arizona.

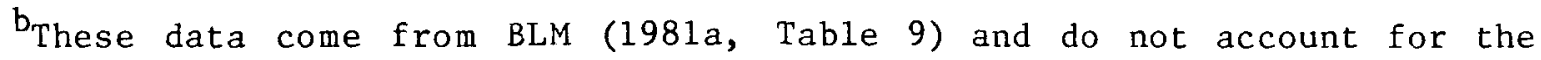
current land situation in Alaska.

${ }^{c}$ Data from BLM (1981a). As of Ju1y 1981, the National Park Service administered 81 million acres of land, about two-thirds of which are in Alaska (personal communication to E. H. Oakes, July 1981, John Vosburgh, National Park Service, Washington, D.C.).

d Data from BLM (1981a). As of December 1980, the U.S. Fish and Wildlife Service administered 88.8 million acres of land, of which 76 million acres are in Alaska (USFWS 1980; includes 3.8 million acres of easements and land used for secondary purposes).

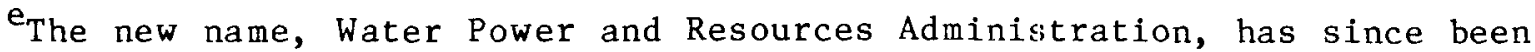
changed back to the Bureau of Reclamation.

f "Other" includes land administered by the U.S. Department of Energy, the Bureau of Indian Affairs, and many other agencies with much smaller amounts of federal land (BLM 1981a, Table 8, p. 10-12).

gof the 359 million acres of federal land in the western states, $4 \%$, or 13.4 million acres, has been acquired. 
Mexico, sulfur), and geothermal resources. Under the leasing laws, a private party can explore for and develop minerals underlying federal lands, but only if rentals and royalties are paid to the government. Under the Mining Law, which applies to all minerals not covered by other mineral laws (the locatable minerals, often referred to as the "hardrock minerals"), private parties have the right to enter federal lands to explore for and to develop minerals by locating and then staking a mining claim. No rentals or royalties are paid to the government. If the claim is unpatented, title to both the surface and subsurface remains with the government. If the claim is patented, the land is no longer part of the federal domain. Since the late 1960s, however, very few mineral patents have been issued by the government (Sheridan 1977).

Many exceptions exist to this general discussion of the mineral laws. The major exception is that minerals usually disposed of under the Mining Law are leased on acquired federal lands. In the West, 13.4 million acres, out of a total federal area of 358.8 million acres, have been acquired by the government as of fiscal year 1979 (BLM 1981a, p. 9). For a detailed discussion of the mineral disposal systems for federal onshore lands, see OTA (1979, p. 103-172).

PREVIOUS AND CURRENT STUDIES ON THE AVAILABILITY OF FEDERAL LANDS FOR MINERAL ACTIVITIES

Numerous studies have attempted to tabulate and classify the acreage of federal onshore lands that are available for mineral activities. The results of some of these studies are listed in Table A.2.

Direct comparison of the results of these studies can be misleading. Some studies were compiled with data from the mid-1970s (DOI 1976; OTA 1976 and 1979), whereas others used more recent data that reflect changes 
Table A.2. Results of Previous and Current Studies of Federal-Land Availability for Mineral Activities

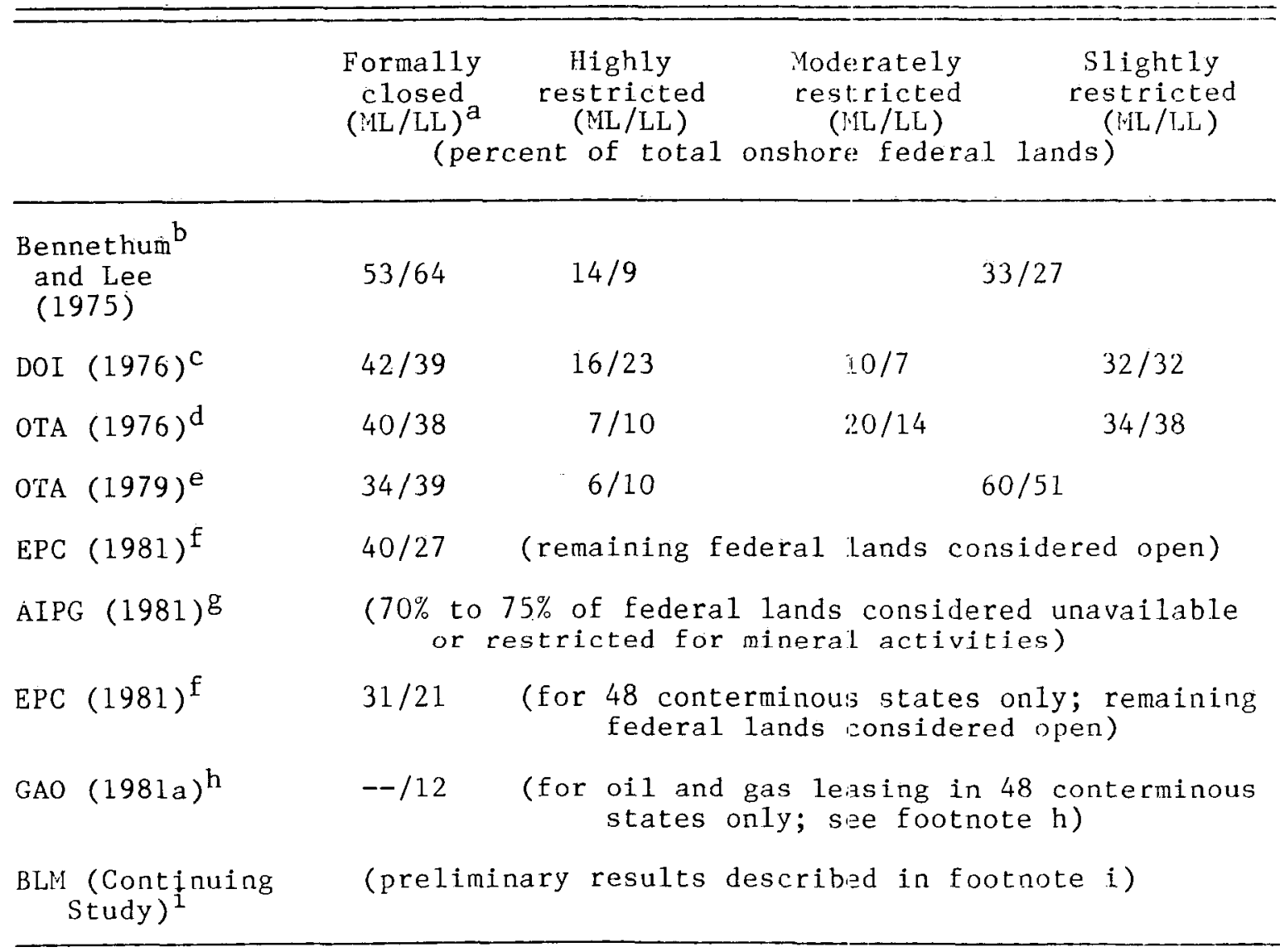

$a_{M L}=$ Mining Law; LL = Leasing Laws.

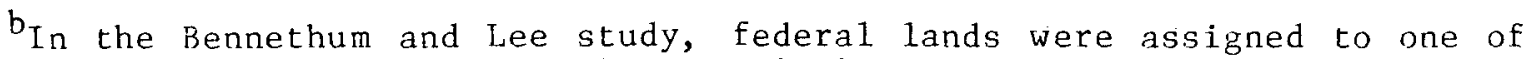
three categories: (1) withdrawn, which corresponds for the most part with the formally-closed category; (2) limited, or what Bennethum and Lee called de facto withdrawals, which correspond largely to the highlyrestricted category; and (3) open (Bennethum and Lee considered an unknown part of the open lands to be closed to leasing because of special land-use plans by the major land-management agencies).

$c_{U}$.S. Department of the Interior (DOI 1976).

d Office of Technology Assessment (OTA 1976).

effice of Technology Assessment (OTA 1979). In this study, OTA combined the moderately- and slightly-restricted categories into one category and considered the lands assigned to this category to be "generally open to mineral activity, although there will usually be some requirements to mitigate the mineral activity's impact on the surface resources" (OTA 1979 , p. 336). 
Table A.2 (continued)

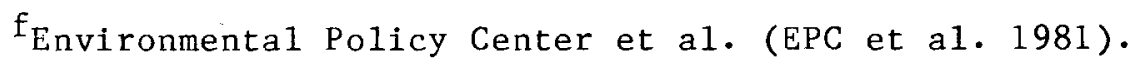

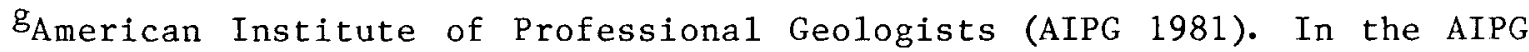
report it is not clear what is meant to be conveyed by the word "restricted" in the following quote (p. 4): "roughly 70 to 75 percent of the 750 million acres [of federal land] is unavailable or restricted for exploration and mineral development." We interpret this to mean that AIPG considers roughly two-thirds of all federal lands to be effectively closed to mineral activities at the present time.

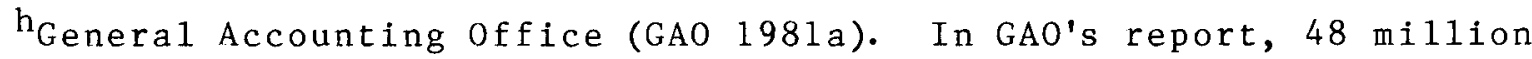
acres, or $12 \%$ of the 411 million acres of federal land in the 1ower-48 states, were considered to be formally closed to oil and gas leasing. Another 16 million acres were closed by informal administrative actions in the five states reviewed specifically for this type of withdrawal in the GAO study. Because administrative closures were not tallied for other states, we decided not to enter the 16 million acres under the highly-restricted category in this table because it would convey to the reader the unwarranted impression that GAO's study tallied all administrative withdrawals.

$i_{\text {The BLM is now in the process of inventorying withdrawn and classified }}$ federal lands in the 11 western states, as directed under the Federal Land Policy and Management Act of 1976. Preliminary results, as of October 16, 1981, indicate that 6164 withdrawal orders and 1195 land classifications remain in effect in the West (written communication to E. H. Oakes, December 1981, BLM's Withdrawa1s, Lands, and Rights-of-Way Group). Combined, the withdrawal orders and classifications formally close 35.5 million acres of western federal land to mineral location and 15 million acres to mineral leasing and location. The BLM's figures, however, do not include lands under the jurisdiction of the Department of Agriculture (in particular, the U.S. Forest Service) or the Department of Defense. Furthermore, the figures gathered by BLM to date are gross acreages; thus, the federal acreage closed by each separate withdrawal order may, in some instances, apply to (overlap) the same federa1 land.

If the formally closed lands administered by the U.S. Forest Service and the Department of Defense (as determined by us; Tables A.3 and A.4) are added to the BLM's acreage figures cited in the paragraph above, federal lands closed to mineral location in the West would total 53.6 million acres, whereas 17.4 million acres would be closed to mineral leasing. Compared with our results in Table A.4, these 53.4 million acres represent only $1 \%$ more western federal land being formally closed to mineral location than was estimated by us in Table A.4 ( 53.4 million acres compared with 48.7 million acres, out of a total federal acreage in the West of 359 million). For lands formally closed to leasing and location, the 17.4 million acres cited above represent $1 \%$ less than the 21.5 million acres estimated in Table A. 3 to be formally closed to mineral leasing. 
in federal-land availability since the mid-1970s (GAO 1981a; EPC et a1. 1981; and the continuing review by BLM). Also, the scope and purpose of these studies, as well as the definition of what constituted a land withdrawal, usually varied. In general, however, these studies found that between one-third and one-half of all federal lands in the entire United States were formally closed to mineral. leasing and hardrock mineral location in the mid-1970s. (The results of most of these studies are not comparable with our study because we did not include Alaska).

The availability of federal lands that were assigned to the highlyrestricted and moderately-restricted categories in Table A.2 is a matter of judgment. This is demonstrated by contradicting conclusions drawn in studies by DOI (1977) and OTA (1979). For example, DOI (1977, p. 43) stated that "the specific conclusion (from DOI's 1976 study and OTA's 1976 study) is that mineral exploration and development are prohibited, severely restricted, or moderately restricted on two-thirds of all federal lands." DOI (1977) therefore considered federal lands assigned to the moderately-restricted category in the earlier DOI and OTA studies to be effectively closed to mineral activities. The more recent oTA study (1979, p. 336), however, combined the moderately-restricted and slightly-restricted categories (see Table A.2) and considered the lands assigned to this category to be "generally open to mineral activity" (p. 336). OTA therefore considered only about 40\%, rather than twothirds, of the nation's federal lands to be effecively closed to mineral location and about one-half to be effectively closed to mineral leasing. The reader can only conclude that the acreage of federal land that is effectively closed to mineral activities depends largely on the significance ascribed by each author to the "moderately-restricted" category. 
Regardless of the year, or the purpose and methods by which these studies were conducted, each author faced a similar problem: the record of land withdrawals kept by the federal goverment is incomplete, and much of the available information is not centralized. The BLM's current review of land withdrawals will attempt to remedy this situation by centralizing and computerizing the record of withdrawals and restrictions imposed on federal lands (see Table A.2, footnote $i$ ). Nevertheless, many years are expected to pass before the net acreage of withdrawn federal land is accurately known. The OTA (1979, p. 331) study apt ly characterized the situation as it existed in the mid-1970s, and this statement is still valid today:

"The information necessary to produce an accurate aggregate analysis [of the availability of federal lands for mineral activity] exists only in raw form in local agency records, and neither the BLM nor any other agency has any programs or procedures for gathering, compiling, and analyzing such information, which would seem to be indispensable for comprehensive minerals and land management.

At the present, therefore, any attempt to construct an overall picture of Eederal mineral land availability must rely on whatever data is available or can be constructed from secondary sources......"

This situation does not invalidate the results of land-availability studies, but, because of the broad generalizations and assumptions that must be made, it does reduce the absolute certainty or accuracy of the results. We nevertheless believe that for sound land-use planning, federal land managers must be provided with at least an estimate of the current and future availability of federal lands for mineral activities.

\section{USE IN THIS STUDY OF THE TERMS WITHDRAWAL, EFFECTIVELY CLOSED, AND OPEN}

As used in this study, a withdrawal indicates that the restrictions imposed on federal land are considered severe enough at the present time to preclude economical and/or thorough mineral exploration and potential 
development. The definitions of the three land-access categories used in this report are listed below; these categories are generally similar to those in OTA (1979, p. 335-336). Except for lands assigned to the formally-closed category, sharp distinctions between the land-access categories do not exist.

o Lands that are "formally closed" to mineral activities exp1icitly prohibit, by statute or land order, all mineral exploration and development. Examples include most Nationa1 Park Service lands and some military lands. Federal lands that are formally closed to mineral activities are relatively easy to identify, although the acreage closed as a result of power-site withdrawals, watershed protection, and water holes, for example, can be estimated only roughly.

- Lands that are "highly restricted" are legally open to mineral activity, but are subject to statutory and administrative conditions that greatly discourage mineral activity. Examples include existing wilderness areas, wildlife refuges, and some scenic and recreation areas.

- Lands that are "moderately or slightly restricted" are considered to be open to mineral activities, although there are usually requirements to mitigate the adverse impacts of mineral exploration and development (standard or normal stipulations), or the land may be closed to development of certain minerals.

For this study, we consider lands assigned to the formally-closed and highly-restricted categories to be effectively closed to mineral activities. Lands assigned to the moderately- or slightly-restricted categories are considered open to mineral activities. As stated in OTA (1979), the overall impact to mineral activities, even in withdrawn areas, may be less than expected because valid leases and claims that existed before the land was withdrawn can legally be developed, although under strict controls.

The restrictions imposed on mineral activities on federal lands range from formal to informal, from national to local, and from complete to slight. The formal restrictions are broadly grouped into three types: classifications, withdrawals, and reservations (DOI 1977, p. 10). A 
"classification" segregates federal land for disposition under a particular statute, which may or may not be a mineral statute. Thus, some classifications may restrict access to federal lands for mineral activities, or the statute may close some federal lands to specified minerals only. A "withdrawal" can segregate federal land from any one or a11 of the public land laws. Thus, federal lands that are withdrawn may or may not be closed to mineral activities. A "reservation" dedicates the federal land to a particular purpose or use, such as a wildife refuge, Indian lands, or a national forest. Each of the three types of formal segregations can restrict, to varying degrees, the level of mineral activities allowed on federal lands. The land orders that segregate federal lands are published in government reports and are subject to public scrutinty.

In contrast to the formal restrictions, informal or ad hoc decisions made by local land managers can also restrict access to federal lands (these are sometimes called administrative or de facto withdrawals, and they are described in more detail in the next section). These decisions are usually not subject to critical review, nor are they necessarily identified in land-status records that are kept at local land-management offices. The lands they affect are therefore very difiicult to identify. As genera11y used in studies on this topic, classifications, withdrawals, and reservations, as well as local and/or informal restrictions that either formally close or limit access to federal lands for mineral activities, are collectiveluy referred to as land withdrawals.

In their study of the availability of federal lands for mineral activities, EPC et al. (1981) defined a withdrawal on a strictly legal basis. Federa1 lands were assigned to one of two groups--legally open or legally closed to mineral activities (Table A.2). For example, existing 
and potential wilderness areas were considered to be open to mineral leasing and location because, by law, mineral activities that do not adversely affect the wilderness characteristics of these lands are allowed (BLM 1979). Many studies, however, recognize three or four degrees of restrictions on federal lands (Table A.2). The minerals industry often points out, for example, that many areas that are legally open to mineral activities are in reality effectively closed because of: (1) special lease and permit stipulations that make exploration less attractive, (2) delays in the processing of applications, and (3) arbitrary administrative decisions that amount to de facto withdrawals. Currently, there is no general agreement regarding how a withdrawal should be defined in terms of its restrictiveness to mineral activities. Furthermore, for those studies that have used three or four degree-ofrestriction categories (e.g., highly-restricted, moderately-restricted), no guidelines exist for assigning lands to these categories.

\section{THE PROBLEM OF OVERI.APPING AND ADMINISTRATIVE WIT'HDRAHALS}

A serious concern in tabulating statistics on federa1-land avai1ability is that of overlapping withdrawals. For example, a local land manager may effectively withdraw an area from mineral activities; after many years, much of the same area may be withdrawn from mineral entry for other reasons. The net acreage of withdrawn land may not have changed over the years, but an investigator might add the acreage of both withdrawals and conclude that more withdrawn land exists in the district than is actually the case. Consider the example of lands within the National Wilderness Preservation System. The acreage of existing wilderness areas is tallied and assigned to a highly-restricted category for mineral activities. Wilderness areas in National Parks must then be subtracted from the total wilderness acreage because National Park Sevice lands are, 
in most cases, already accounted for in the formally-closed category. A1though every attempt was made in this report to account for overlaps, some double- and triple-counting has probably occurred.

Overlapping withdrawals are also a problem in the BLM's withdrawal review program (personal communication to E. H. Oakes, December 1981, BLM's Withdrawals, Lands, and Rights-of-Way Group). For example, 11 withdrawal orders covering 1.7 million acres of federal land in Arizona were recently revoked by the Reagan administration. of this area, only 40 thousand acres were actually reopened to mineral location, because other overlapping withdrawals remain in effect.

In all studies of federal-1and availability, the acreage assigned to the various land-access categories reflects policies and decisions that are applied fairly uniformly throughout the nation. Local policies and ad hoc decisions by district land managers that restrict access to federal lands are commonly not taken into account. Un1ike the overlapping withdrawals, which tend to increase the apparent acreage of withdrawn land, administrative withdrawals, if unaccounted for, tend to underestimate the actual acreage of withdrawn land. Administrative withdrawals (called de facto withdrawals by some) are characterized by any decisions and actions by a land manager that restrict access to federal lands to such a degree that thorough mineral exploration and potential development are uneconomical and/or greatly discouraged. For example, a local BLM land manager may decide that an area will not be leased because of special scenic and recreational values, or may restrict access to a lease during part of the year because of special wildlife considerations. Moreover, even if mineral leases are granted, special stipulations can be imposed on the lease that discourage mineral exploration and development in some areas and/or under certain conditions (e.g., a lease stipulation 
such as no surface occupancy). Even under the Mining Law, access to federal lands can be delayed (not denied) because of pending environmental studies, or access can be severely restricted because of strict enforcement of surface-management regulations.

Administrative withdrawals are difficult to quantify reliably because they are rarely identified in an agency's land-status records; nor are they subject to critcal review. We have nevertheless made a rough estimate of administrative withdrawals in the West based on data in GAO (1981a) (see the extended discussion in footnote $j$ of Table A.3). It is reasonable to suspect, however, that some part of the 13.6 million acres of administrative withdrawals listed on Table A.3 and A.4 is already tabulated in other parts of the highly-restricted category. Thus, the reader should consider our estimate of administrative withdrawals to be an upper limit.

\section{RESULTS}

Tables A.3, A.4, and A.5 contain the results of this study. The current status-of-access to western federal onshore lands is shown for the leasable minerals in Table A.3, and for the locatable minerals in Table A.4. Table A.5 shows the estimated status-of-access by 1990 for both the leasable and locatable minerals.

Placing administrative withdrawals in the West at 13.6 million acres, we estimate that, in late $1981,6 \%$ of the West's federal land was formally closed to mineral leasing, $38 \%$ was highly restricted, and $56 \%$ was open with only moderate or slight (normal) restictions. For the locatable minerals, $14 \%$ of the West's federal land was formally closed, $32 \%$ was highly restricted, and $54 \%$ was open with only moderate or slight restrictions. Stated another way, we estimate that $44 \%$ of the federal 
land in the West was effectively closed to mineral leasing and $46 \%$ was effectively closed to mineral location (these percentages represent the sum of the formal1y-closed and highly-restricted categories for the leasable and for the locatable minerals; see Tables A.3 and A.4).

During the next 10 years, the availability of western federal lands for mineral activities is expected to increase significantly, as indicated in Table A.5. For the leasable minerals, we estimate that $15 \%$ of the West's federal land will be formally closed, $17 \%$ will be highly restricted, and $68 \%$ will be open with only moderate or slight (normal) restrictions. For the locatable minerals, we estimate that $23 \%$ of the federal land in the West will be formally closed, $10 \%$ will be highly restricted, and $67 \%$ will be open with only moderate or slight restrictions. These increases will result largely from: (1) the release of about 27.1 million acres of land recommended for nonwilderness during the RARE-II program; (2) the release of part of the 7 million acres assigned to the further-planning category during the RARE-II program (estimated at 3.5 million acres for this study); (3) the release of part of the 24.3 million acres of WSAs now under wilderness review by the BLM (estimated at 12.2 million acres for this study); and (4) the release of many millions of acres of federal land (by the Reagan administration) as a result of accelerated review and revocation of antiquated. withdrawal orders (see Table A.5). The amount of additional federal land to be withdrawn during this 10-year period, over and above that already listed on Tables A.3 and A.4, is expected to be only a few million acres, and to be primarily by administrative actions (see Table A.5). 
Table A.3. Availability of Federal Onshore luands in the Western United States $^{a}$ for Leasable Minerals ${ }^{b}$ as of 1981

\begin{tabular}{|c|c|c|c|}
\hline & $\begin{array}{l}\text { Formally } \\
\text { closed }\end{array}$ & $\begin{array}{l}\text { Highly } \\
\text { restricted }\end{array}$ & $\begin{array}{l}\text { Open with moderate or } \\
\text { slight restrictions }\end{array}$ \\
\hline$[\mathrm{mi}$ & 11ions of acres & (percent of tota 1 & federal land in West)] \\
\hline $\begin{array}{l}\text { Bureau of Land } \\
\text { Management }\end{array}$ & -- & $25.3(7 \%)$ & $143.1(40 \%)$ \\
\hline $\begin{array}{l}\text { U.S. Forest } \\
\text { Service }\end{array}$ & $1.3(<1 \%)$ & $64.6(18 \%)$ & $67.7(19 \%)$ \\
\hline Militarye & $1.1(<1 \%)$ & $13.4(4 \%)$ & $2.3(1 \%)$ \\
\hline $\begin{array}{l}\text { National park } \\
\text { Service }\end{array}$ & $10.9(3 \%)$ & $3.1(1 \%)$ & --- \\
\hline $\begin{array}{l}\text { Bureau of } \\
\quad \text { Reclamationg }\end{array}$ & --- & $6.1(2 \%)$ & --- \\
\hline $\begin{array}{l}\text { Fish and Wildlife } \\
\text { Service }\end{array}$ & -- & $6.5(2 \%)$ & $0.2(<1 \%)$ \\
\hline other ${ }^{i}$ & $8.2(2 \%)$ & $5.0(1 \%)$ & --- \\
\hline Total & $21.5(6 \%)$ & $124.0(35 \%)$ & $213.3(59 \%)$ \\
\hline \multicolumn{2}{|c|}{$\begin{array}{l}\text { Estimate of de facto } \\
\text { withdrawals in West } \\
\text { due to local } \\
\text { administrative } \\
\text { decisions }\end{array}$} & $(+) 13.6(4 \%)$ & $(-) 13.6(4 \%)$ \\
\hline Grand Tota1 & $21.5(6 \%)$ & $137.6(38 \%)$ & $199.7(56 \%)$ \\
\hline
\end{tabular}

ancludes federal land that has never been out of federal ownership (345.5 million acres) and land acquired by the U.S. Government (13.4 million acres), as reported in BLM (1981a, p. 9). This table, and those that follow, do not include lands in which the government owns only the mineral estate. The western states include Washington, Oregon, California, Nevada, Idaho, Hontana, Wyoming, Utah, Colorado, New Mexico, and Arizona.

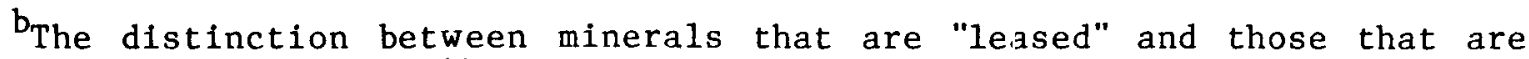
"located" (Table A.4) is more a matter of history than their mode of geologic occurrence. In general, leasable ininerals consist of the fossil fuel, chemical, and fertilizer minerals, as well as geothermal resources. These minerals are disposed of through the Mineral Leasing Act of 1920 and more recent leasing laws that apply to specific minerals 


\section{Table A.3 (continued)}

and areas. Locatable minerals, usually referred to as the hardrock minerals, consist of the metals and other minerals that are not leasable. In genera1, locatable minerals are disposed of under the 1872 Mining Law, except that hardrock minerals are leased on acquired federal land. (Not included with the locatable minerals are common construction materials such as sand, gravel, cinder, pumice, and clay, which are disposed of through the Surface Resources Act of 1955.) For this study, the availability of federal lands for oil and gas leasing generally takes precedence over the availability of these lands for the other leasable minerals. For example, acquired military lands have been assigned to the moderately- or slightly-restricted category because these lands are open to oil and gas leasing, even though they are formally closed or highly restricted for other leasable minerals. Exceptions are noted under each footnote.

$\mathrm{C}_{\text {The BLM }}$ lands in the West total 175 million acres (BLM 1981a), 1.1 million of which have been assigned to the U.S. Fish and Wildlife Service (see footnote $h$ ) and 5.5 million of which are included in the other category, footnote $i$. Thus, the total acreage of BLM land in this row is 168.4 million acres. About 0.5 million of the 25.3 million acres assigned to the highly-restricted category in Table A.3 is due to existing and potential Wild and Scenic Rivers in the West. [The total area in the West affected by the Wild and Scenic Rivers System is about $1,360,000$ acres of federal and nonfederal land, of which 834,160 acres are contained in 18 existing Wild and Scenic Rivers and 524,352 acres are contained in 23 rivers that are currently under study (NPS 1980a, p. 74-77; plus additional information supplied by the NPS-Washington Office). Technica11y, land within 0.25 miles of a designated "wild" river, rather than a "scenic" or "recreational" river segment, is formally withdrawn from mineral leasing and location. Scenic and recreational rivers are open to leasing and location, but mineral activities will rarely be allowed to proceed except under very strict controls. Lands surrounding rivers that are under study for inclusion in the system are withdrawn from location, but not from leasing. For simplicity, and because we do not know the segments of each river that are "wild" and also federally owned (thus formally closed), and because the total acreage involved is relatively small, we have arbitrarily assigned the acreage of all existing and potential Wild and Scenic Rivers to the highly-restricted category under BLM and U.S. Forest Service lands, although some of these lands are not federally owned, and some are administered by other federal agencies such as the National Park Service. The acreage of existing Wild and Scenic Rivers that we assigned to BLM lands in the West is 236,440 acres, whereas 203,264 acres are under study (for a total of about 0.5 million acres). The remaining area of existing and potential Wild and Scenic Rivers (0.90 million acres) is accounted for under U.S. Forest Service lands, footnote d.] The remaining acreage in the highly-restricted category in 
Table A.3 (continued)

the table includes (1) 24.3 million acres of Wilderness Study Areas as of December 1981 [this acreage includes pre-existing Instant Study Areas, Primitive Areas, and Outstanding Natural Areas identified since passage of the Wilderness Act of 1964 (personal communication to E. H. Oakes, December, 1981, Jim Edward, BLM-Washington)]; 2) 482,640 acres in the Snake River Birds of Prey area in Idaho [the Birds of Prey area is not formally closed to leasing, according to the BLM (personal communication to E. H. Oakes, November 1981, Dave A1mond), but, because of its special wildlife habitat, we have assigned it to the highlyrestricted category in Table A.3]; and (3) one wilderness area of slightly more than 12,000 acres. The remaining 143.1 million acres of BLM land in the West are considered to be open to mineral leasing with only moderate or slight restrictions, except for those BLM lands that we estimated to be administratively closed (see footnote $j$ ). [Some reviewers of an earlier draft of this report suggested that the 24.3 million acres of WSAs should have been assigned to the category of moderate or slight restrictions rather than the highly-restricted category because mineral exploration and development have occurred and are still occurring within some WSAs. Furthermore, about 6.5 million acres of WSAs are now under oil and gas lease (personal communication to E. H. Oakes, January 1982, Wilderness Office, BLM-Washington). After reviewing this information, we still chose to assign all WSAs to the highly-restricted category because the BLM is required to protect the wilderness character of WSAs and because, in our opinion, many companies would rather not risk the legal and political battles, and public resentment, that might accompany mineral entry to a WSA. Moreover, if a mineral deposit was discovered in a WSA, its development could conceivably be tied up in the courts for many years--thereby relegating the WSA to the status of effectively closed.

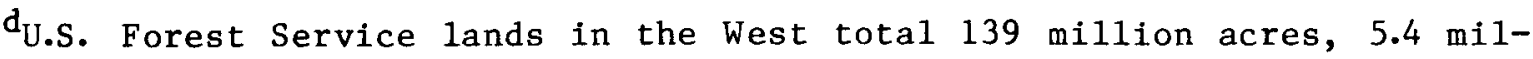
lion of which are included in the other category, footnote $i$. The 1.3 million acres of U.S. Forest Service land assigned to the formally closed category in the table includes four National Recreation Areas (NRAs): Hells Canyon, Sawtooth, Oregon Dunes, and Arapaho (USDA 1980; the remaining 0.4 million acres in NRAs administered by the U.S. Forest Service are within Flaming Gorge and Shasta/Trinity and are tallied below in the highly-restricted category). The 64.6 million acres of U.S. Forest Service land assigned to the highly-restricted category include (1) 0.9 million acres of existing and potential Wild and Scenic Rivers (see footnote $c$, above, for an explanation); (2) 16.6 million acres of existing wilderness (USDA 1980; additional information at bottom of this footnote); (3) 0.4 million acres in NRAs (USDA 1980); (4) 0.7 million acres in game refuges (USDA 1980); (5) 0.004 million acres in scenic/research areas (USDA 1980); (6) 43.3 million acres of RARE-II lands; and (7) 2.7 million acres of primitive areas (the acreage for RARE-II and primitive areas is based on data supplied by the 
Table A.3 (continued)

U.S. Forest Service, "Status of National Forest System Roadless Undeve1oped Lands," as of February 2, 1982). The lands assigned here to the highly-restricted category are so classified because leases will generally not be issued if the mineral activity will significantly impair the scenic, recreational, or natural values that these areas are meant to protect. For example, only 15 oil and gas leases have been issued in existing wilderness areas, although almost 1000 oil and gas lease applications are pending, most of which are in Montana and Wyoming (personal communication to E. H. Oakes, February 26, 1982, Division of Oil andGas, BLM's Washington office; an additional 28 oil and gas leases are in existing wilderness areas, but these leases were issued before the land was designated as wilderness by Congress). [The figure of 43.4 million used in Tables A.3, A.4, and A.5 for RARE-II lands is based on administrative changes on April 16, 1979, to the recommendations in the Final Environmental Statement (USDA 1979) on RARE-II lands. The 43.3 million acres of RARE-II lands in the West include 9.2 million acres recommended for wilderness, 7 million acres recommended for further planning, and 27.1 million acres of recommended nonwilderness RARE-II lands, most of which have yet to be released for multiple-use management and have therefore been assigned to the highly-restricted category (see Table A.5 for the expected future status of these lands). The current status of RARE-II and other undeveloped lands in the Forest Service system is explained in periodic summaries issued by the U.S. Forest Service, the most recent of which was issued on February 2, 1982 (cited above). To avoid confusion, we chose not to include changes such as the recently enacted wilderness bills in Colorado and New Mexico in the RARE-II acreages 1isted above. For Colorado and New Mexico, however, Congress included less RARE-II acreage in the National Wilderness Preservation System than was recommended by the administration in Apri1 1979; thus, the RARE-II acreage figures used in this table are liberal estimates. Also, on February 21, 1982, Interior Secretary James Watt proposed that an 18-year moratorium be placed on all mineral activities in existing wilderness areas. Legally, these wilderness areas are open to mineral exploration and development until December 31, 1983, under provisions in the Wilderness Act of 1964, but will be formally withdrawn from all mineral activities on January 1, 1984. The effect of the proposed moratorium and the effects on the National Wilderness Preservation System of the yet-to-be submitted legislation by the Department of the Interior are not known at this time.]

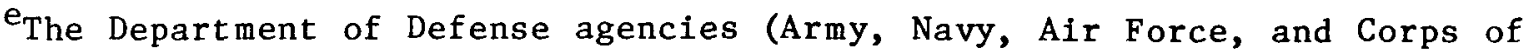
Engineers) administer 16.8 million acres of land in the western United States (BLM 1981a). Of this total, about 2.3 million acres have been acquired by the defense agencies (BLM, 1981a). According to reports in Federal Lands (July 13, 1981), the Reagan administration has lifted a moratorium on oil and gas leasing of acquired military lands. These 2.3 million acres have, therefore, been assigned to the category of 
Tab1e A.3 (continued)

moderately or slightly restricted in Table A.3, although these acquired lands are apparently not available for other leasable minerals (except for geothermal resources on some military lands) or for the locatable minerals that are leased on acquired federal land. About 1.1 million acres under the jurisdiction of the U.S. Army Corps of Engineers are administratively closed to leasing and are listed as such in the table. The remaining 13.4 million acres are 1 isted as highly restricted to mineral activity because the Department of Defense customarily recommends that military lands not be leased because of security and safety reasons (OTA 1979, p. 338). [According to a report in Federa1 Lands (December 14, 1981), the Department of Defense will establish a uniform policy that is expected to increase oil and gas leasing on all military lands.]

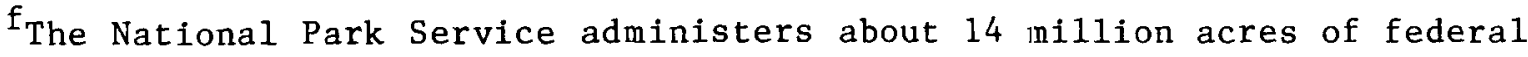
land in the 11 western states, including units such as parks, monuments, recreation areas, historic sites, preserves, seashores, and parkways (NPS 1980a). Most National Park Service lands (except for 3.1 million acres in NRAs, discussed below) are formally closed to mineral activity under the leasing laws, and 10.9 million acres are listed as such in Table A.3. As of December 1980, there was a total of 3.1 million acres in ten NRAs administered by the National Park Service in the West (NPS 1980a). The recreation areas are generally on lands that have been withdrawn for reclamation or water-resource development. Almost all these areas are open by statute to mineral entry, and, although mineral activity does occur on these lands, it is not common. For example, the recent Mineral Management Plan for Glen Canyon National Recreation Area in Utah and Arizona (NPS 1980b) states that mineral activities would be permitted in certain parts of the recreation area if the National Park Service determined that such activities would not significantly affect administration of the recreation area. The authority of the National Park Service to impose strict stipulations on mineral permits and leases justifies inclusion of the 3.1 million acres of NPS National Recreation Areas in the highly-restricted category in Table A.3, although parts of these recreation areas will be open to leasing with only moderate restrictions. (See Table A.4, footnote $f$, for a discussion of new regulations affecting hardrock mining in these recreation areas.)

GLands under the jurisdiction of the Bureau of Reclamation total 6.6 million acres, of which 6.1 million are in the west (BLM 1981a). These lands are generally open to mineral leasing, but with lease stipulations that protect the dominant reclamation use. Moreover, leases will generally not be granted if mineral development would have a significant adverse effect on the recreational uses of the land. Therefore, a11 6.1 million acres of Bureau of Reclamation land are listed under the highly-restricted category in Table A.3. 
Table A.3 (continued)

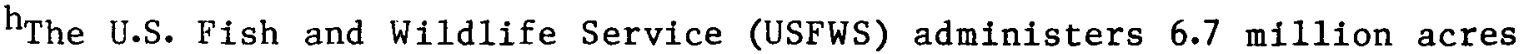
of land in the West. By far, most of this acreage is within national wildlife refuges, but the USFWS also administers other units such as waterfow1 production areas, wildlife monuments, and fish hatcheries (USFWS 1980). In Public Land Statistics (BLM 1981a), the acreage of federal land administered by the USFWS in the West is reported to be 5.6 million acres, rather than the more recent figure of 6.7 million acres reported in USFWS (1980). To account for the additional 1.10million acres of USFWS land since the compilation of data in Public Land Statistics, we have arbitrarily assigned 1.1 million acres of BLM $\overline{1 a n d}$ to the USFWS (see footnote $c$ ). $0 i 1$ and gas leasing of almost all USFWS land in the 48 conterminous states is prohibited except when production on adjacent nonfederal land threatens to drain the oil and gas underlying USFWS lands. Leasing of other minerals is sometimes allowed, but strict lease stipulations are imposed (OTA 1979, p. 344). We have therefore listed all USFWS land as highly restricted to mineral activity in Table A.3, although most of these lands are administratively closed to oil and gas leasing. 0il and gas leasing is permitted, however, on the approximately 0.2 million acres of wildlife coordination areas in the West; this acreage is listed as such in Table A.3 (USFWS 1980).

${ }^{i_{T h e}}$ "Other" category includes 13.2 million acres of federal 1and, 2.3 of which is administered by federal agencies and departments not listed in the table (e.g., the U.S. Department of Energy, the Bureau of Indian Affairs; BLM 1981a, p. 13-33) and 10.9 million of which we have assigned to this category from BLM and U.S. Forest Service lands. (In reality, al1 agencies contribute to this 10.9 million acres, but for simplicity we used 5.5 million acres of BLM land and 5.4 million acres of U.S. Forest Service land; see discussion below.) The 2.3 million acres of western federal land administered by agencies other than the ones listed in Table A.3 are assigned to the formally-closed category in Table A.3, although some of these lands may be available for mineral activities [e.g., leasing of uranium by DOE on some DOE-acquired lands, and oil and gas leasing on the 0.1 million acres of naval petroleum reserves; included with the DOE lands are the three Naval 011 Shale Reserves in Colorado and Utah that total about 0.15 million acres (personal communication to E. H. Oakes, February 1982, James Hemphi11, Office of Naval Petroleum and Oil Shale Reserves, DOE-Washington). The remaining 5.9 million acres assigned to the formally closed category include: (1) nonreservation Indian lands, 0.4 million acres (BLM 1981, Table 9); (2) 2.5 million acres of surface occupancy for federal use by the major land-management agencies [for uses such as buildings, prisons, airports, and post offices; OTA (1979, p. 361) estimated that in 1975 about 1.9 million acres of federal land were used for these purposes in the 48 conterminous states]; (3) 2 million acres for nonfederal use for townships and easements across the public domain [this is an estimate based on data in OTA (1979) and Bennethum and Lee (1975)]; and 
Table A.3 (continued)

(4) 1 million acres withdrawn for watershed protection and water uses [Bennethum and Lee (1975) estimated that 1.5 million acres had been withdrawn for water purposes for the entire country in the mid-1970s. According to BLM (personal communication to $\mathrm{E}$. H. Oakes, December 31, 1981, Withdrawals, Lands, and Rights-of-Way Group), many land withdrawals under Public Water Reserves No. 107 have since been revoked or reduced in size by the Reagan administration. Therefore, the 1 million acres that we assigned to watershed protection and water use in the West is probably overestimated]. The 5 million acres assigned to the highlyrestricted category is a guess as to the acreage of identified powersites in the West. After a power-site has been identified by either the U.S. Geological Survey or by filing an application for a power-site permit or license, the land is automatically withdrawn from mineral development. In 1955, Congress opened to minelal activities all powersite withdrawals and reservations that were not covered by a license or application. However, mineral development on these lands can be terminated by the government at any time for construction of a hydroelectric power station, and no compensation wil.1 be made to the mineral developer; thus, we consider lands in this category to be highly restricted for mineral activities. OTA (1979, p. 357) identified 15.2 million acres that were withdrawn at the end of 1974 because of power-site designations, but 9 million of the 15.2 million acres were in Alaska (the Ramparts power-site on the Yukon River). Thus, about 6.2 million acres of power-sites had been identified by OTA (1979) in the 48 conterminous states. Unfortunately, up-to-date data on power-site withdrawals are not yet available from BLM (persona1 communication to E. H. Oakes, December 31, 1981, Withdrawa1s, Lands, and Rights-of-Way Group). Our estimate of 5 million acres of power-sites in the West represents a liberal estimate based on the belief that many small-scale hydroelectric power-sites (sometimes called "low-head" sites) have been identified since late 1974.

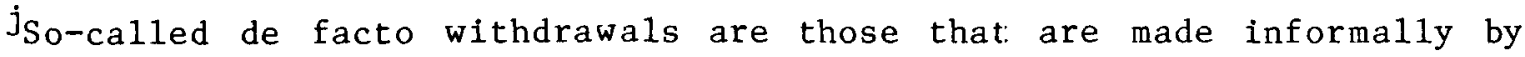
administrative officials at any level within an agency. These withdrawals are the most difficult to identify because they usually are not recorded in an agency's land-status records, nor are they subject to critical review. Many of these withdrawals are the result of environmental assessments, identification of critical habitat for threatened or endangered species (a minor amount of acreage, and these areas are not formally closed), or special recreational and scenic values at a local or reglonal level. In Nevada, for example, GAO (1981a) found that BLM had withdrawn 1.4 million acres of federal land for these reasons, and a few million more were pending additional such as one BLM district closing certain wildlife areas to oil and gas leasing, whereas other districts allowed leasing in simllar environments, but with special lease stipulations. 
Table A.3 (continued)

The only estimate of administrative or de facto land withdrawals that we uncovered is contained in GAO (1981a), and these data were used to estimate the potential magnitude of administrative withdrawals in the 11 western states. In the 48 conterminous states, GAO estimated that 16 million acres of federal land are effectively closed to oil and gas leasing because of administrative withdrawals by various federal agencies (GAO 1981a, p. 29; many of the lands that GAO assigned to the category of administratively withdrawn have been accounted for in our report under the category of highly-restricted). GAO's estimate, however, accounts for only part of the administrative withdrawals by BLM and the U.S. Forest Service because GAO gathered information on these agencies for only five states--Colorado, Mississippi, Nevada, New Mexico, and Wyoming--and the data for Colorado are incomplete (GAO 1981a, p. 50). According to GAO, Nevada had the most reliable data set because of BLM's state-wide environmental assessment program that identified no-leasing areas throughout the state (GAO 1981a, p. 50).

To derive an estimate of the acreage of administrative withdrawals in the West that may not have been accounted for elsewhere in our report, we used the GAO data for New Mexico, Wyoming, and Nevada (GAO, p. 49-55). In New Mexico, GAO identified 84,300 acres as effectively closed to oil and gas leasing due to administrative withdrawals, 80,700 acres of which were closed at the request of BLM. In Wyoming, 800,000 acres were administratively closed, but only 115,000 acres were closed by BLM. The bulk of the Wyoming closures was on U.S. Forest Service lands. In Nevada, 4.7 million acres were closed through administrative action, 3.4 million of which are attributed to BLM. The non-BLM administrative closures in Nevada, amounting to 1.3 million acres, are on U.S. Forest Service lands (largely RARE-II areas), with a minor amount on National Park Service lands. Because we tallied U.S. Forest Service Wilderness Areas and National Park Service lands in other parts of this table (see footnotes $d$ and $f$ ), we used 3.4 million acres as the acreage of federal land in Nevada that is now closed because of administrative withdrawals and that has not been accounted for elsewhere in this table. However, a large part of Nevada's 3.4 mi1lion acres of no-lease land is pending additional environmental study (GAO 1981a, p. 50), and some (perhaps much) of this acreage will become available for oil and gas leasing in the future. Moreover, it is not known with certainty to what extent these 3.4 million acres overlap BLM wilderness study areas or other restricted areas tallied elsewhere in this table.

We speculate that 13.6 million acres of federal land may be effectively closed (highly restricted) by administrative or de facto withdrawals in the 11 western states. This estimate was derived by calculating the percentage of federal lands that are administratively closed in New 
Table A.3 (continued)

Mexico, Wyoming, and Nevada, then multiplying this percentage $(3.8 \%)$ by the total federal acreage in each of the eight remaining western states. Thus, 3.4 million acres in Nevada, out of a total federal acreage in Nevada of 60.5 million, were determined by GAO to be administratively withdrawn from oil and gas leasing, which equals $5.6 \%$ of the federal lands in the state. In Wyoming, 0.8 million acres, or $2.6 \%$ of the total federal acreage, are administratively closed. In New Mexico, 0.08 mil1ion acres, or $0.3 \%$ of the federal acreage in the state, are administratively closed. The total federal domain within the three states is 116.7 million acres, of which 4.3 million, or $3.8 \%$, are effectively closed to oil and gas leasing and therefore are probably closed to leasing of other minerals (see tabulations below). The 13.6 million acres have been subtracted from the acreage in the moderately- or slightly-restricted category on Table A.3 and added to the acreage in the highly-restricted categoy to derive the grand total shown in the table.

Tabulations:

\begin{tabular}{|c|c|c|c|}
\hline State & $\begin{array}{c}\text { Federal acreage }{ }^{a} \\
\text { (millions of acres) }\end{array}$ & & $\begin{array}{l}\text { Estimated administrati } \\
\text { withdrawals (a11 agencies) } \\
\text { (millions of acres) }\end{array}$ \\
\hline Arizona & 32.0 & (x) 0.038 & 1.2 \\
\hline California & 46.7 & (x) 0.038 & 1.8 \\
\hline Colorado & 23.6 & (x) 0.038 & 0.9 \\
\hline Idaho & 33.8 & (x) 0.038 & 1.3 \\
\hline Montana & 27.7 & (x) 0.038 & 1.1 \\
\hline Oregon & 32.3 & (x) 0.038 & 1.2 \\
\hline Utah & 33.5 & (x) 0.038 & 1.3 \\
\hline Washington & 12.5 & (x) 0.038 & 0.5 \\
\hline Subtota 1 & 242.1 & & 9.3 \\
\hline Nevada & 60.5 & & $3.4^{b}$ \\
\hline New Mexico & 25.9 & & $0.1^{b}$ \\
\hline Wyoming & 30.3 & & $0.8^{b}$ \\
\hline Grand Total & 358.9 & & 13.6 \\
\hline
\end{tabular}

\footnotetext{
${ }^{a}$ Source of data: BLM 1981a.

b Source of data: GAO 1981a.
} 
Table A.4. Availability of Federal Onshore Lands in the Western United States $^{a}$ for Locatable Minerals ${ }^{b}$ as of 1981

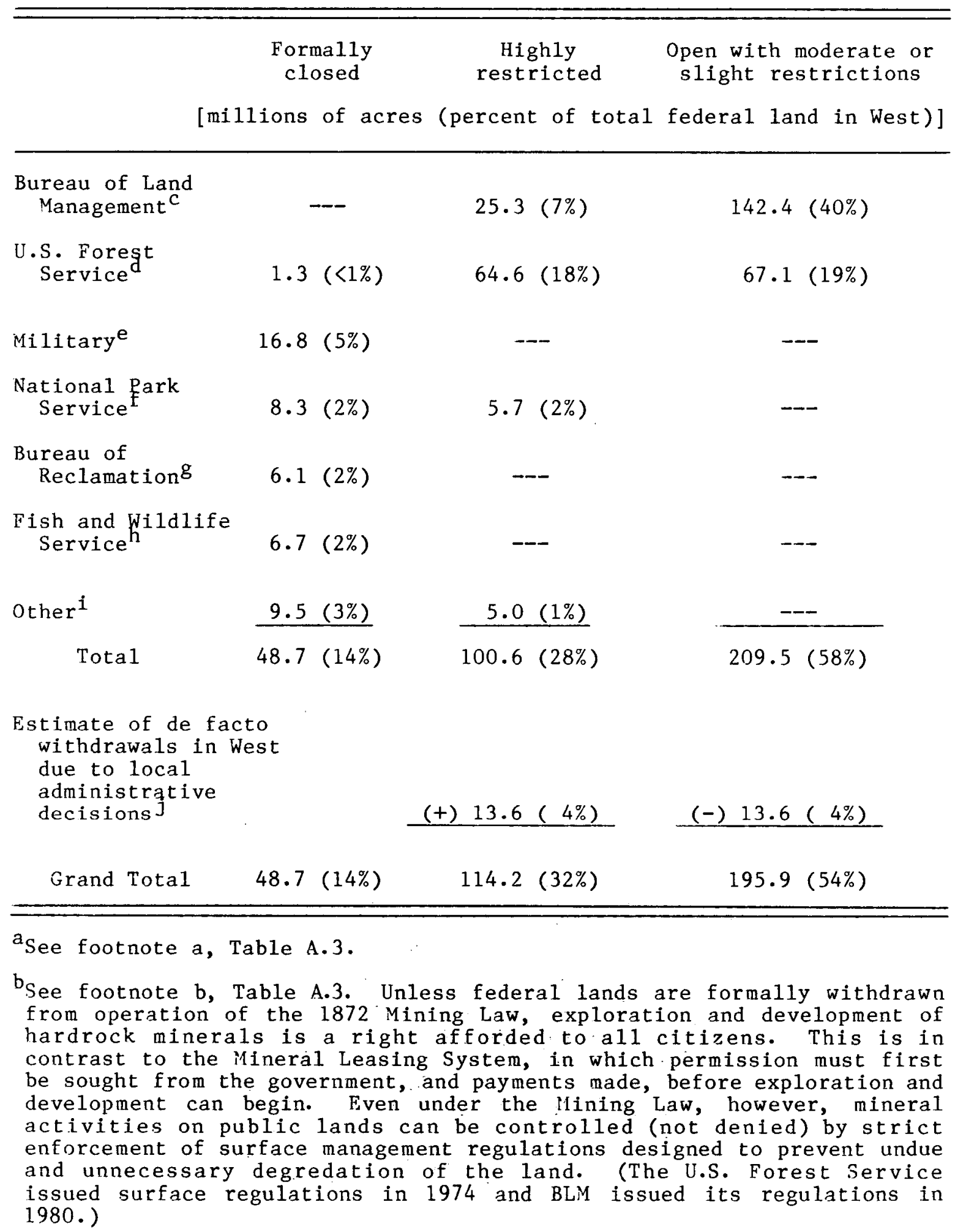


Table A.4 (continued)

${ }^{c}$ See footnote c, Table A.3. We made no changes in the availability of BLM lands for the locatable minerals (compare with Table A.3), but we point out that only 64,845 acres of the total 1.5 million acres in the Birds of Prey area in Idaho are formally closed to hardrock location. See footnote $i$ for additional information.

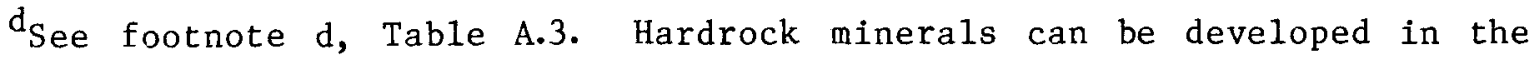
0.4 million acres of national recreation areas administered by the U.S. Forest Service (Flaming Gorge and Shasta/Trinity), but development must be through a leasing system and subject to the consent of the Secretary of Agriculture (OTA 1979, p. 341). We still assigned this acreage to the highly-restricted category because leases are subject to the dominant use, namely reclamation and recreation. See footnote $i$ for additional information.

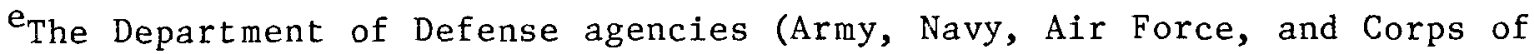
Engineers) administer 16.8 million acres of land in the western United States (BLM 1981a). In general, lands withdrawn for strictly military purposes are essentially, though not formally, closed to mineral activities for safety and security reasons (see footnote e, Table A.3; also OTA 1979 , p. 338). The 16.8 million acres of military lands in the West, including 1.1 million acres under the jurisdiction of the U.S. Army Corps of Engineers, are therefore listed as closed to hardrock mining in this table.

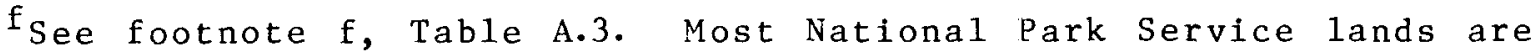
formally closed to mineral activity under the Mining Law. However, the enabling legislation for Crater Lake National Park in Oregon, Mt. McKinley (Denali) National Park and Preserve! in Alaska, and Coronado National Memorial in Arizona has kept these National Park Service units open to mineral location. Moreover, mineral activities in Death Valley National Monument in California and Nevada, Glacier Bay National Park and Preserve in Alaska, and Organ Pipe Cactus National Monument in Arizona were reinstated after their formal designation as National Park Service units (GAO 1981b). In 1976, after Congress passed the Mining in the Parks Act (PL 94-429), mineral entry in these six National Park Service units was prohibited, and strict provisions were imposed on existing mineral activities (which occur largely in Death Valley for talc and borate minerals). The total area of these parks and monuments in the West is 2.6 million acres (NPS 1980a). Because the National Park Service genera1ly discourages mineral activities in all its units, the 2.6 million acres are listed under the highly-restricted category. The remaining 3.1 million acres assigned to the highly-restricted category are within four national recreation areas (see footnote $\mathrm{f}$, Table A.3 for more information). According to reports in Federal Lands December 12, 1981) these recreation areas have recently been opened to hardrock mining. We still chose to assign these lands to the high1y-restricted 
Table A.4 (continued)

category because BLM will require the consent of the regional director of the National Park Service before a mineral permit is granted. If, or when, faced with this decision, we believe that there would be considerable public pressure not to issue these mineral permits. Furthermore, even if mineral permits are granted, special stipulations can be imposed to avoid unnecessary harm to the environment, thereby tending to discourage mineral activities.

g Lands under the jurisdiction of the Bureau of Reclamation total 6.6 million acres, of which 6.1 million are in the west (BLM 1981a). The Department of the Interior considers all lands withdrawn for reclamation purposes to be closed to location under the Mining Law, and the entire 6.1 million acres are listed as such in the table (OTA 1979, p. 355).

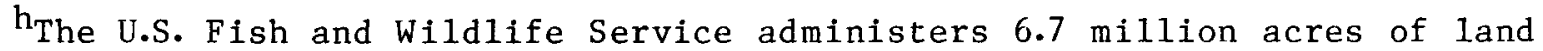
in the West. Most lands controlled by the U.S. Fish and Wildlife Service are formally closed under the Mining Law (O'TA 1979, p. 355). As of 1981, however, a few wildlife and game ranges were still under application for withdrawal under the Mining Law (personal communication to E. H. Oakes, January 25, 1982, U.S. Fish and Wildlife Service). Until a decision is made, these lands are managed as formally closed to mineral location. The entire acreage controlled by the Fish and Wildife Service in the West is therefore listed in this table as formally-closed to mineral location.

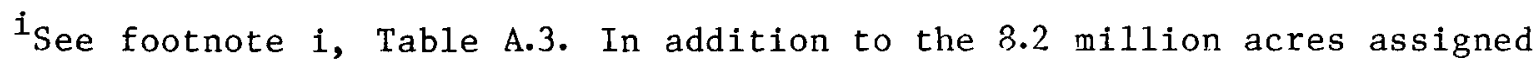
to the formally closed category in Table A.3 (which are also assigned to this category in Table A.4), certain public lands have been classified and removed chiefly from operation of the Mining Law as a result of the Smal1 Tract Act of 1938 (repealed in 1976), the Recreation and Public Purposes Act of 1926, and the Classification and Multiple Use Act of 1964. As of October 16, 1981, about 1.3 million acres of public land in the West had been so classified; this area has been added to the 8.2 million acres to arrive at the total 9.5 million acres indicated in this table (written communication to E. H. Oakes, December 1981, BLM's Withdrawa1s, Lands, and Rights-of-Way Group). To account for this acreage, we arbitrarily used 0.7 million acres of BLM 1 and and $0.6 \mathrm{mil}-$ lion acres of U.S. Forest Service land; thus, the total acreage of BLM and Forest Service land in this table is less than that shown in Table A.3).

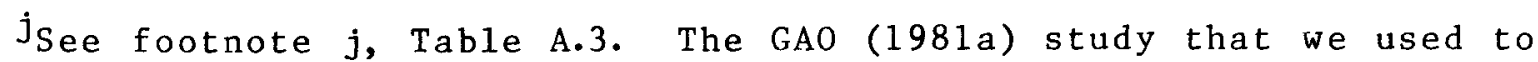
calculate our estimate of administrative withdrawals in the West is based on restrictions to oil and gas leasing--not mineral location. Nevertheless, administrative decisions that restrict or prohibit leasing can also be used to effectively prevent or delay development of hardrock 
Table A.4 (continued)

minerals by enforcing (or threatening to enforce) strict surfacemanagement regulations. Therefore, it seems reasonable to assume that many areas that have been closed administratively to mineral leasing will also be highly restricted for hardrock activities. Thus, we have used the 13.6 million acres derived in Table A.3, footnote $j$, as the acreage of federal land in the West that is highly restricted at the present time for hardrock exploration and mining, although this is probably a liberal estimate. 
Table A.5. Estimated Future (1990) Availability of Onshore Federa1 Lands in the Western United States for Mineral Activities ${ }^{a}$

\begin{tabular}{|c|c|c|c|}
\hline & $\begin{array}{l}\text { Formally } \\
\text { closed }\end{array}$ & $\begin{array}{l}\text { Highly } \\
\text { restricted }\end{array}$ & $\begin{array}{l}\text { Open with moderate or } \\
\text { slight restrictions }\end{array}$ \\
\hline & lions of acr & (percent of $t$ & tal federal land in West)] \\
\hline \multicolumn{4}{|l|}{ Bureau of Land } \\
\hline \multicolumn{4}{|l|}{ Management ${ }^{d}$} \\
\hline Leasable & $6.5(2 \%)$ & $6.6(2 \%)$ & $155.3(43 \%)$ \\
\hline Locatable & $6.5(2 \%)$ & $6.6(2 \%)$ & $154.0(43 \%)$ \\
\hline \multicolumn{4}{|l|}{ U.S. Forest } \\
\hline \multicolumn{4}{|l|}{ Service ${ }^{c}$} \\
\hline Leasable & $32.3(9 \%)$ & $6.5(2 \%)$ & $94.8(26 \%)$ \\
\hline Locatable & $32.3(9 \%)$ & $6.5(2 \%)$ & $94.8(26 \%)$ \\
\hline \multicolumn{4}{|l|}{ Military } \\
\hline Leasable & $1.1(<1 \%)$ & $13.4(4 \%)$ & $2.3(1 \%)$ \\
\hline Locatable & $16.8(5 \%)$ & --- & $-\infty$ \\
\hline \multicolumn{4}{|l|}{ National Park } \\
\hline \multicolumn{4}{|l|}{ Service ${ }^{\mathrm{e}}$} \\
\hline Leasable & $10.9(3 \%)$ & $3.1(1 \%)$ & -- \\
\hline Locatable & $8.3(2 \%)$ & $5.7(2 \%)$ & -- \\
\hline \multicolumn{4}{|l|}{ Bureau of } \\
\hline Leasable & --- & $6.1(2 \%)$ & -- \\
\hline Locatable & $6.1(2 \%)$ & --- & -- \\
\hline \multicolumn{4}{|c|}{ Fish and Wildlife } \\
\hline Leasable & -- & $6.5(2 \%)$ & $0.2(<1 \%)$ \\
\hline Locatable & $6.7(2 \%)$ & $-\infty$ & -- \\
\hline \multicolumn{4}{|l|}{ other ${ }^{h}$} \\
\hline Leasable & $4.2(1 \%)$ & $5.0(1 \%)$ & $4.0(1 \%)$ \\
\hline Locatable & $5.5(2 \%)$ & $5.0(1 \%)$ & $4.0(1 \%)$ \\
\hline Total & & - & \\
\hline Leasable & $55.0(15 \%)$ & $47.2(13 \%)$ & $256.6(72 \%)$ \\
\hline Locatable & $82.2(23 \%)$ & $23.8(7 \%)$ & $252.8(70 \%)$ \\
\hline
\end{tabular}


Table A.5 (continued)

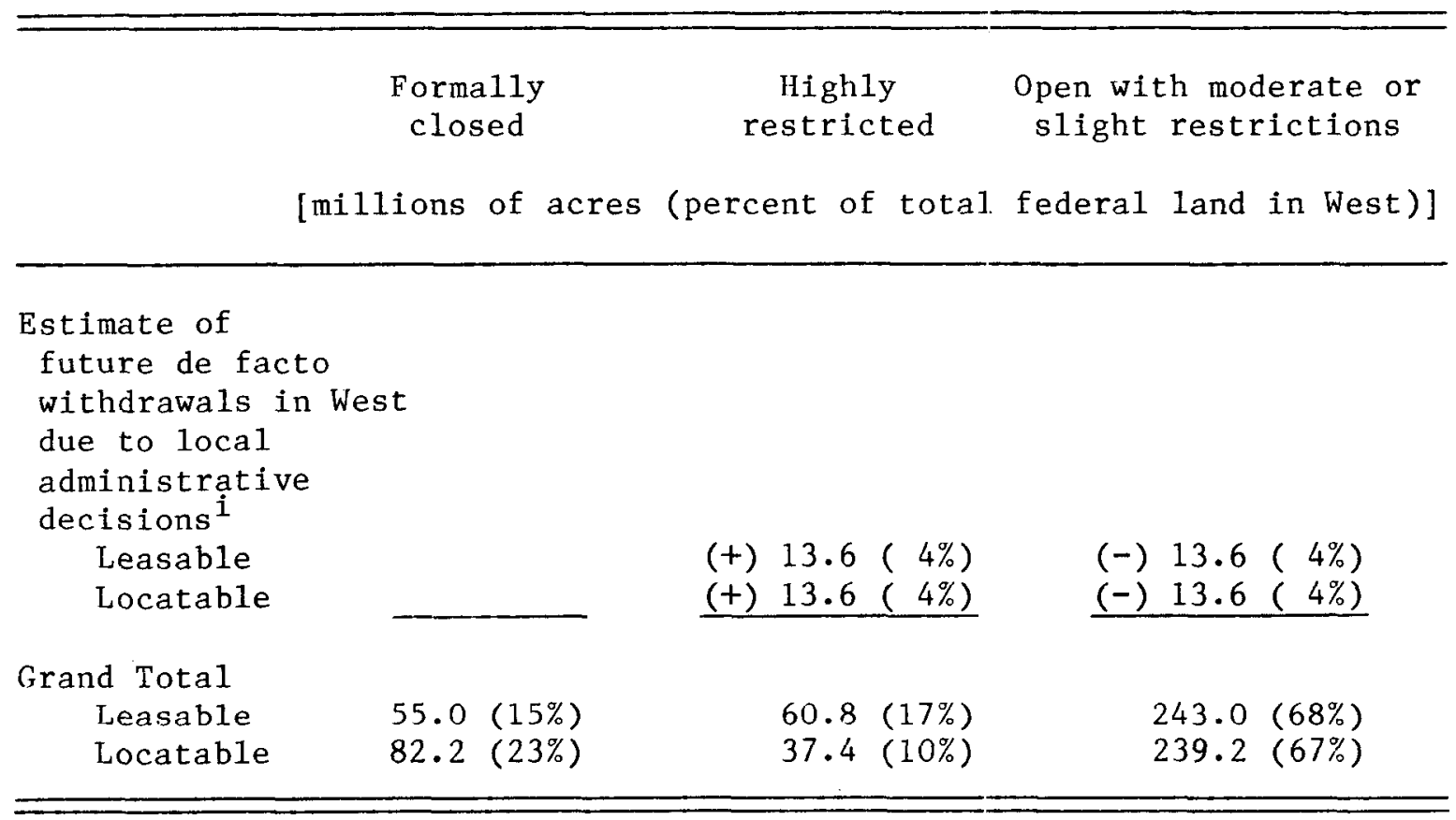

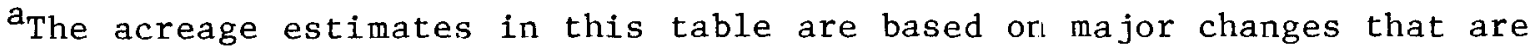
expected to occur during the next 10 years--particularly the termination of national land-use planning programs within the BLM and U.S. Forest Service. The cumulative acreage of additional withdrawals of federal land during the next 10 years is difficult to predict with confidence. Nevertheless, some trends are apparent, and this table is an attempt to quantify these trends to the extent that the data allow. [Note: the area of federal land in the West in 1990 is assumed to be 358.8 million acres--the same as in fiscal year 1979 (BLM 1981a)--despite changes that will no doubt reduce this acreage. Large and unforeseen changes, such as selling excess federal land to balance the budget, are not considered in this table.]

bAssignment of $6.5 \mathrm{million}$ acres of BLM land to the formally closed category for the leasable and locatable minerals assumes that $25 \%$ of the 24.3 million acres of currently identified WSAs ( 6.1 million acres) will be designated as wilderness by Congress. Based on provisions in the Wilderness Act of 1964, wilderness areas will be withdrawn from all mineral activities after December 31, 1983 (proposed extensions and moratoriums to this deadline are not considered). This estimate also assumes that Congress will act on these WSAs before the 1993 deadline set in the Federal Land Policy and Management Act of 1976 (BLM has indicated that it is planning to complete the wilderness review program by 1987). The remaining 0.4 million acres in the formally closed category are attributed to Wild and Scenic Rivers. For this estimate we have assumed that by 1990 the rivers now under study in the West will 
Table A.5 (continued)

be included in the system (see footnote $c$, Table A.3, for more information). The 6.6 million acres of BLM land in the highly-restricted category is based on an assumption that $25 \%$ of the currently identified WSAs (6.1 million acres) will be included in a further-planning category in 1990 and managed in a highly restrictive manner. The remaining 0.5 million acres in the highly-restricted category are accounted for by the Birds of Prey area in Idaho. The remaining BLM lands for both the leasable and locatable minerals, less a few million acres accounted for elsewhere (see footnotes $g$ and $h$ below), are considered to be open in 1990 with moderate or slight restrictions.

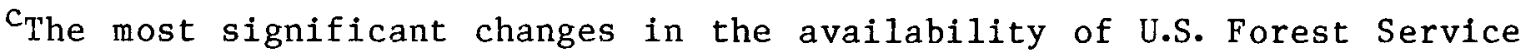
lands expected during the next 10 years are (1) the release of 27.1 million acres of RARE-II lands in the West that have been recommended for nonwilderness, (2) the release for nonwilderness use of some part of the 7 million acres of RARE-II further planning areas (see footnote d, Table A.3 for an explanation of the assumptions used for RARE-II lands), and (3) the formal withdrawal (after December 31, 1983) of all wilderness areas from operation of the mineral laws. The 32.3 million acres of U.S. Forest Service land assigned to the formally-closed category in 1990 for leasable and locatable minerals include (1) 29.3 million acres of designated wilderness [derived as follows (see footnote d, Table A.3, for additional details): 16.6 million acres of currently existing wilderness, 9.2 million acres of RARE-II recommended wilderness, 3.5 million of the 7 million acres of RARE-II further planning areas], and (2) an estimated 3 million acres in national recreation areas (see footnote d, Table A.3) and additional Wild and Scenic Rivers. The 6.5 million acres in the highly-restricted category include research areas, game refuges, some Wild and Scenic Rivers still under study in 1990, and national recreation areas (compare with Tables A.3 and A.4). The remaining U.S. Forest Service acreage for both the leasable and locatable minerals, less a few million acres accounted for elsewhere (see footnotes $\mathrm{g}$ and $\mathrm{h}$ below), is considered to be open in 1990 with moderate or slight restrictions.

$\mathrm{d}_{\mathrm{No}}$ significant changes are foreseen (see Tables A.3 and A.4). According to a report in Federal Lands (December 14, 1981), the Department of Defense will establish a uniform policy for oil and gas leasing on military lands. This policy is expected to increase the acreage of military land to be leased in the future, but details of the policy are not yet known, and its effectiveness if implemented is questionable.

$\mathrm{e}_{\mathrm{No}}$ significant changes are expected (see Tables A.3 and A.4).

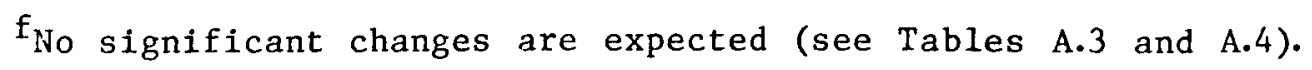

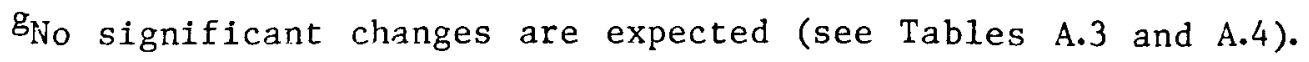


Table A.5 (continued)

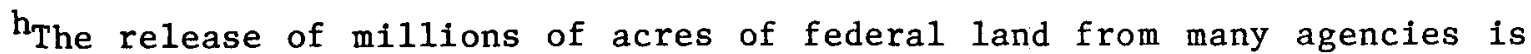
expected during the next few years. According to BLM (personal communication to E. H. Oakes, October 1981, Withdrawals, Lands, and Rights-ofWay Group), since the Reagan administration took office, withdrawal orders affecting tens of millions of acres of federal land throughout the country have been revoked. However, not all these acres immediately become available for mineral activities because most of these lands have overlapping withdrawals. Of the acreage in Tables A.3 and A.4 that we assigned to this category in the West for leasable and locatable minerals, we speculate that 4.0 million will be effectively available under the two mineral disposal systems by 1990 (see this table, moderate and slight restrictions).

iour estimate of administrative or de facto withdrawals in the West is explained in Table A.3, footnote $j$. We decided not to change the acreage estimate for this table because, in the future, land-management agencies at the local level will probably continue to withdraw federal land from mineral activities for environmental purposes such as wildlife habitat, recreational uses, and scenic values. On the other hand, the Reagan administration has made clear its intent to make more federal land available for mineral activities. Local land managers must necessarily take this philosophy into account when justifying existing administrative withdrawals, as well as when arguing for additional withdrawals. 


\section{CONCLUSTONS AND RECOMMENDATIONS}

The results of this study indicate that roughly $45 \%$ of the West's federal land is now effectively closed to mineral activities. Most of the restrictions are the result of environmental and/or aesthetic concerns and include potential and existing wilderness areas, and lands administered by the National Park Service and U.S. Fish and Wildlife Service. A smaller percentage of the restrictions is attributed to military lands, mineral reserves, and lands used for reclamation and recreation. As the major land-management agencies complete their wilderness/land-use inventories over the next 10 years, the availability of federal land in the West will increase to almost 70\%. We therefore recommend that the current administration support the established procedures of the land-review programs, but accelerate the review process for regions in the West that have a high mineral-resource potential. Whether the $30 \%$ of the West's federal land that will remain withdrawn in 1991 is excessive is a matter for the public and the Congress to decide. 


\section{REFERENCES FOR APPENDIX}

AIPG, 1981, Metals, minerals, mining: American Institute of Professional Geologists, Golden Colorado, 36 p.

Bennethum and Lee, 1975, "Is our account overdrawn?": Mining Congress Journal, September 1975, p. 43-48.

BLM, 1979, Interim management policy and guidelines for lands under wilderness review: U.S. Department of the Interior, Bureau of Land Management, $32 \mathrm{p}$.

BLM, 1981a, Public land statistics--1979: U.S. Department of the Interior, Bureau of Land Management, 183 p.

BLM, $1981 \mathrm{~b}$, Wilderness management policy: J.S. Department of the Interior, Bureau of Land Management, September 24, 1981, 36 p.

DOI, 1976, Mining and minerals policy--Annual report to the Secretary of the Interior under the Mining and Minerals Policy Act of 1970: Superintendent of Documents, U.S. Government Printing Office, Washington, D.C.

DOI, 1977, Final report of the task force on the availability of federally owned mineral lands: Superintendent of Documents, U.S. Government Printing Office, Washington, D.C., 103 p.

EPC, et a1., 1981, Minerals and the public lands--An analysis of strategic minerals issues and public lands folicy: A joint publication by the Environmental Policy Center, Friends of the Earth, National Audubon Society, National Wild1ife Federation, Natural Resources Defense Council, Sierra Club, and the Wilderness Society, October 1981, 105 p.

GAO, 1981a, Actions needed to increase federal onshore oil and gas exploration and development: General Accounting Office, EMD-81:40, February 11, 1981, 203 p.

GAO, 1981b, Mining on National Park Service lands--What is at stake?: General Accounting Office, EMD-81-119, September 24, 1981, 50 p.

Jackson, R.H., 1981, Land use in America: John Wiley \& Sons, New York, 226 p. 
NPS, 1980a, Index of Nationa1 Park System and related areas as of June 30, 1979 (including updates through December 1980): National Park Service, Washington, D.C., 96 p. (available from U.S. Government Printing office, Washington, D.C.).

NPS, 1980b, Mineral management plan, March 1980, Glen Canyon National Recreation Area, Arizona-Utah: Available from National Park Service, Glen Canyon National Recreation Area, Page, Arizona, 35 p.

OTA, 1976, Minera1 accessibility on federa1 lands--Interim Report: Office of Technology Assessment, Congress of the United States, U.S. Government Printing office, Washington, D.C.

OTA, 1979, Management of fuel and nonfuel minerals in federal lands-Current status and issues: Office of Technology Assessment, Congress of the United States, U.S. Government Printing Office, Washington, D.C. 435 p.

Sheridan, David, 1977, Hard rock mining on the public lands: Council of Environmental Quality, 37 p. (Available from U.S. Government Printing Office, Washington, D.C.).

USDA, 1979, Final environmental statement, roadless area review and evaluation--RARE-II: U.S. Department of Agriculture, Forest Service (Available from the Superintendent of Documents, U.S. Government Printing office, Washington, D.C.).

USDA, 1980, Land areas of the National Forest System: U.S. Department of Agriculture, Forest Service, FS-360, 77 p.

USFWS, 1980, Annual report of lands under control of the U.S. Fish and Wildlife Service as of September 30, 1980: Division of Realty, U.S. Fish and Wildlife Service, $24 \mathrm{p}$. 
ORNL/TM-8310

\section{INTERNAL DISTRIBUTION}

1. E. D. Aebischer

2. S. I. Auerbach

3. D. Bjornstad

4. R. M. Davis

5. J. E. Dobson

6. W. Fulkerson

7. E. L. Hillsman

8. B. F. Hobbs

9. R. B. Honea

10. R. Lee

11. A. L. Lotts

12. L. B. Maudl in

13. D. 01 son

14. D. C. Parzyck
15. C. H. Petrich

16. D. E. Reichle

17. T. H. Row

18. R. B. Shelton

19. J. W. Sims

20. J. H. Sorensen

21-135. A. H. Voelker

136. T. J. Wilbanks

137. A. Witten

138. Central Fesearch Library

139. Document Reference Section

140-141. Laboratory Records

142. Laboratory Records (RC)

143. ORNL Patent Office

\section{EXTERNAL DISTRIBUTION}

144-308. Regional and Urban Studies Distribution List, Energy Division

309. Office of Assistant Manager for Energy Research and Development, Department of Energy, Oak Ridge Operations Office, Oak Ridge, TN 37830

310-336. Technical Information Center, Department of Energy, P.0. Box 62, Oak Ridge, TN 37830

337-341. E. Oakes, Science Applications, Inc., 800 0ak Ridge Turnpike, P.0. Box 843, Oak Ridge, TN 37830

342. Helmuth Wedow, Jr., P.0. Box 11542, Knoxville, Tennessee 37919 